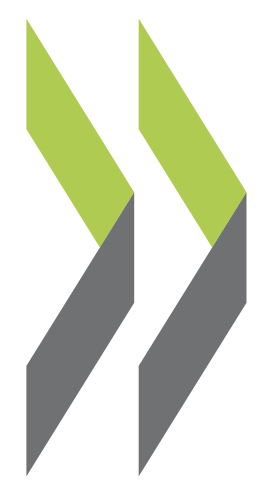

OECD Economics Department Working Papers No. 1568

$$
\begin{array}{r}
\text { Labour market reform } \\
\text { in Japan to cope with } \\
\text { a shrinking and ageing } \\
\text { population }
\end{array}
$$

\section{Randall S. Jones,}

Haruki Seitani 


\section{ECONOMICS DEPARTMENT}

\section{LABOUR MARKET REFORM IN JAPAN TO COPE WITH A SHRINKING AND AGEING POPULATION}

\section{ECONOMICS DEPARTMENT WORKING PAPERS No. 1568}

\section{By Randall S. Jones and Haruki Seitani}

OECD Working Papers should not be reported as representing the official views of the $O E C D$ or of its member countries. The opinions expressed and arguments employed are those of the author(s).

Authorised for publication by Isabell Koske, Deputy Director, Country Studies Branch, Economics Department

All Economics Department Working Papers are available at www.oecd.org/eco/workingpapers.

JT03451054 
OECD Working Papers should not be reported as representing the official views of the OECD or of its member countries. The opinions expressed and arguments employed are those of the author(s).

Working Papers describe preliminary results or research in progress by the author(s) and are published to stimulate discussion on a broad range of issues on which the OECD works.

Comments on Working Papers are welcomed, and may be sent to the Economics Department, OECD, 2 rue André-Pascal, 75775 Paris Cedex 16, France, or by e-mail to econ.contact@oecd.org.

All Economics Department Working Papers are available at www.oecd.org/eco/workingpapers.

This document and any map included herein are without prejudice to the status of or sovereignty over any territory, to the delimitation of international frontiers and boundaries and to the name of any territory, city or area.

The statistical data for Israel are supplied by and under the responsibility of the relevant Israeli authorities. The use of such data by the OECD is without prejudice to the status of the Golan Heights, East Jerusalem and Israeli settlements in the West Bank under the terms of international law.

C OECD (2019)

You can copy, download or print OECD content for your own use, and you can include excerpts from OECD publications, databases and multimedia products in your own documents, presentations, blogs, websites and teaching materials, provided that suitable acknowledgment of OECD as source and copyright owner is given. All requests for commercial use and translation rights should be submitted to rights@oecd.org 


\section{ABSTRACT/RÉSUMÉ}

\section{Labour market reform in Japan to cope with a shrinking and ageing population}

Fundamental reform of traditional Japanese labour market practices is essential to cope with rapid population ageing and the era of 100-year lives. A shift to more flexible employment and wage systems based on performance rather than age would enable Japan to better utilise its human capital. Abolishing the right of firms to set mandatory retirement - typically at age 60 - would enable employees to extend their careers and reduce the link between wages and seniority. It would also facilitate a further increase in the pension eligibility age above 65 , thereby helping to reduce poverty among the elderly. Life-long learning is another key element to extending careers. It is also crucial to address a range of issues that discourage the employment of women, namely the lack of work-life balance and shortages of high quality and affordable childcare and long-term care for the elderly. Fighting discrimination and gender stereotypes is also important to allow women to assume greater leadership roles. Coping with population decline also requires pursuing recent efforts to increase the role of foreign workers in Japan. Breaking down labour market dualism is crucial to expand employment opportunities for women and older people, while reducing income inequality and relative poverty.

This Working Paper relates to the 2019 OECD Economic Survey of Japan

(http://www.oecd.org/economy/japan-economic-snapshot/)

\section{JEL classification: J2, J3, J7, J8}

Keywords: Japanese economy, labour market, labour shortages, labour force participation, population ageing, older workers, mandatory retirement, pension eligibility age, lifelong learning, female employment, work-life balance, childcare, womenomics, foreign workers, dualism, non-regular workers.

\section{Réforme du marché du travail au Japon pour faire face à la diminution et au vieillissement de la population}

Une réforme en profondeur des pratiques traditionnelles du marché du travail japonais est essentielle pour faire face au vieillissement rapide de la population et à une époque où l'on peut espérer vivre jusqu'à 100 ans. Un changement de cap vers des formes d'emploi et des systèmes de salaires plus flexibles, reposant davantage sur les aptitudes et moins sur l'âge, permettrait au Japon de faire un meilleur usage de son capital humain. Abolir le droit des entreprises de fixer la retraite obligatoire - généralement à 60 ans - permettrait aux employés de prolonger leur carrière et réduirait le lien entre salaire et ancienneté. Cela faciliterait également une nouvelle augmentation de l'âge d'ouverture des droits à pension au-delà de 65 ans, contribuant ainsi à réduire la pauvreté chez les personnes âgées. L'apprentissage tout au long de la vie est un autre élément clé pour prolonger les carrières. Il est également crucial de s'attaquer aux problèmes qui dissuadent des femmes d'exercer une activité, notamment par le manque d'équilibre entre vie professionnelle et vie privée et par les pénuries de services de garde d'enfants de qualité et abordables et celles de soins de longue durée pour les personnes âgées. Afin de permettre aux femmes d'assumer davantage de postes de direction, il importe également de lutter contre la discrimination et contre les stéréotypes liés au sexe. Il est nécessaire aussi de renforcer le rôle des travailleurs étrangers au Japon pour faire face au déclin de la population. Il est également crucial de mettre fin au dualisme du marché de l'emploi pour élargir les possibilités d'emploi des femmes et des personnes âgées, tout en réduisant les inégalités de revenus et la pauvreté relative.

Ce Document de travail a trait à l'Étude économique de l'OCDE du Japon, 2019

(http://www.oecd.org/fr/economie/nouvelle-zelande-en-un-coup-d-oeil/).

Classification JEL : J2, J3, J7, J8

Mots clés : Marché du travail, pénuries de main-d'œuvre, vieillissement de la population, travailleurs âgés, âge obligatoire de la retraite, l'âge d'ouverture des droits à pension, activité des femmes, équilibre vie

professionnelle-vie privée, womenomics, travailleurs étrangers, dualisme, travailleurs non réguliers. 


\section{Table of Contents}

Labour market reform in Japan to cope with a shrinking and ageing population .......................... 6

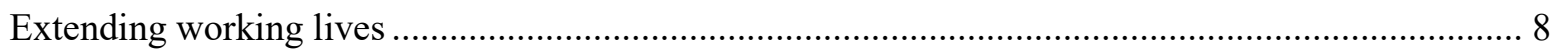

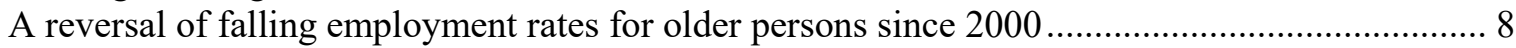

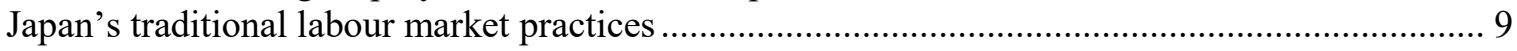

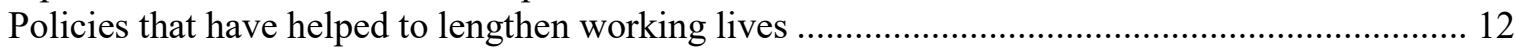

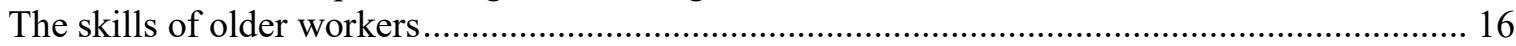

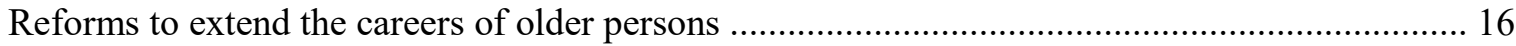

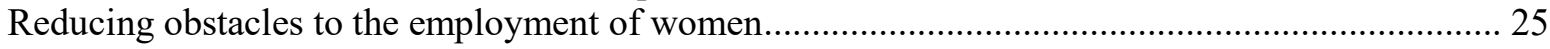

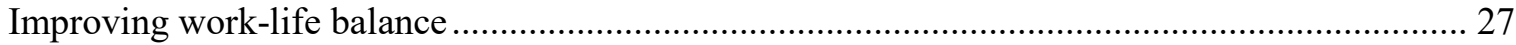

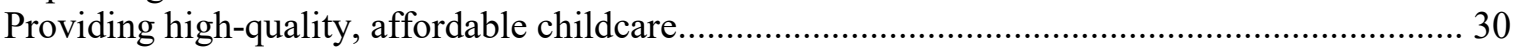

Ensuring that women do not have to leave their jobs to care for elderly relatives.......................... 33

Reforming the tax system to remove disincentives to work for second earners ............................ 33

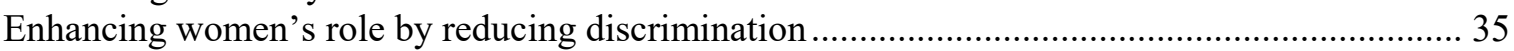

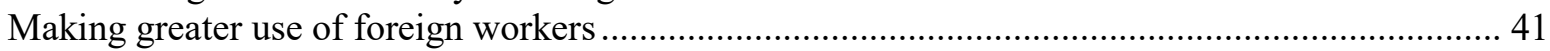

Promoting inclusive growth by breaking down labour market dualism ......................................... 44

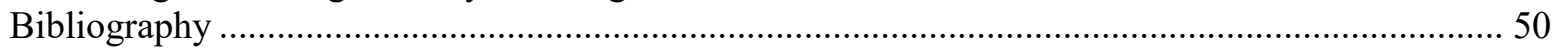

\section{Tables}

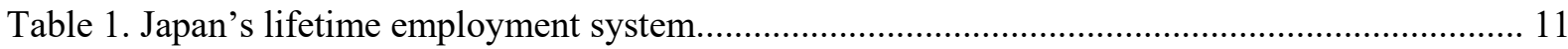

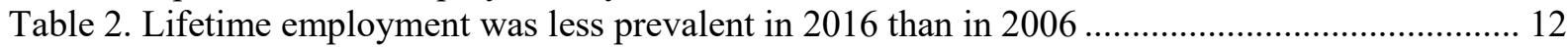

Table 3. Measures affecting the employment of older persons ............................................................ 14

Table 4. Raising the pensionable age leads to a large increase in the replacement rate ........................ 20

Table 5. Targets set in the 2015 Fourth Basic Plan for Gender Equality ............................................. 36

No table of figures entries found.

No table of figures entries found.

\section{Figures}

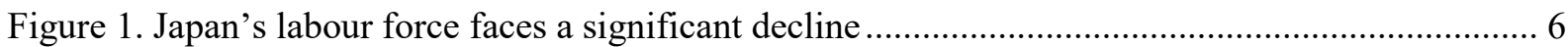

Figure 2. The employment rate of older persons in Japan has been trending up .................................. 8

Figure 3. Older Japanese have relatively high employment rates ....................................................... 9

Figure 4. The seniority-based wage system in Japan remains strong ................................................. 10

Figure 5. The link between tenure and wages in Japan is one of the strongest in the OECD .............. 10

Figure 6. The rise in the employment rate is linked to hikes in the pension eligibility age .................. 13

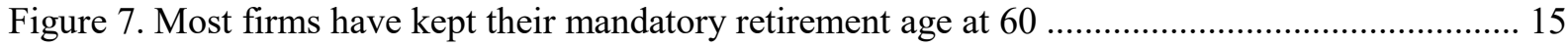

Figure 8. Many workers become non-regular employees after reaching the age of $60 \ldots \ldots \ldots \ldots \ldots \ldots \ldots \ldots . . . . . . .15$

Figure 9. Older workers' use of skills at work in Japan is relatively low ........................................... 17

Figure 10. Skills of older workers in Japan are well below those of younger workers ......................... 18

Figure 11. The projected replacement rate of Japan's public pension system is low ............................. 19

Figure 12. Participation in job-related training is low for older Japanese ............................................ 23 
Figure 13. Share of workers who find education and training useful for their job is low in Japan....... 24

Figure 14. Reasons why some inactive persons who wish to work do not search for jobs ................... 25

Figure 15. Dual-income households now account for two-thirds of all households ............................. 25

Figure 16. Female employment has increased, but gender inequality remains high ............................ 26

Figure 17. Working hours in Japan have changed little during the past 30 years ............................... 28

Figure 18. Long working hours in Japan have negative consequences .............................................. 29

Figure 19. The share of women remaining in the labour force after having children ........................... 31

Figure 20. Waiting lists remain long despite rising childcare capacity ............................................... 32

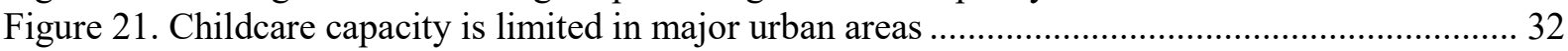

Figure 22. The number of workers leaving jobs in Japan to provide long-term care is rising .............. 34

Figure 23. The spousal deduction negatively affects female labour participation and equality............ 35

Figure 24. Average tax rates tend to be higher on second earners than on individuals ......................... 36

Figure 25. Japanese women are under-represented in leadership positions ........................................ 37

Figure 26. Japanese women are under-represented in certain areas of study and professions .............. 39

Figure 27. The impact of education and tenure on the share of women in management ..................... 40

Figure 28. The share of the foreign-born population in Japan is one of the lowest in the OECD........ 42

Figure 29. Non-regular employment is concentrated among women.................................................. 45

Figure 30. The wage gap between regular and non-regular workers is large ........................................ 46

Figure 31. Japan has relatively strong employment protection for regular workers ............................ 48

\section{Boxes}

Box 1. The current framework for foreign workers in Japan 


\title{
Labour market reform in Japan to cope with a shrinking and ageing population
}

\author{
By Randall S. Jones and Haruki Seitani ${ }^{1}$
}

Population ageing entails significant opportunities and challenges for individuals, firms and governments. Being a front-runner in ageing gives Japan some important advantages in terms of developing new business opportunities and technologies to cope with labour shortages. Japan's working-age population (20 to 64) peaked in 1998 and has been falling more than $1 \%$ per year since 2012 . The unemployment rate has remained below $3 \%$ since 2017 and the job openings-to-applicants ratio has been around 1.6 since May 2018, the highest since the 1970s. Even for regular workers, the ratio exceeds one. More than $80 \%$ of firms surveyed in a 2017 poll reported that they expect labour shortages will force them to restrict the number of services they can offer over the next few years (Reuters, 2017). Already, Japan Post plans to end Saturday mail delivery, joining others in the logistics industry that are curtailing services. A survey of 10000 firms by the Teikoku Data Bank in 2018 found that half reported a lack of labour and 70 went bankrupt in the first half of the year due to labour shortages (Martinez, 2018).

Figure 1. Japan's labour force faces a significant decline

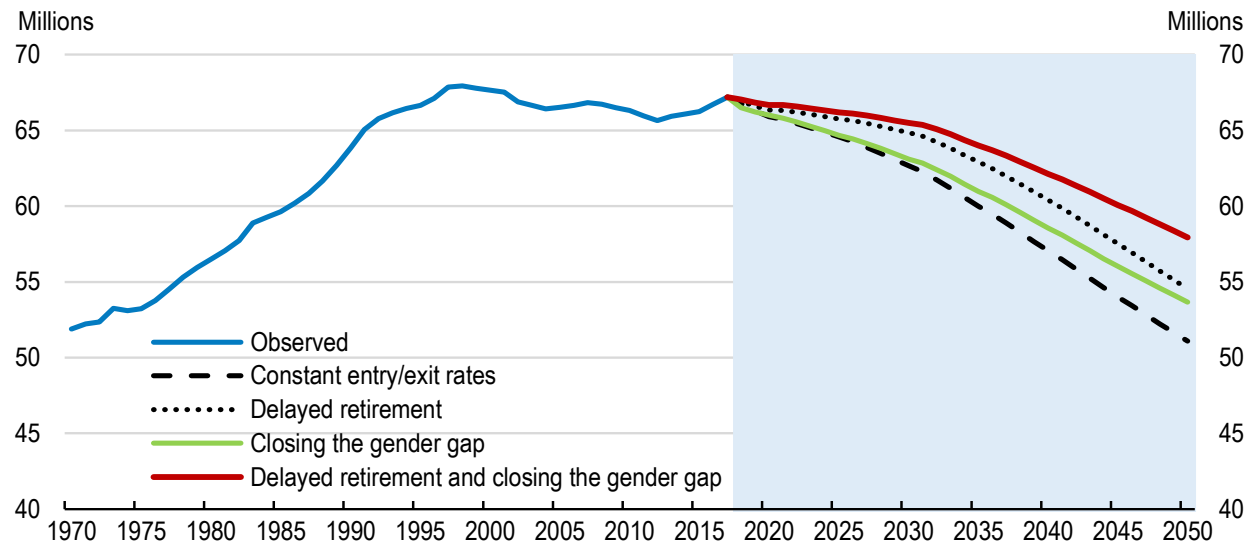

Note: The baseline assumes constant labour market entry and exit rates by gender and five-year age groups. In the "delayed retirement scenario", exit rates are reduced for both men and women by $10 \%$ for each five-year age group between the ages 55 and 74 . In the "closing the gender gap" scenario, the participation rates for women converge to those for men in each five-year age group by 2050.

Source: OECD projections based on data from the OECD Population and Labour Force Projections database.

StatLink 제내 http://dx.doi.org/10.1787/888933953867

\footnotetext{
${ }^{1}$ Randall S. Jones is head of the Japan/Korea Desk in the Economics Department of the OECD and Haruki Seitani is an economist on the Desk. The authors would like to thank OECD Economics Department colleagues Vincent Koen, Isabell Koske, Mathilde Pak and Alvaro Pereira, as well as Bert Brys and Dominque Paturot (OECD Centre for Tax Policy and Administration), Willem Adema, Hervé Boulhol, Chris Clarke, Yusuke Inoue and Tomoko Onoda (OECD Directorate for Employment, Labour and Social Affairs), Pierre Gouëdard (OECD Directorate for Education and Skills), and officials in the Japanese government, for valuable comments and/or discussions. Special thanks go to Jonathan Chaloff of the OECD Directorate for Employment, Labour and Social Affairs for his contributions on foreign workers and to OECD Economics Department colleagues Lutécia Daniel for technical assistance and Sisse Nielsen and Michelle Ortiz for technical preparation.
} 
Labour shortages are likely to intensify as Japan's population is projected to fall by onefifth to around 100 million by 2050 , while the share of elderly rises from $28 \%$ to $38 \%$. If labour market entry and exit by age and gender remain constant at 2017 levels, the labour force would contract by 4.5 million by 2030 and by 16.1 million (24\%) by 2050 (Figure 1). Increased social spending for the elderly and slower economic growth will put further upward pressure on gross government debt, which in 2018 reached 226\% of GDP, the highest ever in the OECD (2019 OECD Economic Survey of Japan). Sustaining employment and economic growth is essential to help Japan achieve fiscal sustainability and fulfil its promises to provide health and long-term care and pensions for the growing number of elderly.

Removing obstacles to employment would help Japan meet its fiscal challenges. It would also improve well-being by expanding opportunities, particularly for older persons and women. Indeed, a 2012 government survey found that 75\% of workers who reach the mandatory retirement age of 60 want to continue working (Takayama, 2013). Longer working lives would also enhance well-being by increasing labour and pension income for the elderly, thereby reducing their high relative poverty rate of $20 \%$. If labour market exit rates were reduced by $10 \%$ for each five-year age cohort between 55 and 74 (the "delayed retirement scenario" in Figure 1), the labour force in 2050 would be $7 \%$ larger than if labour market entry and exit rates were constant. Moreover, real output per capita would be $8.4 \%$ higher in 2050.

Removing disincentives to employment of women would also help to mitigate the impact of demographic changes. If the participation rates of women for each five-year age group were to converge to those of men by 2050 , the labour force would be $5 \%$ larger and real output per capita would be $6.8 \%$ higher. Combining the delayed retirement scenario with the convergence of participation rates of men and women, the labour force would be $13 \%$ larger than in the baseline scenario.

Fundamental labour market reform is thus a top priority. Japan's traditional model simultaneous recruitment of new graduates, lifetime employment, a seniority-based wage and promotion system, mandatory retirement and company-based training - was effective when Japan had a young and growing population. However, it is poorly suited to the era of 100-year lives, as it discourages the employment of older persons and women and labour mobility. A shift to more flexible employment and wage systems based on performance rather than age would enable Japan to better utilise its human capital. In addition, such an approach would help break down labour market dualism, which results in large wage and income gaps between regular workers and non-regular workers, who are predominantly women and older persons. In sum, fundamental labour reform is necessary to improve wellbeing by expanding opportunities and improving job quality by overcoming the negative aspects of the traditional model, such as long working hours.

As discussed in the 2017 OECD Economic Survey of Japan, boosting labour productivity is also a priority to ensure fiscal sustainability in the face of a shrinking labour force and sustain living standards. Labour productivity in Japan is a quarter below the top half of OECD countries, suggesting considerable scope to increase it. Moreover, Japan faces large productivity gaps between manufacturing and services and between large firms and SMEs. New technologies, such as digitalisation and robotics, could play a key role in narrowing such gaps and offsetting the fall in the labour force, though technological progress requires lifelong learning to ensure that workers have the necessary skills.

This chapter begins by analysing obstacles to employment of older workers and women and policies to overcome them. The third section discusses recent measures to increase the 
number of foreign workers in Japan. The fourth section focuses on the issue of labour market dualism, which has implications for employment and social inclusion. Policy recommendations are presented at the end of the chapter.

\section{Extending working lives}

In 2015, Prime Minister Abe appointed a Minister for Promoting Dynamic Engagement of All Citizens and then created the Council for Designing 100-Year Life Society in 2017. He stated that the focus should be on "improving each individual's abilities and responding to people's desire to learn and work" (Cabinet Secretariat, 2017).

\section{A reversal of falling employment rates for older persons since 2000}

The employment rate of men and women in their 60s has risen since the turn of the century, reversing the long-term decline that began in 1970 (Figure 2). The fall reflected the increasing generosity of public pensions and the shrinking number of self-employed workers (Usui et al., 2016). The upward trend in elderly employment rates since 2000 occurred in almost all OECD countries, and in many cases, was stronger than in Japan. The rise in Japan was driven by a number of factors:

- Improved health and longer longevity: since 1970, life expectancy at age 60 has risen from 19 years to 29 for women and from 16 years to 24 years for men.

- Increased educational attainment: the number of male workers with university degrees, who accounted for only 7\% of the male labour force in the 55-64 age group in 1975, surpassed the number of men without university degrees in 1990 . Employment rates rise with education in advanced countries (Grigoli et al., 2018).

- The transition toward less physically demanding jobs (Oshio et al., 2018).

- Policy reforms have encouraged older persons to continue working: for example, in 1995 , the government introduced a subsidy equivalent to $15 \%$ of the wage to workers between ages 60 and 64. In addition, pension reform has also played an important role (see below).

Figure 2. The employment rate of older persons in Japan has been trending up

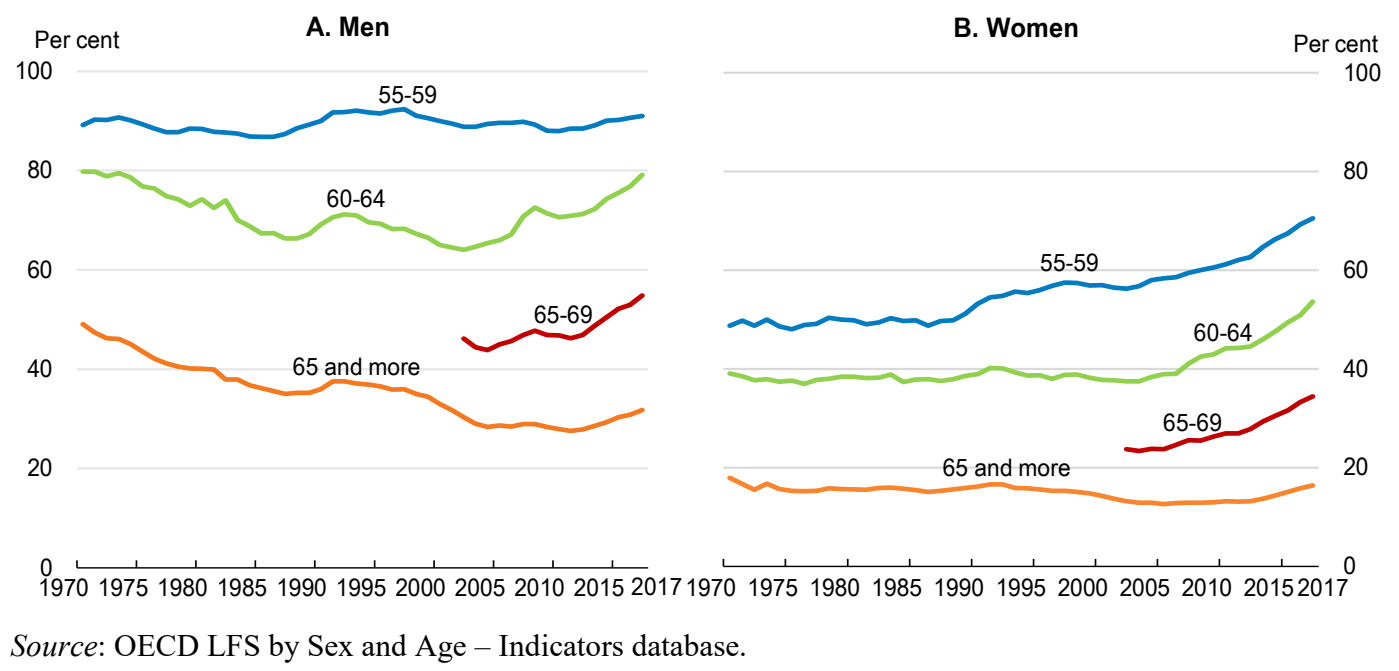

StatLink त्ञाजी http://dx.doi.org/10.1787/888933953886 
The employment rate for Japanese men is the highest in the OECD for the 55-59 age group and fifth highest for those in their early 60s (Figure 3). Japanese women's employment rates are above the OECD average for each age cohort between the ages of 55 and 69 (Panel B). However, for the elderly population (over 65), Japan's employment rates of $32 \%$ for men and $16 \%$ for women are closer to the OECD average, and far below leading countries, suggesting scope for increases.

The challenge is to further boost the employment rate of those aged 55 and up to mitigate the decline in the labour force (Figure 1). Changing the incentives to work for those aged 60 to 64, an age group that is typically in the transition from work to retirement, is a priority, in part, as it would also boost employment rates for subsequent age cohorts. The following sections discuss traditional Japanese labour market practices, the impact of recent reforms to lengthen working lives and the skills of older workers.

Figure 3. Older Japanese have relatively high employment rates

Persons in the labour force as a percentage of the population in each age group in 2017

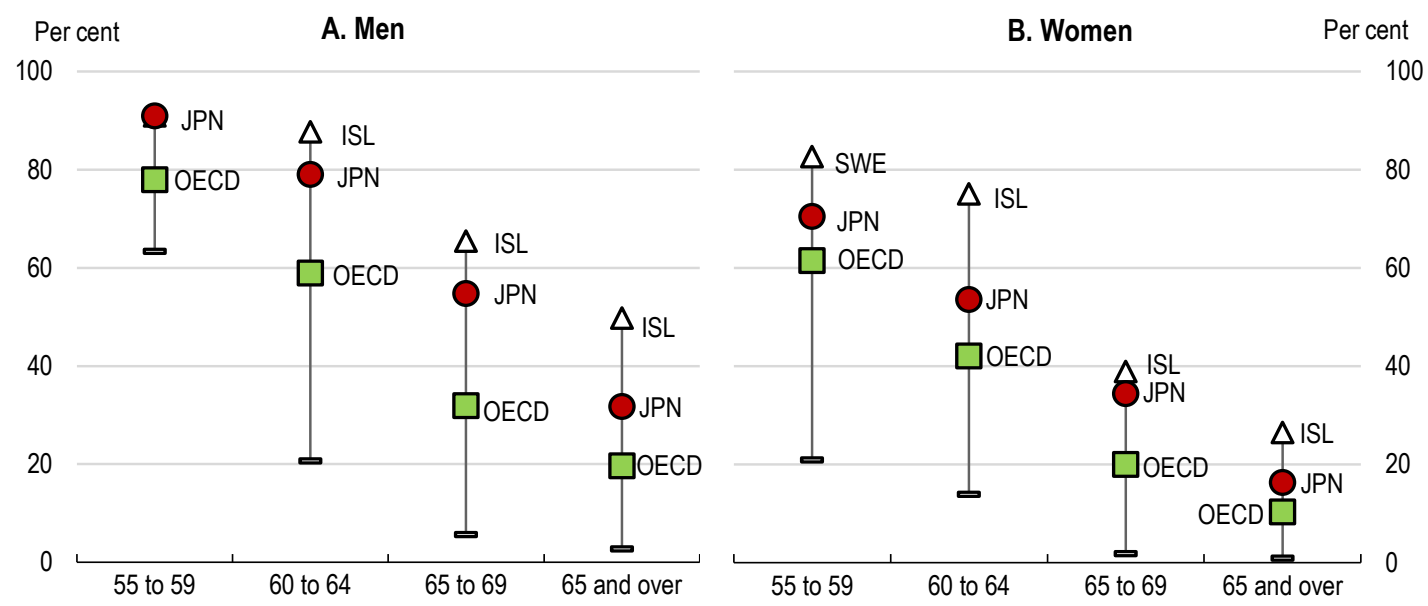

Note: The OECD is a weighted average.

Source: OECD LFS by Sex and Age - Indicators database.

StatLink त्ञाज http://dx.doi.org/10.1787/888933953905

\section{Japan's traditional labour market practices}

Japan's lifetime employment system is an implicit long-term employment contract for regular workers. Under this system, firms hire new graduates to work in a variety of positions, with the promise of a job until the mandatory retirement age. Seniority-based wages generate a lifetime commitment of workers to their firm by setting wages below marginal productivity for younger workers and offering wages greater than marginal productivity for those with long tenures. The long-term commitment encourages employers to develop company-specific skills by investing in their workers. This enhances firms' competitiveness and the productivity of workers, who are motivated to work hard for the survival of their firms. Firms use two mechanisms to raise wages: $i$ ) the base-up, which is set in annual labour-management negotiations; and ii) the seniority-based component determined by the company. In 2018, wages increased by $2.3 \%$, according to the government, with seniority-based pay accounting for about 1.8 percentage points. Wages rise quite steeply, particularly in large firms, until age 60 , the mandatory retirement age set by most firms (Figure 4). The seniority component of wages is large compared to other 
countries (Figure 5). As workers move from 10 to 20 years of tenure, wages are estimated to increase by $11 \%$, controlling for skills and other factors. This is the third highest in the OECD, behind Korea and Turkey.

Figure 4. The seniority-based wage system in Japan remains strong

Wage profile for male lifetime employees, 20-24 age group $=100$
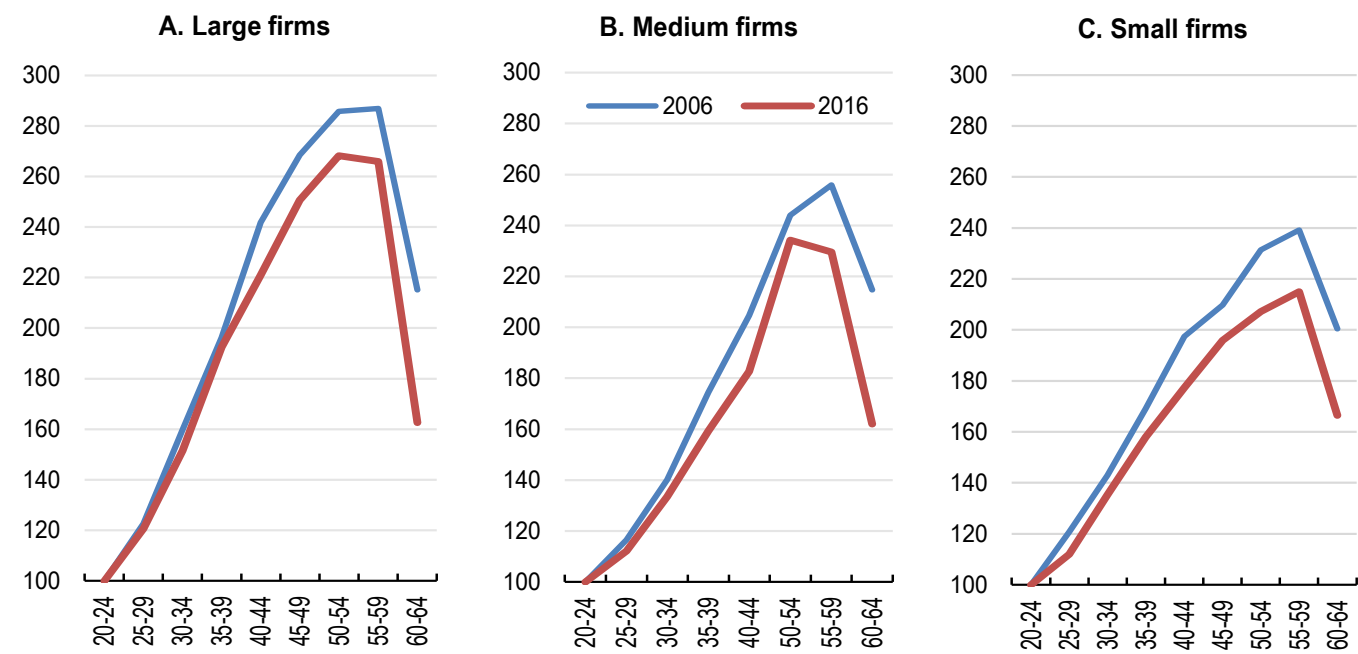

Note: Lifetime employees are all employees who were continuously employed by enterprises directly after leaving school or university. Large firms are those with more than 1000 employees and small firms are those with between 10 and 99.

Source: Japanese Ministry of Health, Labour and Welfare, Basic Survey on Wage Structure (2006, 2016).

StatLink 제에 http://dx.doi.org/10.1787/888933953924

Figure 5. The link between tenure and wages in Japan is one of the strongest in the OECD

Predicted wage growth (in percent) moving from 10 to 20 years of tenure, for persons aged 50-60, 2013

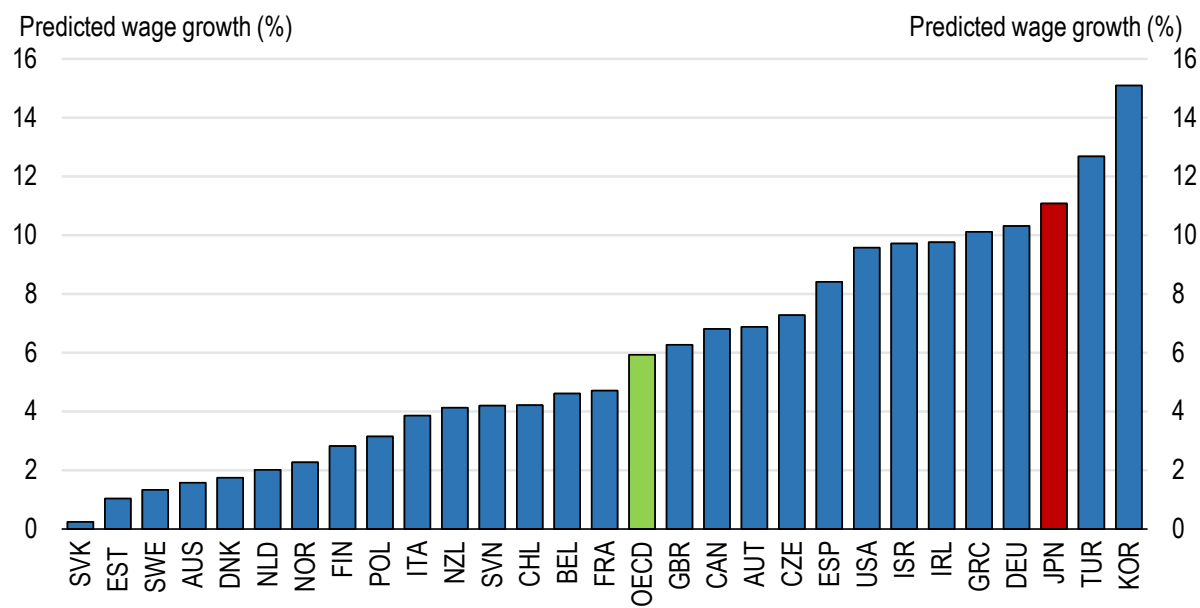

Note: Predicted wage growth estimates were obtained from a cross-sectional regression of tenure, squared tenure and controls for gender, experience, years of education, literacy and numeracy skills, occupation, skill use at work, and educational status of the parents. Source: OECD (2018f).

StatLink त्ताs http://dx.doi.org/10.1787/888933953943 
Mandatory retirement is an essential component of lifetime employment, given that employment protection makes it difficult for firms to dismiss regular workers. Firms do not wish to keep older workers once their rising seniority-based wage exceeds their productivity (Miyamoto, 2016). Firms rely on mandatory retirement to end implicit lifetime contracts.

Lifetime employment is not universal. In large firms, 38.9\% of employees in 2016 were lifetime employees, defined as those who have worked continuously for the same firm since finishing their education (Table 1). Lifetime employment is less prevalent in small firms and more so in manufacturing. Among workers in the 50-59 age group who were hired at graduation by large manufacturing firms, $46 \%$ had never changed employer, compared to $36 \%$ in non-manufacturing (OECD, 2018f). The share of female graduates who are lifetime employees is higher than for men until age 40 (Panel B), but it falls sharply beyond that age as many women exit the labour force to care for children or elderly relatives.

Table 1. Japan's lifetime employment system

\section{A. Lifetime employment is more prevalent in large firms}

Male lifetime employees as a percentage of all male employees by age and firm size in 2016

\begin{tabular}{ccccc}
\hline Age & Total & Large firms & Medium firms & Small firms \\
\hline $15-29$ & 46.7 & 52.4 & 49.9 & 32.4 \\
$30-39$ & 23.5 & 31.0 & 24.6 & 11.8 \\
$40-49$ & 24.3 & 36.8 & 23.3 & 8.9 \\
$50-59$ & 23.8 & 38.9 & 20.6 & 7.3 \\
\hline
\end{tabular}

B. Lifetime employment is more prevalent among graduates and among men after age 40

Lifetime employees as a percentage of all employees by age, gender and graduate status in 2016

\begin{tabular}{ccccc}
\hline Age & $\begin{array}{c}\text { Female junior or high } \\
\text { school graduates }\end{array}$ & $\begin{array}{c}\text { Female university } \\
\text { graduates }\end{array}$ & $\begin{array}{c}\text { Male junior or high } \\
\text { school graduates }\end{array}$ & $\begin{array}{c}\text { Male university } \\
\text { graduates }\end{array}$ \\
\hline All ages & 14.3 & 43.9 & 21.0 & 37.9 \\
$15-29$ & 32.1 & 69.2 & 37.8 & 58.2 \\
$30-39$ & 11.0 & 34.0 & 15.9 & 32.3 \\
$40-49$ & 10.1 & 22.2 & 18.5 & 33.1 \\
$50-59$ & 6.3 & 14.5 & 17.1 & 33.9 \\
\hline
\end{tabular}

Note: Lifetime employees are all employees who were continuously employed by enterprises directly after leaving school or university. Large firms are those with more than 1000 employees and small firms are those with between 10 and 99. The total in Panel A does not include persons over age 60. For university graduates in Panel B, the share is underestimated, as persons with masters degrees are included in the denominator (all university graduates) but not in the numerator (university graduates who are lifetime employees).

Source: Ministry of Health, Labour and Welfare, Basic Survey on Wage Structure, 2016.

Japan's labour market is also characterised by the simultaneous hiring of new graduates, which helps to avoid periods of joblessness and contributes to the relatively low youth unemployment rate. However, young people who are not university graduates have a low rate of lifetime employment (Table 1, Panel B). The simultaneous hiring of graduates also limits lifetime employment opportunities for those who graduate during economic downturns. The Japanese business federation, Keidanren, which comprises over 1300 companies, has announced that it will no longer set guidelines for simultaneous hiring.

Lifetime employment is fading in the face of slow growth and intensifying competitive pressures (Table 2). Among workers in their 30s and 40s in large firms, the share who have remained with the same employer since leaving education was 15.0 and 9.4 percentage 
points, respectively, lower in 2016 than it was in 2006. The decline in lifetime employment has contributed to some flattening of the seniority wage curve (Figure 4). In large firms, the ratio of wages for men aged 55 to 59 relative to the 20-24 age cohort edged down from 2.9 times in 2006 to 2.7 in 2016, as firms place greater importance on the specific jobs and roles of individual workers when setting wages. In addition, performance has become more important in setting bonuses (Ministry of Health, Labour and Welfare, 2017a). These developments tend to reduce discrepancies between wages and productivity.

The seniority-based wage system and mandatory retirement are among the most important barriers to the employment of older workers in Japan and their difficult transition to retirement. Seniority-based pay schemes have a negative impact on the employment of older workers in other countries as well. A cross-country comparison of the relationship between the age-wage premium and the retention rate of workers aged 60-64 shows a negative correlation in OECD countries (OECD, 2018f).

Table 2. Lifetime employment was less prevalent in 2016 than in 2006

Change in the share of male employees who are lifetime employees (in percentage points)

\begin{tabular}{crccr}
\hline Age & Total & Large firms & Medium-sized firms & Small firms \\
\hline $15-29$ & 3.5 & 1.1 & 2.9 & 2.1 \\
$30-39$ & -7.7 & -15.0 & -7.6 & -1.2 \\
$40-49$ & -5.1 & -9.4 & -4.3 & -1.5 \\
$50-59$ & 1.1 & -1.9 & -0.8 & 0.0 \\
\hline
\end{tabular}

Note: Lifetime employees are all employees who were continuously employed by enterprises directly after leaving education. Large firms are those with more than 1000 employees and small firms are those with between 10 and 99 .

Source: Ministry of Health, Labour and Welfare, Basic Survey on Wage Structure, 2006 and 2016.

\section{Policies that have helped to lengthen working lives}

Changes in the public pension system have contributed to the rising employment rate for older persons in Japan (Figure 2):

- The eligibility age for the flat-rate component of Employees' Pension Insurance (EPI), the public pension programme for private-sector employees, was hiked for men by one year every three years starting in 2001, reaching 65 in 2013 (Table 3). The increase in the employment rate for the 60-64 age group coincided with this reform (Figure 6). As for women, the hike in the eligibility age for the wageproportional benefit in the EPI (from 55 to 60) over 1987-99 and the flat-rate benefit (from 60 to 65) over 2006-18 are associated with the rise in the employment rate for those aged 55 to 59 (Panel B). However, the increase in the pension eligibility age has not kept pace with the rise in life expectancy at age 65 .

- Pension benefits have become less generous since 1985 , as shown by the declining replacement rate.

- The earnings test continues to limit the labour supply of older workers by reducing pension payments for those who continue to work. However, the easing of this disincentive is estimated to have increased the labour force by $0.7 \%$ to $1.9 \%$ per year for men over $1995-2007$ and by $0.65 \%$ to $0.9 \%$ for women (Oshio et al., 2011). 
Figure 6. The rise in the employment rate is linked to hikes in the pension eligibility age

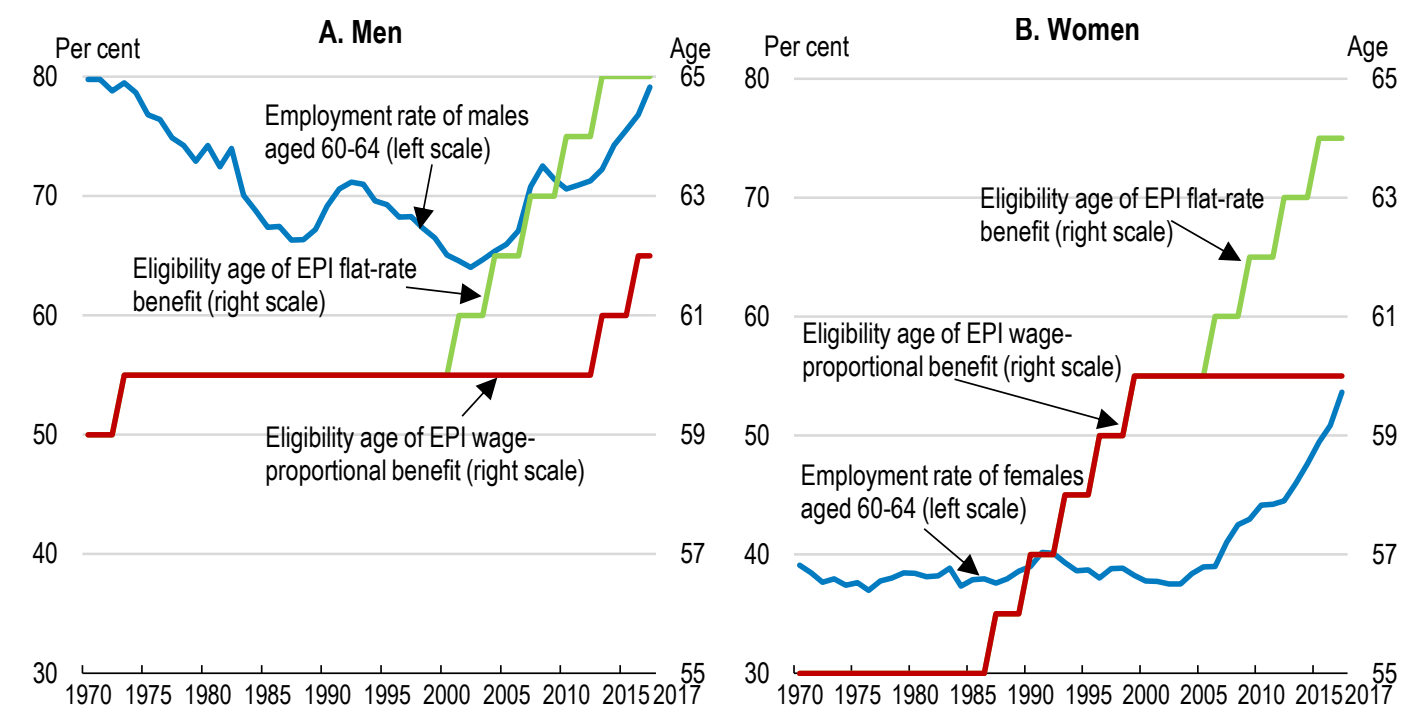

Source: OECD LFS by Sex and Age - Indicators database.

StatLink त्ञाजा http://dx.doi.org/10.1787/888933953962

The growing gap between the mandatory retirement age set by firms, typically at 60 , and the pensionable age (rising to 65) created a serious social concern. The Act for the Stabilisation of Employment of Elderly Persons was revised to require employers who have set a retirement age below 65 to introduce one of three measures from 2006: $i$ ) raise the mandatory retirement age to at least 65 , which would allow employees to continue as regular workers; ii) abolish mandatory retirement; or iii) retain or re-hire older workers who wish to continue working until age 65 . The third option, the so-called "continuous employment system", does not require firms to maintain wages or working hours past age 60 . In some cases, firms and workers cannot reach agreement on working conditions after age 60 .

Few companies have opted to raise their mandatory retirement age or eliminate it, reflecting the high wage costs due to steep seniority-based wage increases and the high employment protection for regular workers. Instead, a large majority of firms of all sizes have opted for the third option of keeping the mandatory retirement age at 60 and re-hiring workers at lower wages. Indeed, the share of firms setting mandatory retirement at age 60 declined only modestly from $91 \%$ in 2005 to $81 \%$ in 2016 (Figure 7). Not surprisingly, firms that include a large seniority pay component in their wage systems are more likely to choose to re-hire workers at age 60 (OECD, 2018f).

The employment rate of the 60-64 age group has risen as they face the higher pension eligibility age and the opportunity for continuous employment. The increase is particularly large in the case of those employed at large firms where mandatory retirement is more strictly enforced (Kondo and Shigeoka, 2016). However, only about one-fifth of firms extend regular employment for workers reaching age 60 . The remainder re-hire them as non-regular workers, a category that includes fixed-term, part-time and dispatched workers. As a result, the share of employees who were non-regular employees in 2017 jumps from only $11 \%$ for men aged $55-59$ to $45 \%$ for men in their early 60 s and to $57 \%$ for those in their late 60s (Figure 8). For women, the share of non-regular workers at age 55-59 is much higher at $58 \%$, and rises to $72 \%$ for those in their early 60 s. 
Table 3. Measures affecting the employment of older persons

\begin{tabular}{|c|c|c|}
\hline Year & Measures related to mandatory retirement & Pension reform \\
\hline 1986 & $\begin{array}{l}\text { Firms obliged to make an effort to not set mandatory } \\
\text { retirement below the age of } 60 \text {. }\end{array}$ & \\
\hline 1987 & & $\begin{array}{l}\text { The eligibility age for women for the wage-proportional } \\
\text { benefit in the EPI begins rising from age } 55 \text { to } 60 \text {. }\end{array}$ \\
\hline 1990 & $\begin{array}{l}\text { Firms obliged to make an effort to continue employment } \\
\text { after the mandatory retirement age. }\end{array}$ & \\
\hline 1994 & $\begin{array}{l}\text { The government announces that firms will be prohibited from } \\
\text { setting mandatory retirement below age } 60 \text {. }\end{array}$ & $\begin{array}{l}\text { Announcement that the eligibility age for men for the flat-rate } \\
\text { benefit in the EPI will be raised gradually from } 60 \text { to } 65 \text { over } \\
2001-13 \text {. }\end{array}$ \\
\hline 1998 & $\begin{array}{l}\text { Mandatory retirement below age } 60 \text { is prohibited. Firms are } \\
\text { obliged to make an effort to continue employment to age } 65 \text {. }\end{array}$ & \\
\hline 1999 & & $\begin{array}{l}\text { The eligibility age for women for the wage-proportional } \\
\text { benefit in the EPI reaches } 60 \text {. }\end{array}$ \\
\hline 2001 & & $\begin{array}{l}\text { The eligibility age for men for the flat-rate benefit in the EPI } \\
\text { begins increasing from } 60 \text {. }\end{array}$ \\
\hline 2004 & $\begin{array}{l}\text { The government announces that firms will be required to } \\
\text { offer continued employment until age } 65 \text { beginning in } 2006 \text {. }\end{array}$ & The income test to receive the EPI is relaxed. \\
\hline 2006 & $\begin{array}{l}\text { Firms are required to continue employment until the pension } \\
\text { eligibility age subject to screening based on ability or service } \\
\text { record. }\end{array}$ & $\begin{array}{l}\text { The eligibility age for women for the flat-rate benefit in the } \\
\text { EPI begins to rise from } 60 \text { to } 65 \text {. }\end{array}$ \\
\hline 2012 & $\begin{array}{l}\text { The government announces that firms will be required to } \\
\text { offer continued employment until age } 65 \text { for everyone who } \\
\text { wants to remain in the firm (i.e. no screening) from } 2013 \text {. }\end{array}$ & \\
\hline 2013 & & $\begin{array}{l}\text { The eligibility age for men for the flat-rate benefit in the EPI } \\
\text { reaches } 65 \text {. Their eligibility age for the wage-proportional } \\
\text { benefit in the EPI begins rising from } 60 \text { to } 65 \text { by } 2025 \text {. }\end{array}$ \\
\hline 2018 & & $\begin{array}{l}\text { The eligibility age for women for the flat-rate EPI benefit } \\
\text { reaches } 65 \text {. Their eligibility age for the wage-proportional } \\
\text { benefit in the EPI begins rising from } 60 \text { to } 65 \text { by } 2030 \text {. }\end{array}$ \\
\hline
\end{tabular}

Note: Japan's public pension system includes the National Pension, which is mandatory in principle for the self-employed, students, part-timers who are not eligible to join the EPI and full-time homemakers whose spouses are not covered by the EPI. The EPI includes a flat-rate portion, which equals the full benefit under the National Pension, and an income-related portion.

Source: OECD Secretariat.

Given that non-regular workers are paid around $40 \%$ less per hour on average than regular workers, the increase in non-regular employment in the 60-64 age group lowers wages. A government firm-level survey of workers in their 60 s found that nearly one-third of re-hired workers experienced a wage cut of more than $40 \%$, while only $10 \%$ earn the same as previously (JILPT, 2016). Men in the 60-64 age cohort in 2016 faced wage declines ranging from $39 \%$ in large firms to $23 \%$ in small firms, compared to the wages of the 55-59 age cohort (Figure 4). The decline is much larger than those faced by workers in 2006, before the implementation of the continuous employment system, which leads to the shift to nonregular employment. Lower wages, to some extent, are consistent with changes in job responsibilities. With the move to non-regular status at age 60, a government survey found that many workers are transferred to jobs with fewer responsibilities (JILPT, 2016), implying less use of their skills than in their former jobs. Following the National Personnel Authority's recommendation in 2018 that government officials be allowed to work past age 60 by cutting their wages by $30 \%$, the government is considering gradually raising their retirement age towards 65 . 
Figure 7. Most firms have kept their mandatory retirement age at 60

Trends in mandatory retirement age adopted by companies

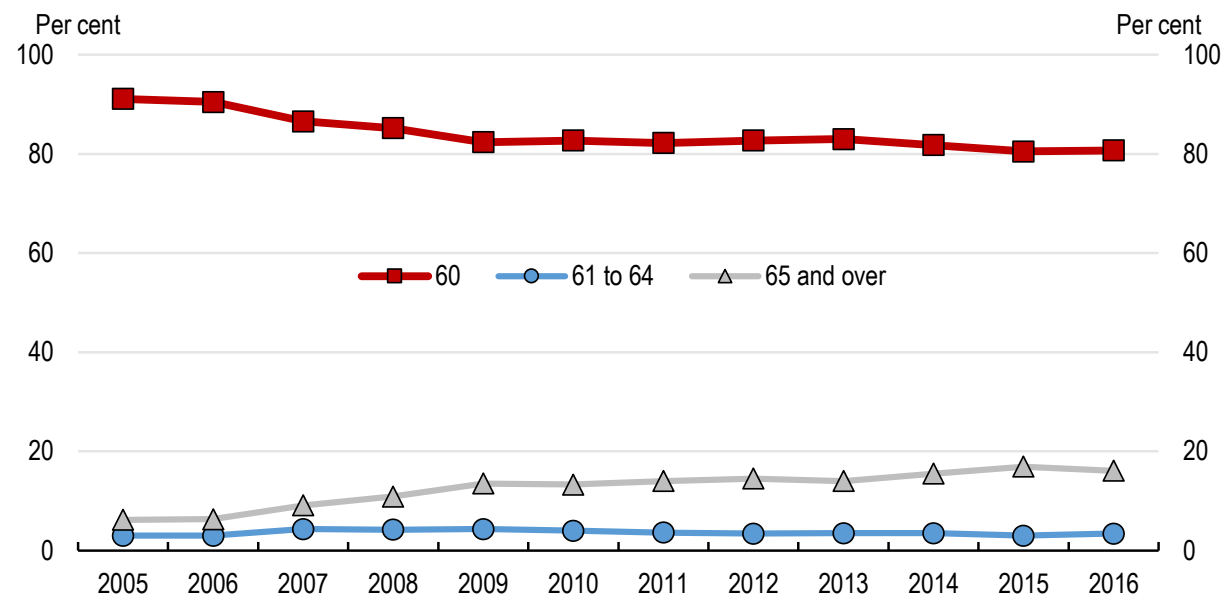

Source: Ministry of Health, Labour and Welfare, General Survey on Working Conditions, 2017.

StatLink 제매 http://dx.doi.org/10.1787/888933953981

While a lower wage may be justified by declining productivity of older workers and the shift to jobs with fewer tasks, older workers complain about the size of wage cuts. In a government survey, $30 \%$ of re-hired older workers said that the wage cut was not justified "because their job duties have hardly changed" or because their "contribution to the company is not less than previously" (21\%). Another $17 \%$ reported that "although the weight of work responsibility has changed slightly, the wage was reduced too much" (JILPT, 2015).

Figure 8. Many workers become non-regular employees after reaching the age of 60

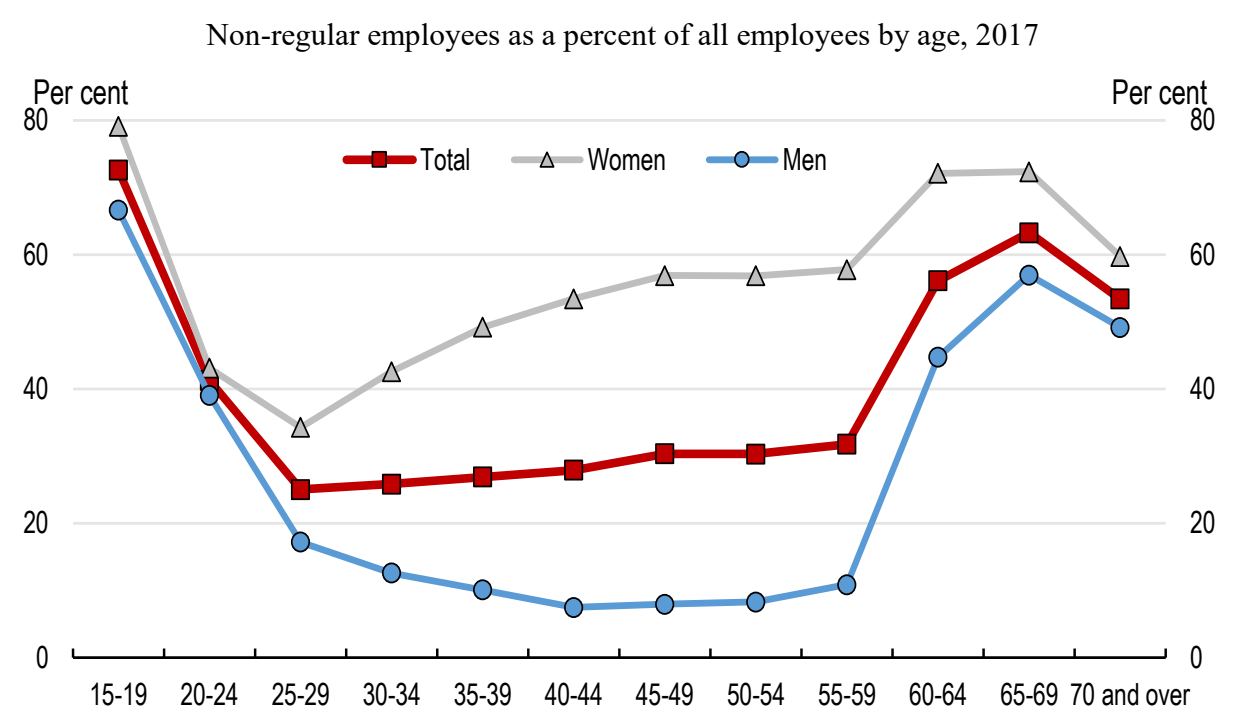

Source: Ministry of Internal Affairs and Communications. Labour Force Survey (Basic Tabulation), 2017.

StatLink 제매 http://dx.doi.org/10.1787/888933954000 
In sum, the reforms to lengthen working lives have benefited firms by allowing them to rehire regular workers in low-paid non-regular positions, thereby avoiding the costs imposed by the seniority wage system and high employment protection. However, the change in workers' status, responsibilities and wages when they are re-hired in non-regular jobs has negative consequences for their well-being. According to a 2018 government survey, about $16 \%$ of workers who reach age 60 do not continue employment, resulting in a significant fall in employment rates between the 55-59 and 60-64 age groups (Figure 3). Demoting older workers, regardless of individual capacities, tends to lower their productivity, as many do not fully utilise the job-specific skills they acquired prior to mandatory retirement. Moreover, they may be less motivated because of lower job satisfaction and pay. It is essential to increase wage flexibility over workers' lifetime and avoid sizeable wage cuts at age 60 that undermine workers' well-being and motivation to work and reduce productivity.

\section{The skills of older workers}

Japan has a high level of human capital. Japanese 15-year-olds are consistently among the top performers in the OECD's Programme for International Student Assessment (PISA). The share of its adult population with a tertiary education is well above the OECD average. Japanese adults have the highest proficiency in literacy and numeracy in the Survey for Adult Skills, according to the OECD Programme for the International Assessment of Adult Competencies (PIAAC). However, the use of numeracy, ICT and problem-solving skills at work by older persons (55 to 65) is below the OECD average (Figure 9). Moreover, the gap in skill use between older workers and younger workers (25-34) is large compared to the OECD average, especially in problem solving. In addition, the use of supervising, planning and influencing skills drops off sharply after age 60, which also reflects the shift of workers to less demanding, non-regular jobs once they reach the mandatory retirement age. Less use of skills by older workers may also be linked to their lower skill levels in Japan (Figure 10). The gap in skill levels between prime-age and older workers suggests that workers would benefit from increased investment in life-long learning.

\section{Reforms to extend the careers of older persons}

The structural factors noted above - improved health and longer longevity, higher educational attainment and the changing nature of work - will continue to boost the employment of older persons. A recent OECD study estimated that the labour force participation rate of the 55-74 age group in Japan will rise by 6 percentage points by 2030, led by increased education and life expectancy (Guillemette et al., 2019). Structural factors should be reinforced by a number of reforms. First, the right of firms to set a mandatory retirement age should be abolished, as stressed in past OECD Economic Surveys of Japan (OECD, 2011; OECD, 2013a; OECD, 2015c; OECD, 2017b). Second, the pension eligibility age should be further increased beyond the current target of 65 by 2030. Third, wage-setting systems should give less weight to seniority and more to job and performance. Fourth, expanding lifelong training and education is necessary to equip older persons with the skills for an increasingly digital economy to extend their employability. Fifth, ensuring adequate job search support would help workers remain active. Sixth, promoting appropriate working conditions is important to encourage longer working lives. 
Figure 9. Older workers' use of skills at work in Japan is relatively low

Index, ranging from 1 (not used) to 5 (used daily), for the 55-65 age group

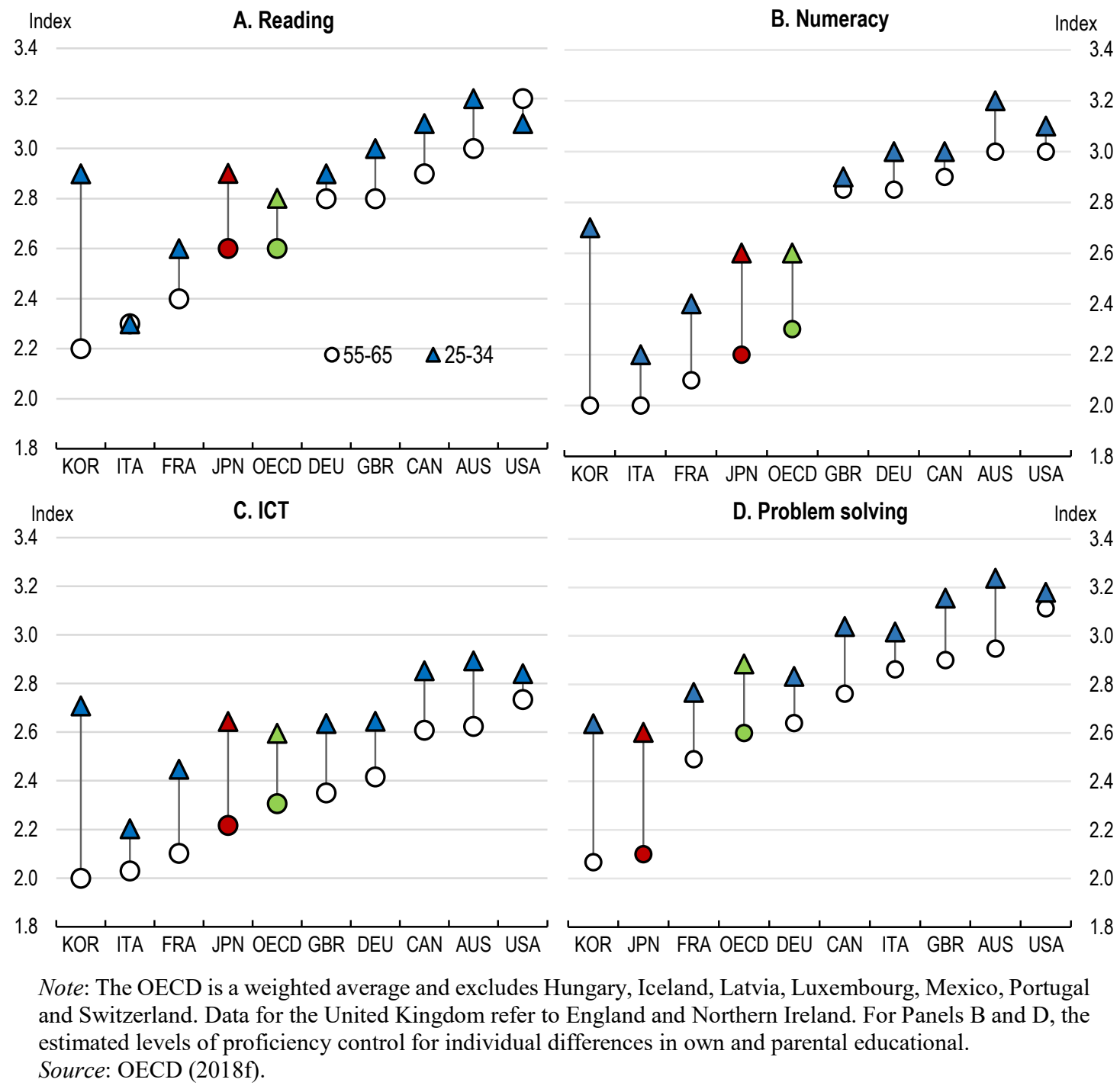

StatLink 제므 http://dx.doi.org/10.1787/888933954019

\section{Abolishing mandatory retirement}

Mandatory retirement and the seniority-based wage system, combined with high employment protection, reduce the quantity and quality of employment opportunities for older persons. Indeed, firms' efforts to downsize their staff are concentrated on older workers. Japan is unique in setting a mandatory retirement age (60 in $81 \%$ of firms) below the pension eligibility age ( 65 for the flat-rate portion of the EPI). The best solution is to abolish mandatory retirement, as in many other OECD countries, to allow workers the right to choose when they leave the labour force. Giving people better choices and incentives to continue working at an older age is crucial for responding to the challenge of rapid population ageing. The OECD Recommendation of the Council on Ageing and Employment Policies stated that countries should "discourage or further restrict mandatory retirement by employers" (2018e). 
Figure 10. Skills of older workers in Japan are well below those of younger workers

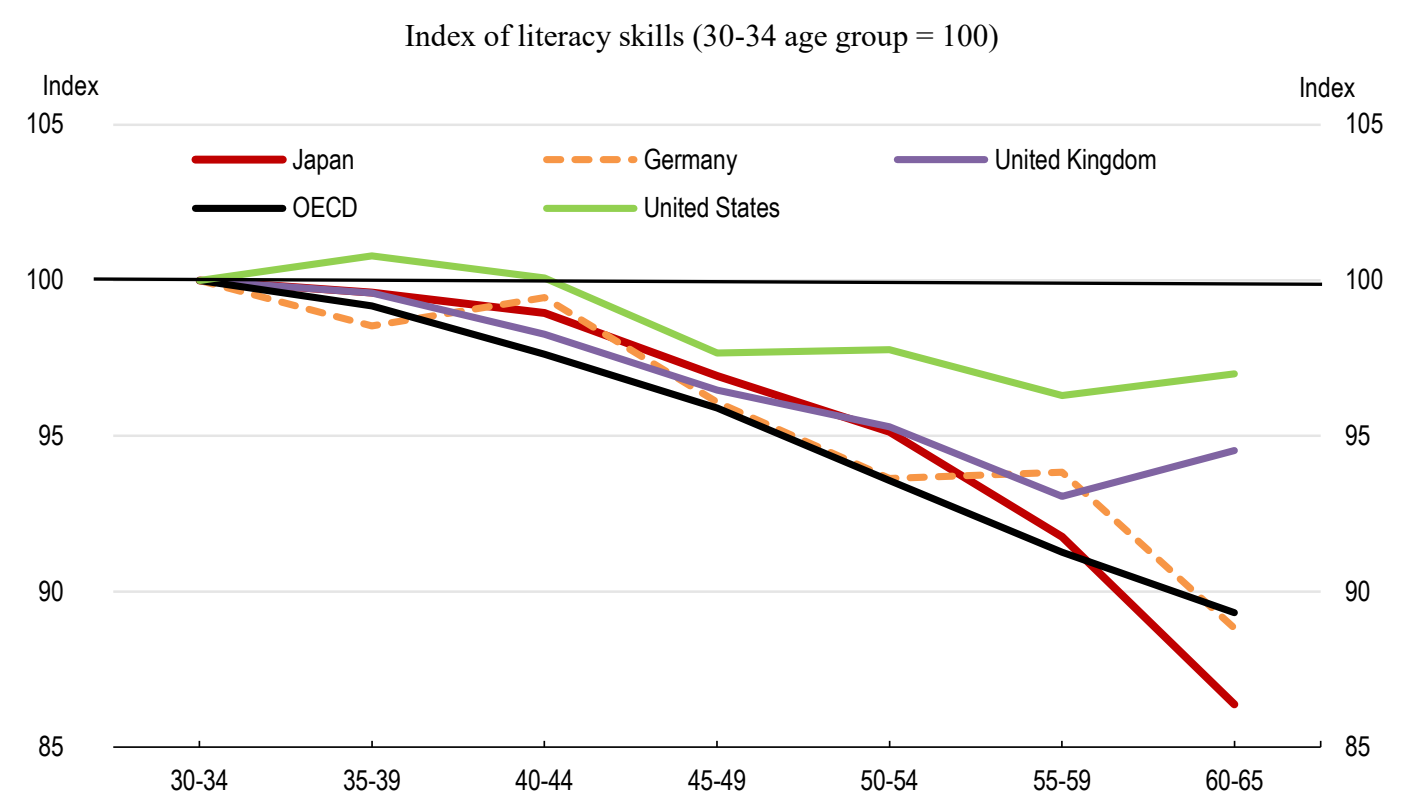

Note: The OECD is a weighted average and excludes Hungary, Iceland, Latvia, Luxembourg, Mexico, Portugal and Switzerland. Estimates were obtained by regressing factor variables indicating age, gender, and country on literacy proficiency.

Source: OECD (2018f).

StatLink : त्ञाज http://dx.doi.org/10.1787/888933954038

Allowing workers to continue their main careers beyond age 60 would avoid the demotion to non-regular jobs that do not fully utilise their skills. A study of workers aged 60 and older shows that fully using their skills increases the probability of job satisfaction by $28 \%$ (OECD, 2018f). Letting older persons remain in their career jobs past age 60 would increase the share that choose to work. Moreover, the productivity of older workers would be higher if they remain in their career jobs, in part by increasing incentives for firms to invest more in their training. Higher labour force participation, productivity and wages for older workers would also boost their incomes and eventually their pensions, reducing poverty among the elderly.

Reducing age discrimination would help expand employment opportunities for older persons. Unlike many other OECD countries, Japan does not have general age discrimination legislation. However, a 2007 law forbids age discrimination during recruitment and employment, which in principle prevents employers from setting age limits in job offers. This principle should be extended to prevent age from being a criterion to force a worker to leave a firm. It should be accompanied by reductions in employment protection for regular workers so that firms do not focus reductions in staffing on older workers (see below).

\section{Raising the pension eligibility age and reforming the pension system}

Abolishing mandatory retirement and removing other obstacles to the employment of older persons would facilitate further hikes in the pension eligibility age. Even after reaching age 65 by 2025 for men and 2030 for women (Table 3), the eligibility age will remain low relative to the average healthy life span, which is currently 72.1 years for men and 74.8 
years for women. A recent OECD study found that raising the standard retirement age by one year increased the participation rate of the 55-74 age group by 0.8 percentage points (Guillemette et al., 2019). By 2016, 12 OECD countries had raised their pension eligibility age above 65 and 18 countries have legislated reforms to raise the age (OECD, 2017c). This is in line with the OECD Recommendation of the Council on Ageing and Employment Policies, which stated that countries should "ensure that the old-age pension system encourages and rewards later retirement in line with increased life expectancy" (OECD, 2018e).

Raising the eligibility age is also essential to ensure adequate retirement income. The relative poverty rate of the elderly in Japan is $20 \%$, well above the $12.5 \%$ OECD average. Relying on social welfare, notably the Basic Livelihood Protection Programme, to limit elderly poverty would be costly and would undermine incentives to contribute to the public pension system. Under its current parameters, the future gross replacement rate of public pensions in Japan is one of the lowest in the OECD at 35\% for one-person households (Figure 11). By law, the replacement rate must remain above 50\% for couple households (by the Japanese calculation method) in the actuarial valuations conducted every five years. With the pension contribution rate reaching $18.3 \%$ in FY 2017, the best way to raise the replacement rate is to increase the pension eligibility age. The government's 2014 actuarial valuation suggests that delaying the start of pension benefits to 68 would increase the replacement rate by more than 10 percentage points in all scenarios by 2050 (Table 4). If it were delayed further to age 70, it would have an even stronger impact on the replacement rate. In addition to promoting the employment of older persons and reducing elderly poverty, a hike in the pension eligibility age would also lift output growth and improve intergenerational equity. Indeed, a person born in 1940 receives $16.4 \%$ of lifetime earnings in net transfers, while one born in 2010 pays $12.0 \%$ (OECD, 2017b).

Figure 11. The projected replacement rate of Japan's public pension system is low

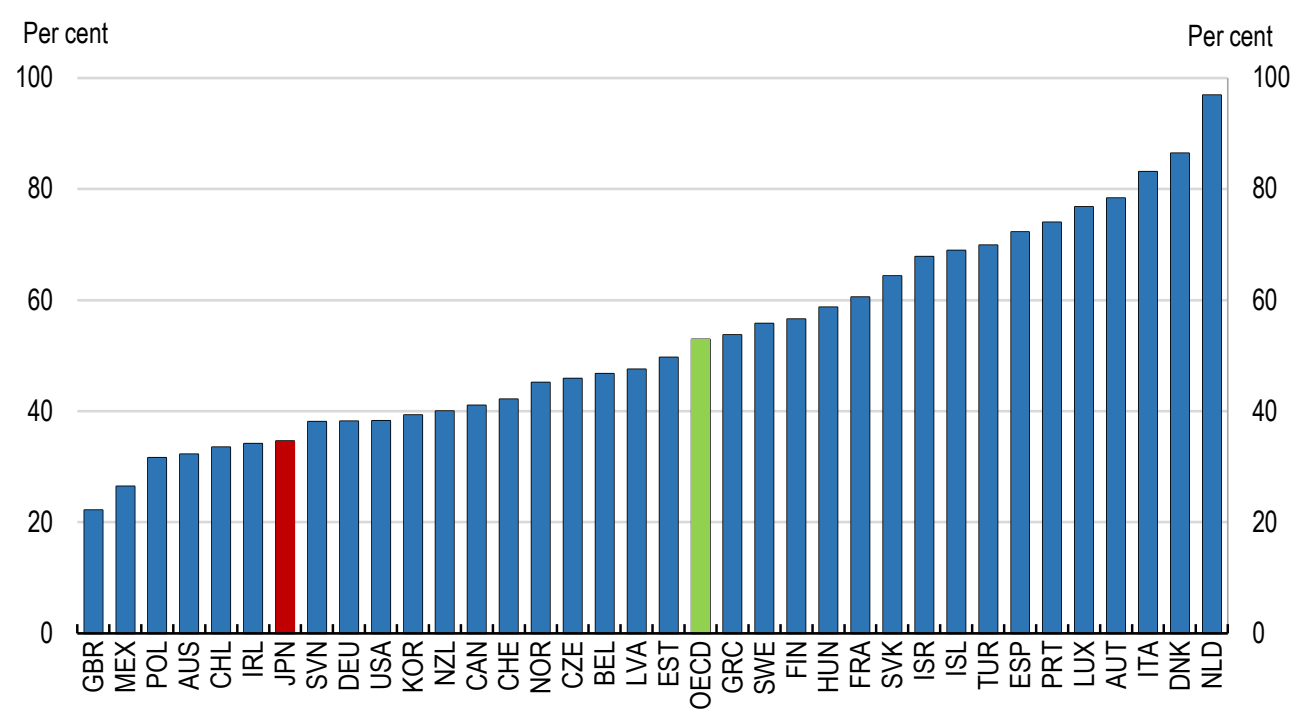

Note: Future gross replacement rates for full-career average-wage workers under current legislation. The replacement rate is the pension payment as a percentage of a pre-retirement income. Source: OECD (2017c). 
Table 4. Raising the pensionable age leads to a large increase in the replacement rate

Per cent

\begin{tabular}{|c|c|c|c|c|c|c|c|c|}
\hline \multirow{2}{*}{ Cases $^{1}$} & \multicolumn{2}{|c|}{ Real GDP growth rate } & \multicolumn{3}{|c|}{$\begin{array}{l}\text { Replacement rate }{ }^{2}(\%) \text { in } 2050 \\
\text { for pension eligibility age of: }\end{array}$} & \multicolumn{3}{|c|}{$\begin{array}{l}\text { Replacement rate }^{2}(\%) \text { in } 2050 \\
\text { for retirement age of: }\end{array}$} \\
\hline & FY 2014-23 & $\begin{array}{l}\text { FY } 2024 \\
\text { onward }\end{array}$ & 65 years & 68 years & 70 years & 65 years & 68 years & 70 years \\
\hline Case C & 1.1 & 0.9 & 51.0 & 63.9 & 72.5 & 57.6 & 74.4 & 86.2 \\
\hline Case $\mathrm{E}$ & 1.1 & 0.4 & 50.6 & 63.3 & 71.8 & 57.1 & 73.8 & 85.4 \\
\hline Case $\mathrm{G}^{3}$ & 0.2 & -0.2 & 42.0 & 52.8 & 60.0 & 48.4 & 62.6 & 72.6 \\
\hline Case $\mathrm{H}^{4}$ & 0.2 & -0.4 & 41.9 & 52.7 & 59.8 & 47.9 & 61.9 & 71.7 \\
\hline
\end{tabular}

1. The table shows four of the eight simulations done by the Ministry of Health, Labour and Welfare (2014). Total pension benefit payments are fixed, resulting in variations in the replacement rate. The simulations assume that the earnings test to receive pension benefits is abolished.

2. Pension benefit, including the impact of macroeconomic indexation, as a percentage of final earnings. The replacement rate was $62.7 \%$ in FY 2014.

3 . For the retirement age of 65 , the replacement rate is for 2058 .

4. For the retirement age of 65, the replacement rate is for 2054.

Source: Ministry of Health, Labour and Welfare (2014); and OECD calculations.

The government has proposed allowing older persons to delay the start of pension benefits, which can begin as early as age 60 , until after age 70 , while raising the continuous employment age to 70 . The pension amount is adjusted depending on the age that payments begin. A delayed pension at age 70 is $142 \%$ of that at age 65 , in principle, and an early pension at age 60 is $70 \%$, which in both cases are not far from actuarial neutrality. Once pension benefits begin, the receivable rate is permanently fixed. The impact of allowing workers to delay the start of pension benefits beyond 70 is likely to be modest, as only $1 \%$ of pension recipients currently choose to start receiving pensions after age 65 . Delaying the receipt of pension benefits would be more attractive if the earnings test were not used to calculate benefits. In the Basic Policy on Economic and Fiscal Management and Reform 2018, the government stated that it would consider amending the earnings test.

The coverage of EPI for non-regular workers should be expanded in order to reduce old age poverty, especially for women. In 2016, EPI coverage was expanded to include parttime workers in firms with more than 500 employees, working at least 20 hours per week and receiving a monthly wage of at least JPY 88000 (USD 783). The same rule has applied since 2017 to workers in firms with 500 employees or less if there is an agreement between labour and management. Coverage should be further expanded to non-regular workers with fewer working hours and lower earnings.

\section{Flattening the seniority wage curve}

An end to mandatory retirement, or even an increase in the retirement age, would force firms to reduce the link between wages and seniority to limit the financial impact from employing more older workers (Seike, 2015). An empirical study found that the rise in the retirement age from 55 to 60 in the mid-1980s in Japan significantly flattened the wage curve (Clark and Ogawa, 1992). As noted above, mandatory retirement allows firms to limit wage costs, given the link between wages and seniority, combined with high employment protection that makes it difficult to dismiss regular workers. The OECD Recommendation of the Council on Ageing and Employment Policies called on employers and worker representatives to "review their practices in setting pay to reflect productivity and competences, not age" (OECD, 2018e). Japanese firms, particularly large ones, are beginning to give greater importance to workers' job duties and performance and less to 
seniority in determining wages. Although the move away from seniority creates uncertainty among workers about their lifetime earnings, they would benefit from being able to work longer. As noted above, a government survey found that around three-quarters of older persons who have reached the mandatory retirement age want to continue working.

A better alignment between the costs of employing older workers and their productivity is necessary to boost the employment of older persons. The introduction of the principle of "equal pay for equal work" in the work style reform bill that was passed in 2018 is a step in this regard. Applying this principle would directly link wages and workers' productivity (Miyamoto, 2016), although this is difficult in practice (see below). Moreover, it would encourage mid-career hiring (so-called "secondary hiring"), as workers who change firms would not face the loss in wages typical under a seniority-based system. However, the practice of demoting workers at age 60 to less demanding positions, as noted above, would limit the benefit of the equal pay for equal work principle. Making equal pay for equal work beneficial for older workers thus requires eliminating mandatory retirement.

Ultimately, wages are decided by employers and employees, making it difficult for the government to push firms away from seniority-based wages. However, the government could provide an example in public-sector wage-setting arrangements by introducing performance pay and limiting automatic rises in salary with tenure. This will be particularly important when it designs the system to raise the retirement age of government officials toward 65. It could also promote mid-career hiring, which creates competition among employers for workers. Under seniority-based wages, young workers accept lower pay in exchange for a promise of higher pay in the future. With more competition across firms, workers may thereby be able to negotiate higher wages at younger ages, thereby weakening the role of tenure in pay scales, which may support young families. Another issue related to mid-career mobility is the retirement allowance, which is based on an agreement between employers and workers. The retirement allowance is a deferred payment of wages that rewards long-time employees, thereby encouraging long tenure. In addition, tax deductions on the retirement allowance rise sharply after 20 years of tenure, discouraging workers from changing firms before reaching that point. To facilitate mid-career labour mobility, the government should smooth the tax deduction.

\section{Maintaining and improving skills requires life-long learning in the digital age}

The tradition of a three-stage life - education, followed by a career, and then retirement is no longer appropriate in the context of 100 -year life spans and accelerating technological change. The skills mastered by young people in their teens or early 20 s cannot last an entire career that will extend into their 70 s or even 80 s, especially in the context of a rapidly changing job market (Gratton and Scott, 2017). A skills shortage is already evident in Japan, as employers struggle to find workers with the necessary skills to fill vacancies, with more than 1.6 job openings per applicant since May 2018. Moreover, skills erode with age.

Lifelong learning is essential to achieve the government's Society 5.0 agenda and plan to launch a "productivity revolution" by capitalising on the technological innovations of the Fourth Industrial Revolution (Government of Japan, 2018). This includes a variety of digital technologies, such as the Internet of Things and advanced robotics, industrial biotechnology, new materials and nanotechnology. The confluence of digital technologies is driving the transformation of industrial production and has the potential to significantly boost productivity and mitigate the impact of a shrinking labour force (OECD, 2017d). Lifelong learning is needed to prepare for jobs that have not yet been created and to use technologies that have not yet been invented. The digital transformation requires workers 
to be increasingly flexible in order to adapt to new or different tasks and to be more mobile across occupations (Bechichi et al., 2018). In many countries, digitalisation and automation face opposition due to concern about the risks of job losses and the disruption of economic and social structures. However, in Japan, the labour shortage removes this obstacle to digitalisation.

Even so, digitalisation may widen inequality through job polarisation and productivity gaps. A study based on occupational titles finds that almost half of all jobs are at risk of being eliminated by automation technology within 20 years (Frey and Osborne, 2017). An OECD study based on the task content of individual jobs predicts that around $14 \%$ of jobs in OECD countries are at a high risk of automation (Nedelkoska and Quintini, 2018). An additional $32 \%$ of jobs, which are characterised by many routine tasks, may experience radical changes in how they are performed. However, jobs characterised by either highskilled tasks requiring problem-solving and interpersonal skills or low-skilled non-routine tasks, such as caring and personal services, will be harder to automate. Consequently, digitalisation may result in job polarisation and "technological unemployment" if workers cannot adapt to changes induced by technological progress. In addition, another OECD study finds evidence that digitalisation in European countries has a positive impact on productivity but the gains are distributed unevenly across firms, suggesting complementarities between digital technologies and skills, organisation, and intangibles (Gal et al., 2019). On the positive side, digitalisation may enhance well-being by reducing long working hours and improving work-life balance.

As technological change accelerates, the government and firms need to enable workers of all ages to maintain and acquire appropriate skills through an effective system of lifelong vocational training (OECD, 2018a), thereby extending careers and mitigating the impact of population decline. More than two-thirds of Japanese workers believe that they need further training, double the OECD average. However, the OECD Survey of Adult Skills finds that participation in lifelong learning in Japan is in the bottom quartile of countries in the Survey. Spending on institutional training is the fifth lowest in the OECD, as the rise in the proportion of non-regular workers from $15 \%$ in 1984 to nearly $40 \%$ has reduced the incentive for such investments. A key challenge is that skill training provided by workplaces and educational institutions often does not reach workers in jobs at high risk of automation, typically non-regular workers in routine jobs. Participation in training in Japan is thus lower for non-regular workers and those who are less skilled, and it drops with age (OECD, 2018a). The share of firms in Japan providing on-the-job training for regular employees in 2015 was $62 \%$, but only $31 \%$ for non-regular employees (OECD, 2018f). Consequently, the share of older Japanese workers participating in job-related training is among the lowest in the OECD (Figure 12). Abolishing the right of firms to set mandatory retirement would increase incentives for lifelong learning and for job mobility.

Traditionally, institutions of higher education in Japan have focused on general education, leaving companies responsible for providing job-specific skills. Tertiary institutions emphasising vocational training have seen a decline in enrolments, as students shift to university (Jones, 2011). The government has realised the importance of enhancing the vocational training role of universities by increasing their links to the business sector. In April 2019, Japan will launch a system of professional and vocational universities (PVU) and professional and vocational junior colleges (PVJC). In contrast to conventional universities, these new institutions are asked to provide practical, creative vocational education in close cooperation with industry, including long-term firm-based training. In addition, as part of the 2018-22 National Basic Plan for the Promotion of Education, the government aims to improve access to adult learning through new programmes by 
encouraging universities to explore opportunities to expand lifelong learning. Tertiary education institutions are accepting an increasing number of older students as the number of university-aged youth declines. However, some of their lifelong learning initiatives focus on qualifications traditionally developed for younger students, which cover a broad range of topics and take considerable time. In short, traditional tertiary education programmes are unlikely to meet the urgent needs of employers (OECD, 2018a).

Figure 12. Participation in job-related training is low for older Japanese

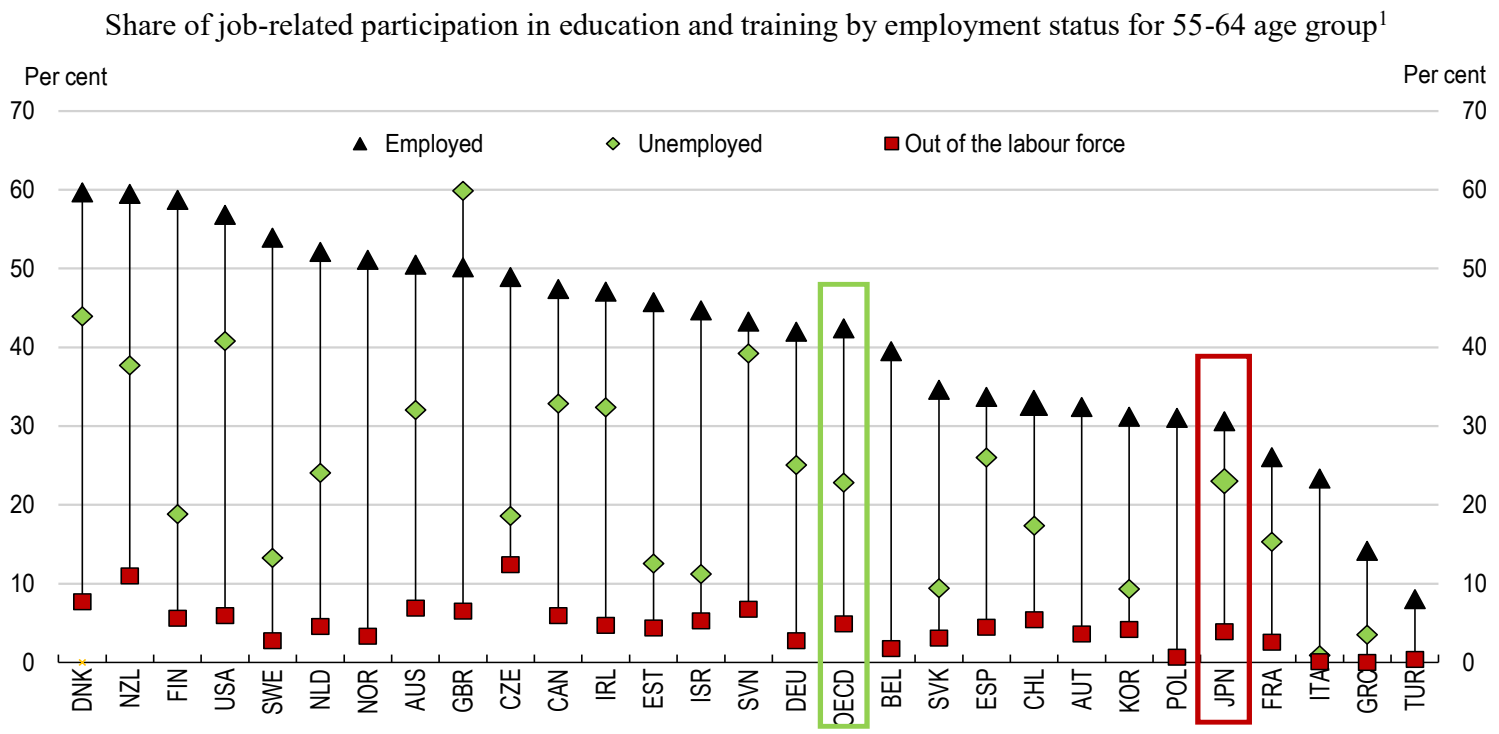

1. For 2015 for Chile, Greece, Israel, New Zealand, Slovenia and Turkey and 2012 for the other countries. Source: OECD (2018f).

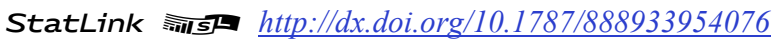

Japan needs to overcome three major obstacles to expanding lifelong learning:

- The lack of relevance of lifelong learning: Japanese adults participating in lifelong learning were less likely than those in any other country to rate their learning as useful for their work (Figure 13). Lifelong learning needs to target key competencies that match labour market needs, although identifying the key skills in the digital economy is difficult.

- Time constraints: Many Japanese workers work long hours. Lifelong learning has a high opportunity cost, given the high value of leisure time in Japan. With long working hours and limited time for study, shorter and more flexible modules of lifelong learning would be more effective than traditional approaches at tertiary institutions. The development of micro-credentials and nano-qualifications offer opportunities to close skill gaps quickly.

- Financial constraints: The proportion of Japanese workers engaged in lifelong learning who were supported financially by their employer was in the lowest quartile of surveyed countries in 2015. Given that the benefits of lifelong learning are shared by workers, employers and society, the cost should be split between those participating in the learning, companies and the government. Otherwise, Japan's "working poor" population, primarily non-regular and low-skilled workers, risk being excluded from lifelong learning (OECD, 2018a). 


\section{Figure 13. Share of workers who find education and training useful for their job is low in} Japan

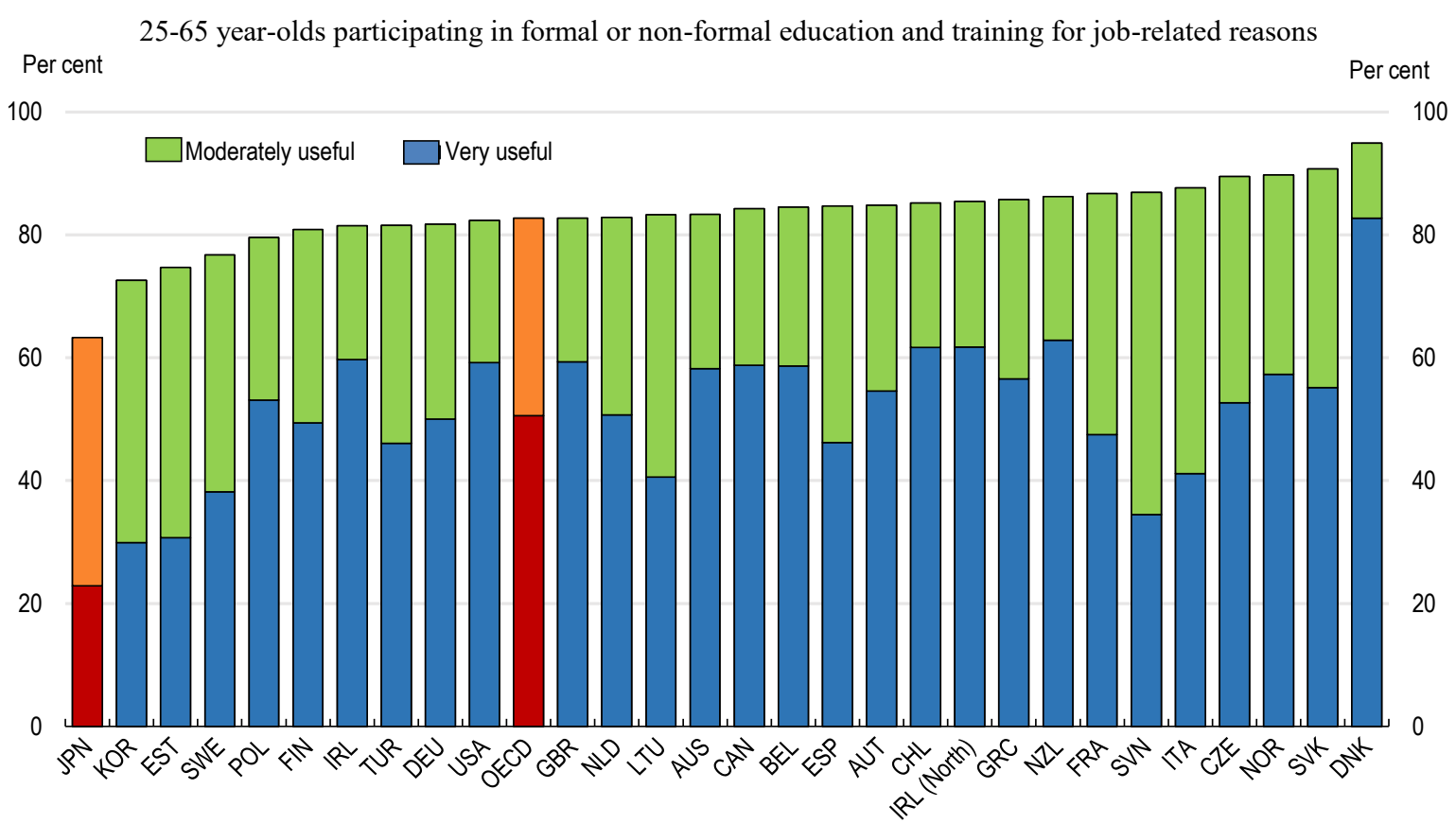

Note: For 2015 for Chile, Greece, Lithuania, New Zealand, Slovenia and Turkey are from 2015, and 2012 for the other countries.

Source: OECD (2018a).

StatLink त्ञाजा http://dx.doi.org/10.1787/888933954095

\section{Providing effective job placement services}

Effective job placement services would help older workers shift to a second career. Persons who are not searching for a job but express a desire to work account for $10 \%$ of the inactive population aged 55-64 and 3\% of those aged 65-74. The 2016 Labour Force Survey found that almost $40 \%$ of the people in this group in the 55-64 age group and 57\% in the $65-74$ age group were not looking for work because they think that there is no prospect of finding a job despite Japan's severe labour shortages (Figure 14). Other factors, such as poor health and the need to care for family members, are less important (OECD, 2018f). Total spending on labour market policies in Japan, including job training and placement services, was the third lowest in the OECD in 2016 as a share of GDP.

\section{Improving working conditions}

Job quality is an important determinant of well-being for older workers and plays an important role in their decisions of whether to continue working or to take up work. Promoting good working conditions at all ages is essential to protect health. In addition, it enhances the ability and motivation to continue working at an older age. It is also essential to ensure that working conditions are adapted to meet the needs of older persons, as well as those with responsibility as caregivers. Poor working conditions have a compounding adverse effect on health over a person's career. Those with poor health tend to work and earn less, which limits their chance to accumulate human capital and extend their working life (OECD, 2018f). Having good physical and mental health is crucial to allow older workers to stay in the labour market. Reducing working time is a key aspect of appropriate working conditions (see below). 
Figure 14. Reasons why some inactive persons who wish to work do not search for jobs

Percent within each age group of inactive persons wishing to work in 2016

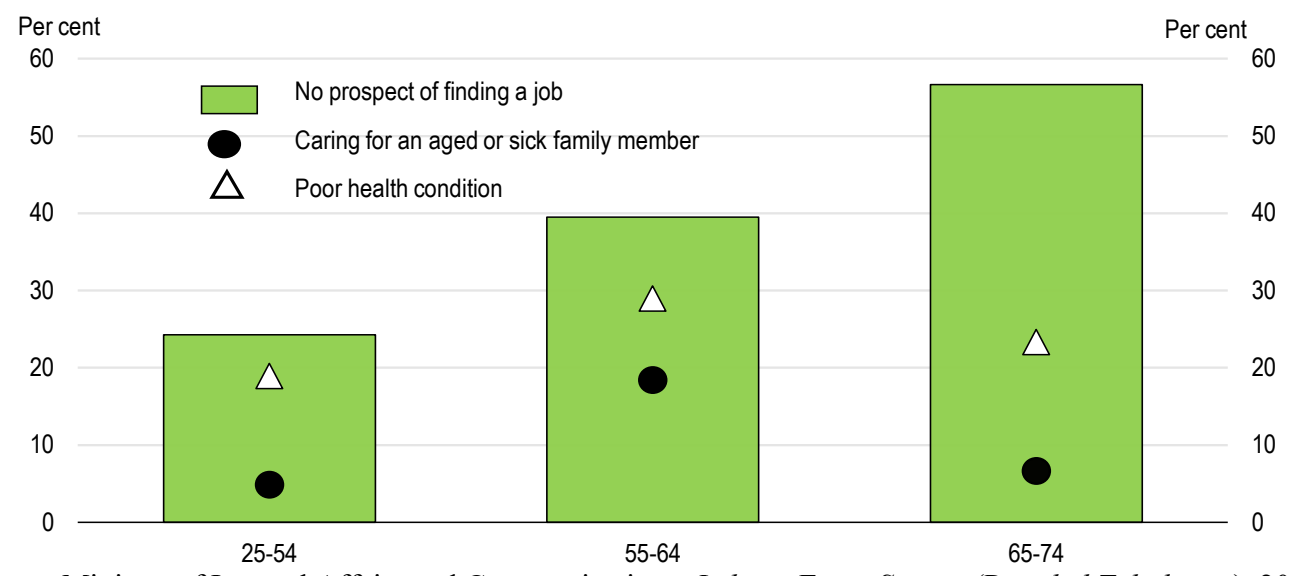

Source: Ministry of Internal Affairs and Communications, Labour Force Survey (Detailed Tabulation), 2016.

StatLink הत्lsh http://dx.doi.org/10.1787/888933954114

\section{Reducing obstacles to the employment of women}

The share of dual-income households doubled from around 6 million in 1980 to more than 12 million by 2018 (Figure 15). Japan has added 2.5 million women to the labour force since 2013 , boosting the female employment rate from $60.7 \%$ in 2012 to $69.6 \%$ in 2018 , above the OECD median of $67.5 \%$ (Figure 16). The increase was primarily a result of labour shortages resulting from demographic factors, although government policies notably the increase in childcare capacity since 2013 - has also contributed.

\section{Figure 15. Dual-income households now account for two-thirds of all households}

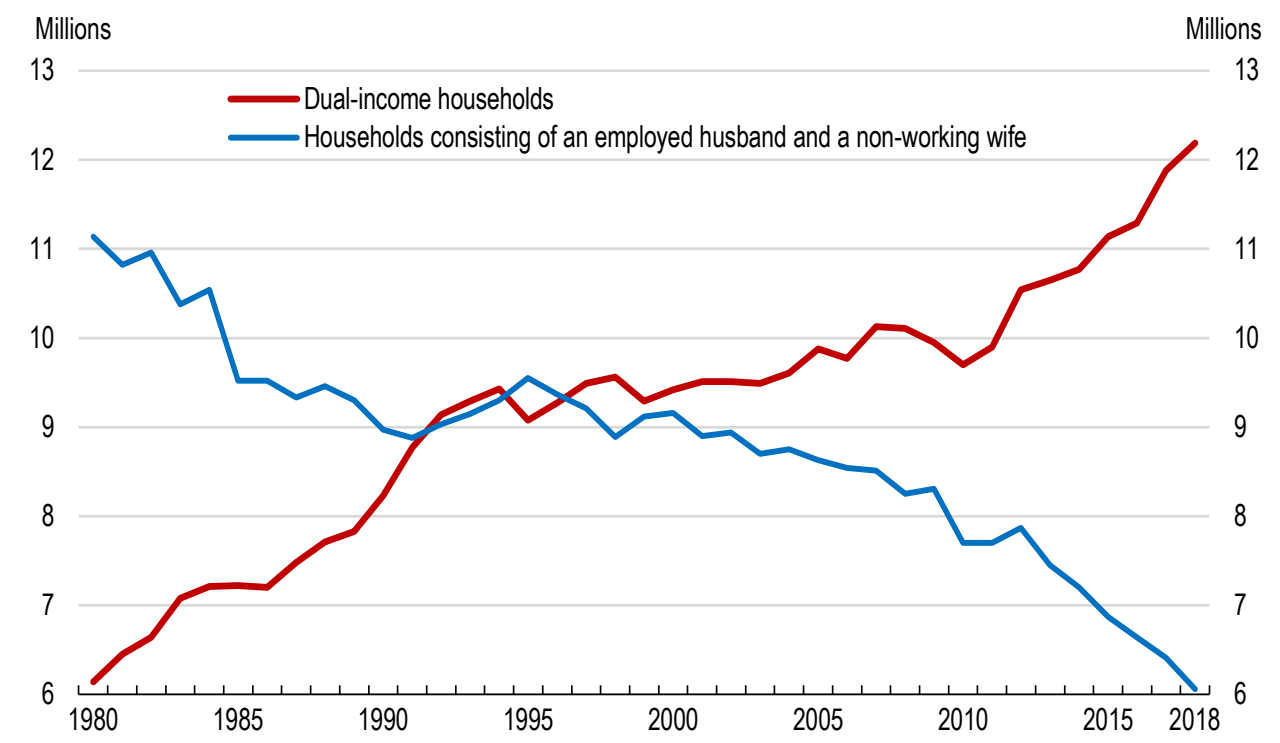

Source: Ministry of Internal Affairs and Communications, Special Survey of the Labour Force Survey from 1980 to 2001 and Labour Force Survey (Detailed Tabulation) since 2002 (annual average). 
Figure 16. Female employment has increased, but gender inequality remains high

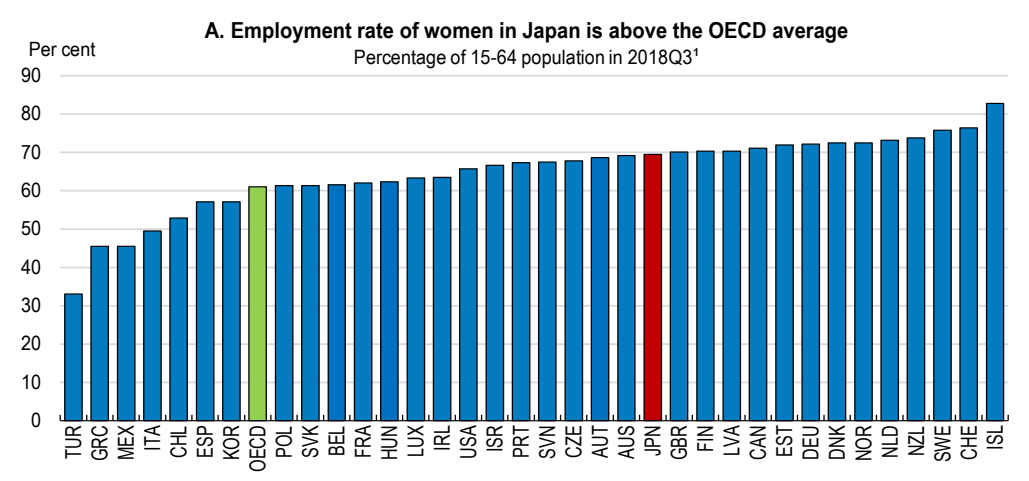

B. The gender gap in employment rates in Japan has narrowed to the OECD average
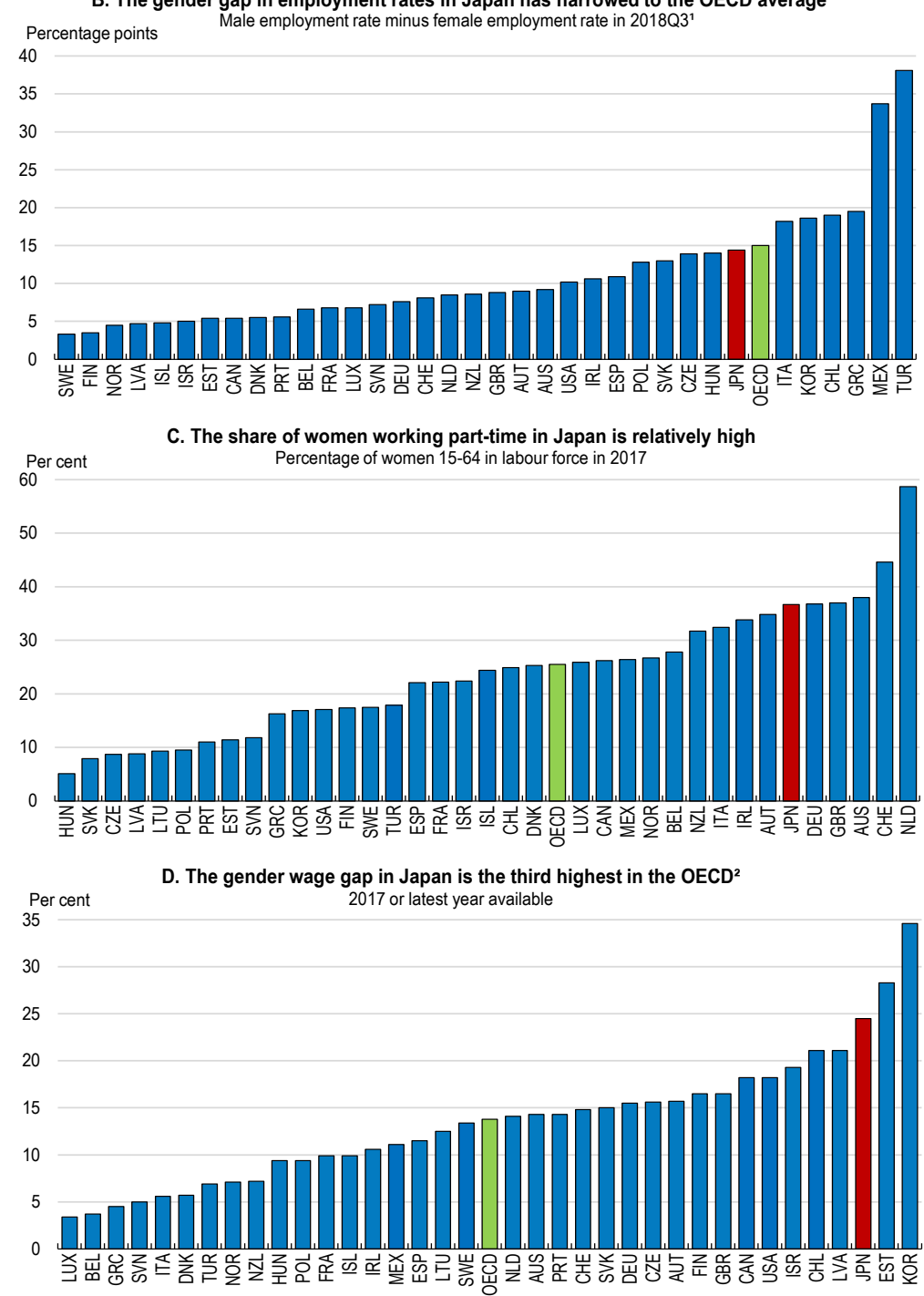

1. The year 2018 for Japan.

2. The difference between median earnings of men and women relative to the median earnings of men who are full-time employees.

Source: OECD Gender database.

StatLink त्ताज्य http://dx.doi.org/10.1787/888933954152 
However, the gains in female employment mask significant gender inequality:

- The female employment rate was 14 percentage points below the rate for men in 2018, slightly below the OECD average (Figure 16, Panel B).

- Non-regular jobs, primarily part-time positions, accounted for about half of the rise in female employment since 2013. Female regular employees who leave the labour force to care for children typically return to the labour market as non-regular workers. Indeed, $61 \%$ of women in the $25-34$ age group in 2017 were regular workers, compared to $41 \%$ in the $45-54$ age group. Overall, only $45 \%$ of women were regular workers, compared to $78 \%$ for men. Consequently, women account for two-thirds of non-regular workers. In Japan, the share of women working parttime (less than 30 hours per week) was $37 \%$ in 2017, well above the $25 \%$ OECD average and the sixth highest in the OECD (Panel C).

- The concentration of women in low-paying non-regular jobs contributes to a gender wage gap of $25 \%$, the third highest in the OECD (Panel D), although it has declined from $33 \%$ in 2005 .

- Women's share of leadership roles remains low (see below).

Raising the participation of women in the labour market is an important element of coping with a declining population. If the female participation rate were to converge to the male rate by 2050 , the labour force would be $5 \%$ higher than with unchanged participation rates. This section focuses on strategies to enhance the employment of women in high-quality jobs, namely improving work-life balance, ensuring high quality and affordable childcare and long-term care for the elderly, reforming the tax and benefit system to remove disincentives to work for secondary earners and fighting discrimination and gender stereotypes. Breaking down labour market dualism, which is discussed in a later section, is also a key priority to address gender inequality and raise the quality of female employment.

\section{Improving work-life balance}

Japan ranks in the bottom fifth in the OECD in work-life balance, reflecting long working hours. Working hours in Japan were among the longest in the OECD area for many decades, but have fallen by $16 \%$ since 1990 to an average of 1710 hours per year, slightly below the OECD average. However, the decline was primarily a result of a substantial increase in the number of non-regular workers with relatively short working hours. In households with a married couple, the change in average working hours for husbands and wives combined over the past 30 years is quite small (Figure 17). The effects of legislative measures that shortened the statutory working week from 46 hours in 1988 to 40 hours in 1997 appear to have been minimal.

Japan's labour market culture has fostered a chronic and voluntary underuse of paid time off. In 2017, private-sector workers took only 51\% (nine days) of their paid vacation time. The government in 2010 set a goal of $70 \%$ by 2020 . Another key problem is the proportion of men working long hours. In 2017, 12\% worked 60 hours a week or more, the fifth highest in the OECD, compared to only 3\% for women (Figure 18). A 2016 government survey found that $23 \%$ of firms had full-time employees who worked more than 80 hours of overtime per month (Ministry of Health, Labour and Welfare, 2017b). Many Japanese workers would benefit from shorter working hours. 
Figure 17. Working hours in Japan have changed little during the past 30 years

In households with a married couple, with both employed

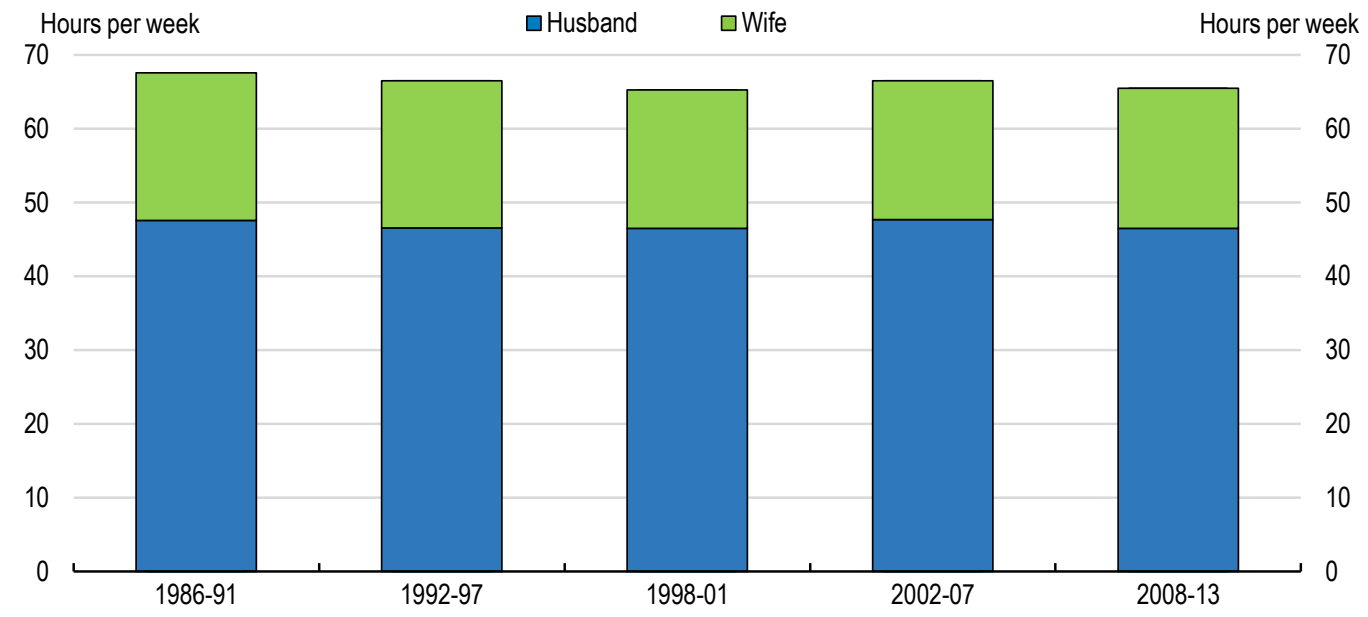

Source: Nagamachi and Yugami (2015).

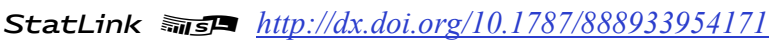

A lack of work-life balance has a strong negative influence on workers, as well as on their families. Long hours for men leave women devoting nearly four hours a day to housework and childcare compared to less than one hour for men. The gender gap in unpaid work in Japan is thus 183 minutes per day, the fourth longest in the OECD (Figure 18, Panel B). The commitment of men to their jobs also makes parental leave less attractive, even though it is the most generous in the OECD (along with Korea). Both men and women are entitled to one year of parental leave paid at $67 \%$ of earnings (up to a threshold) for the first 180 calendar days and $50 \%$ for the remainder until their children reach age one. Despite an upward trend, the share of men taking parental leave was 5\% in 2017, compared to $83 \%$ for women (Panel C). Consequently, men account for about $7 \%$ of parental leave users, compared to up to $40 \%$ or more in some Nordic countries and Portugal (OECD, 2018d). One positive step is the 2017 revision of the Childcare and Family Care Leave Law to allow caregivers to apply for an exemption from overtime work.

The 2018 work style reform bill introduced mandatory limits on overtime hours for the first time in Japan. Previously, employers could demand unlimited overtime work if they had a written agreement with their employees. However, nearly half of firms with less than 30 workers do not have a labour-management agreement on overtime and holiday work (Ministry of Health, Labour and Welfare, 2013). Under the new legislation, which will take effect in 2019 for large firms and in 2020 for SMEs, overtime work is limited to 45 hours per month and 360 hours per year in principle. However, employers with an agreement with their workers can require them to work up to 100 hours of overtime per month, as long as they do not exceed an annual limit of 720 hours. Firms that violate these limits face a penalty of up to JPY 300000 (USD 2 660) per worker exceeding the limit. 
Figure 18. Long working hours in Japan have negative consequences

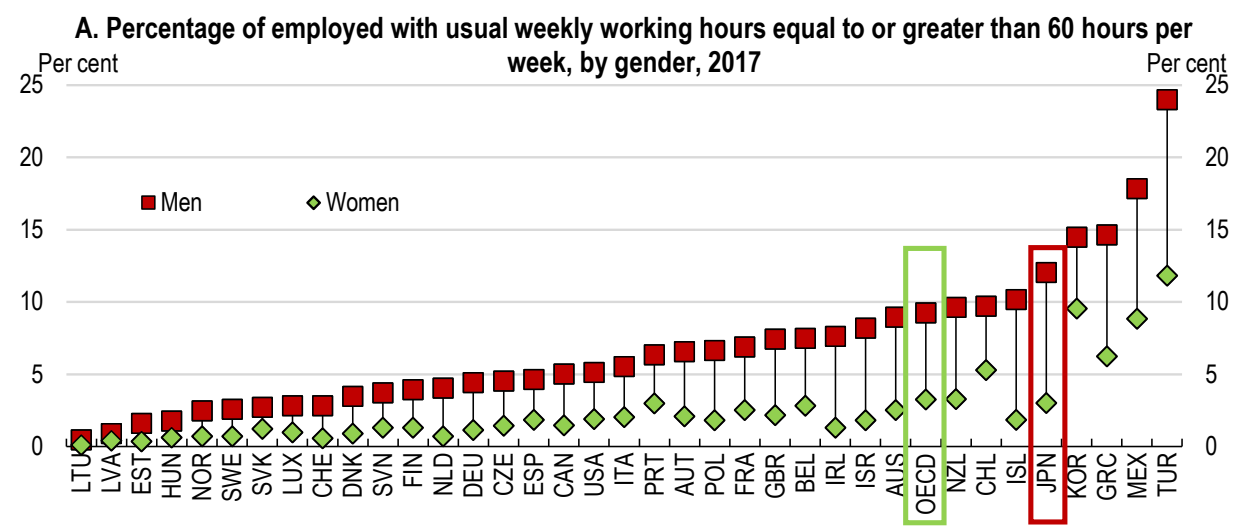

B. Japanese women spend much more time in household work than men

Gender gap in minutes spent per day on unpaid work, female minus male, 15-64 year-olds

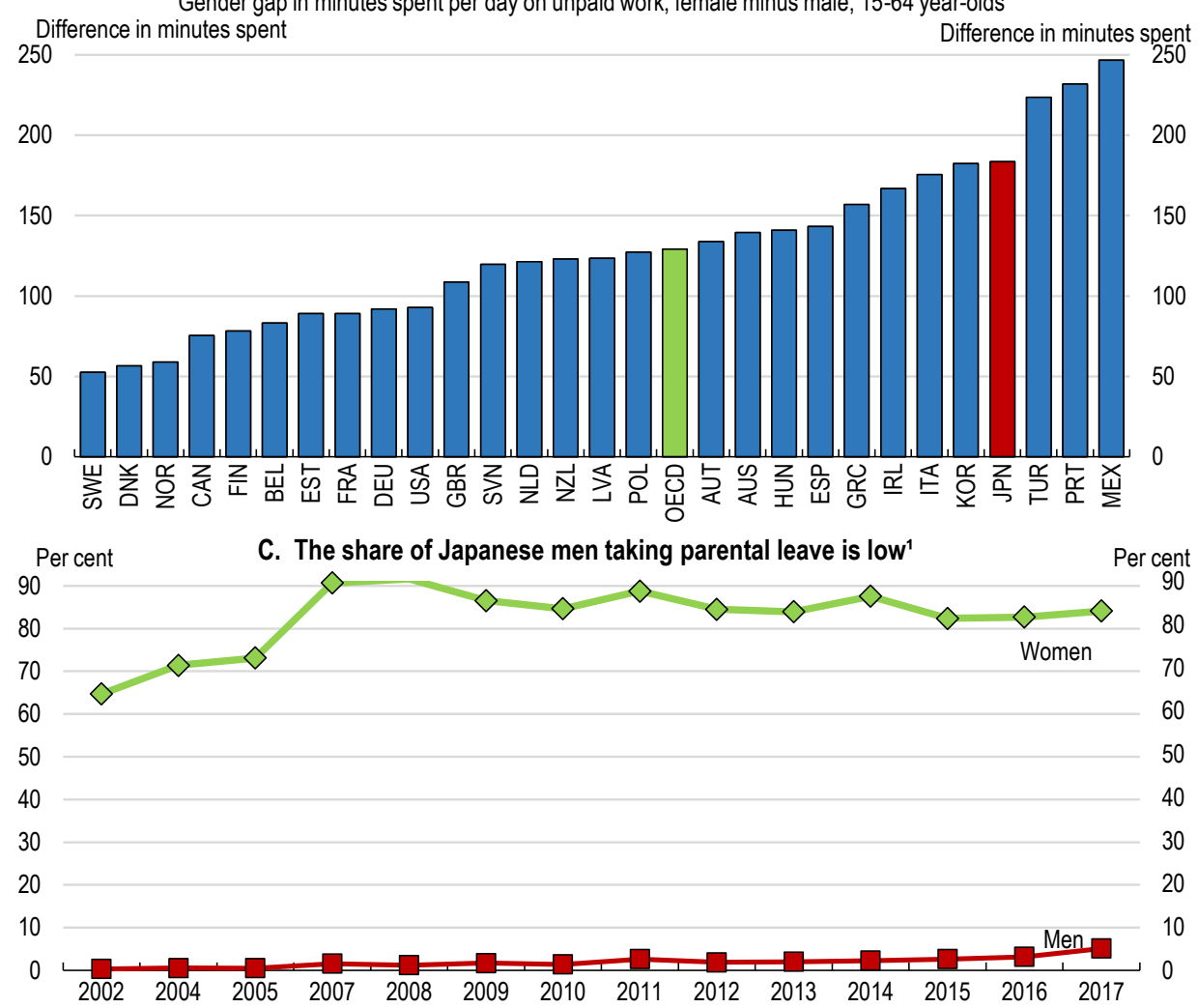

1. For women, those taking parental leave as a share of the total number of female workers with new-borns. For men, those taking parental leave as a share of the total number of male workers with spouses who have recently given birth.

Source: OECD Employment database; OECD Gender database; and Ministry of Health, Labour and Welfare, Basic Survey of Gender Equality in Employment Management.

\section{StatLink הत्ञात http://dx.doi.org/10.1787/888933954190}

While work style reform goes in the right direction, it is unclear whether it will effectively change Japan's long working-hour culture. Given the low fines and more generous overtime limits for firms with a workplace agreement, the new law relies primarily on government recommendations to change social norms. One concern is that overtime work 
can exceed 80 hours a month, the level at which karoshi (death by overwork) becomes a serious concern. Work style reform also established a scheme that exempts highly specialised professional workers from the overtime limits. It is essential to ensure that employers strictly comply with the obligation to provide such workers with at least 104 days off from work per year and at least four days per four weeks, in addition to introducing measures to protect their health. Pressure by firms on workers to maintain their output despite shorter overtime hours made jitan-harasumento (short-time harassment) one of the most common new words in Japan in 2018 (Japan Times, 2018).

The government should also consider establishing a mandatory scheme applicable to all workers that requires rest periods between periods of work (interval-time regulation). The Overtime Work Improvement Subsidy established in FY 2017 encourages the introduction of rest periods in SMEs and the recently revised Act on Special Measures for Improvement of Working Hours Arrangements requires all firms to make "efforts" to establish an interval time. In addition, the government provides a subsidy if the interval time is at least nine hours. However, relying on voluntary efforts by firms and monetary incentives may not be sufficient. In 2017 , only $1.4 \%$ of firms introduced this system. Taking into account average commuting time for employees in Japan, which in Japan is the third highest among OECD countries at 48 minutes per day, it would be beneficial to have an interval time of 11 hours, as in the European Union. A mandatory interval-time scheme that considers commuting time is necessary to create better work-life balance. Such a system should be applied to high-skilled professionals who are exempted from overtime regulations. Finally, the Childcare and Family Care Leave Law should be better enforced to increase working-time flexibility (OECD, 2018f).

Expanding the use of teleworking would also improve work-life balance, particularly given long commuting times, and reduce environmental and congestion costs. In $2015,16 \%$ of Japanese companies allowed employees to telework occasionally and only $4 \%$ of workers telecommuted once a week according to a government survey. In 2017, the government set a target of increasing that number to $10 \%$ by 2020 and designated 24 July as "Telework Day" to encourage people to work from home. The government is also encouraging teleworking in the public sector: in FY 2017, 12.4\% of officials, primarily those responsible for clearly defined or divisible tasks, such as accounting, payroll, drafting documents and processing email inquiries, experienced teleworking (Cabinet Secretariat, 2018). The most frequently cited reason that companies give for not introducing teleworking is that they cannot find tasks suitable for it. In Japan, companies do not provide clear job descriptions and work is not always divisible into individual tasks. Companies rely on a culture of meetings and face-to-face relationships, which make teleworking difficult. Changes in business practices are therefore needed to increase the use of teleworking.

\section{Providing high-quality, affordable childcare}

A government survey reported that of the 500000 workers who left jobs over 2007-12, $60 \%$ said that the main reason was that "it is difficult to balance work and family care". The share of women who were employed at the time of their first pregnancy rose from $61 \%$ in $1985-89$ to $72 \%$ in 2010-14 (Figure 19). Moreover, among those who were employed, the share of those who chose to continue working rose from $39 \%$ to $53 \%$ over the same period. Still, nearly half of women withdraw from the labour market after the birth of their first child. Most women re-entering the labour force find non-regular employment instead of regular employment. The decision on whether to remain in the labour force after having a child depends in part on the availability of affordable, high-quality childcare, as well as other factors such as work-life balance. 
Figure 19. The share of women remaining in the labour force after having children

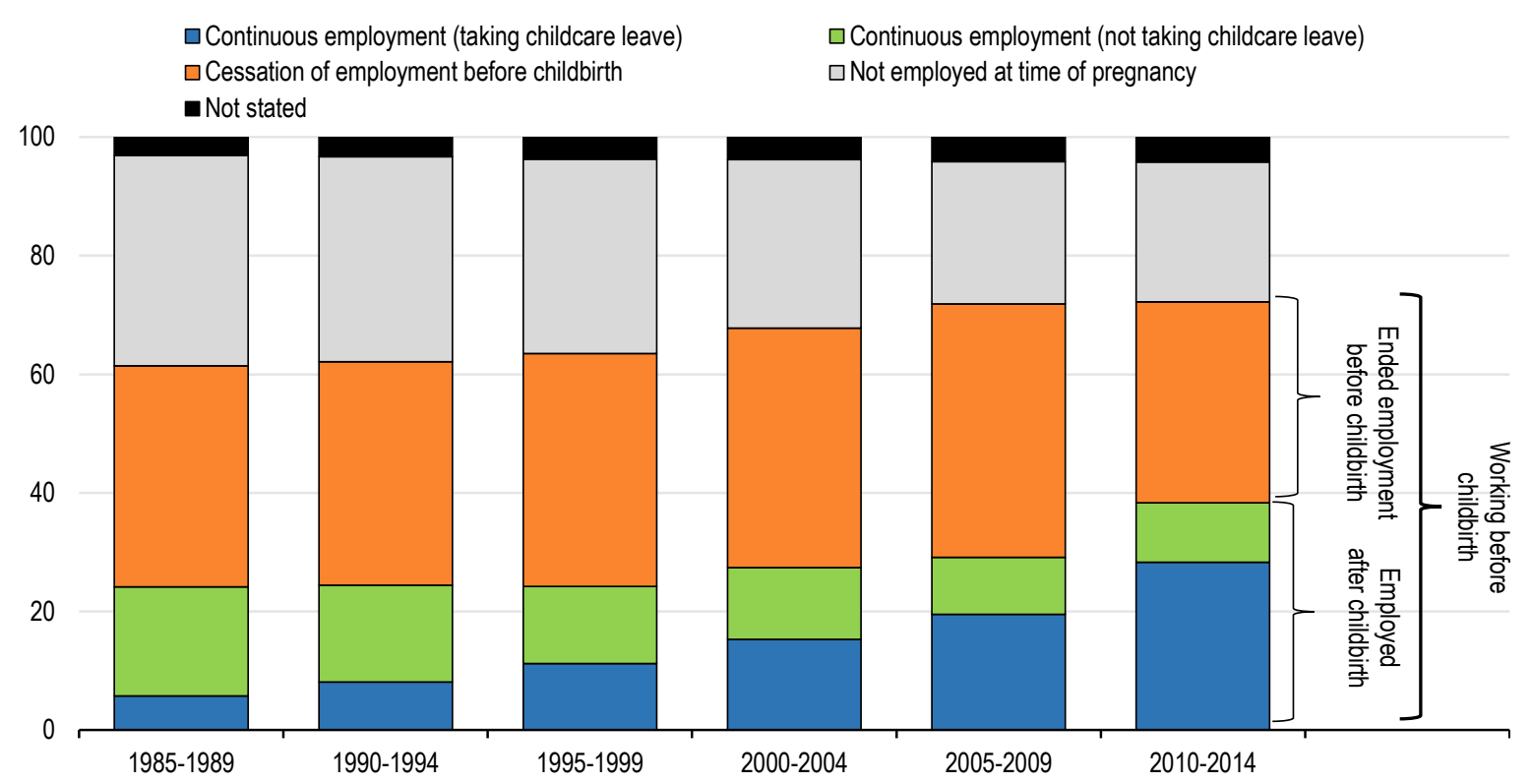

Source: Cabinet Office (2018).

StatLink त्ञाज् http://dx.doi.org/10.1787/888933954209

Japan added 0.53 million childcare places over FY 2013-17, with the aim of eliminating waiting lists by March 2018 (Figure 20). However, the waiting list was close to 20000 in 2018 , as the number of women in the labour force increased sharply. Parents who cannot find childcare are allowed to take a second year of parental leave from work. If the children in these families were included, the waiting list would be around 90000 (Mainichi Newspaper, 2017). Moreover, many parents who realise that it is unlikely that their child will be accepted by a childcare centre may not bother to apply, suggesting that the shortage is actually much higher (Unayama, 2017). Childcare capacity varies widely between prefectures, with shortages observed primarily in urban areas, such as Tokyo and Osaka (Figure 21). Childcare capacity per child in Kochi prefecture is more than three time higher than in Saitama prefecture, which is close to Tokyo. Moreover, the options for in-home childcare in Japan are relatively limited by constraints on foreign workers.

From a perspective of female employment, increasing the capacity of childcare should be the priority. Female employment is low in prefectures with less childcare capacity. In the 2015 Census, the prefectures with the lowest labour force participation rates for women aged 35-39 were Tokyo (55.7\%), Kanagawa (58.5\%) and Osaka (60.6\%), which have limited childcare capacity. Childcare capacity increases should be focused on urban areas and on children aged 0 to 2, who account for $90 \%$ of the children on the waiting list. Such care is relatively expensive, as there must be one care giver for every six children, compared to one for 20 children aged 3 to 5 . To increase capacity and eliminate waiting lists, public childcare centres should be supplemented by private institutions. First, entry by corporations, which is discouraged by policies such as a reduced corporate income tax and subsidies for social welfare organisations, should be facilitated. Second, quality regulations, such as the minimum area for childcare centres, set by some local governments exceed national standards. The rationale for more stringent standards, which limit entry by new suppliers, should be reviewed (Yashiro, 2016). 
Figure 20. Waiting lists remain long despite rising childcare capacity

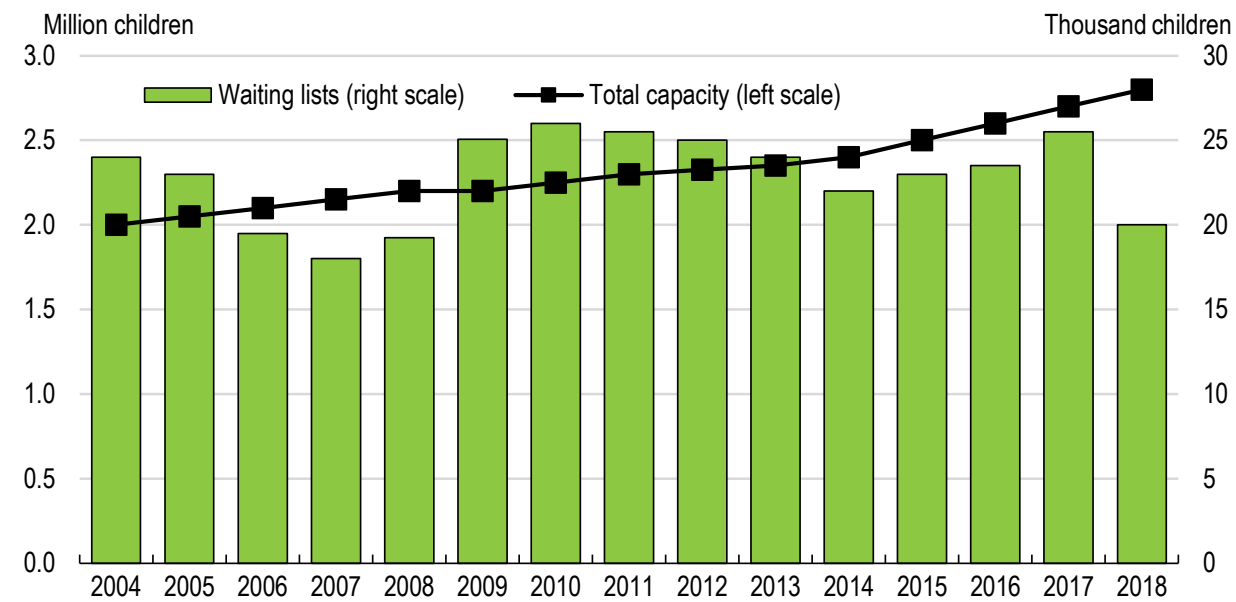

Source: Ministry of Health, Labour and Welfare.

StatLink 제내 http://dx.doi.org/10.1787/888933954228

Figure 21. Childcare capacity is limited in major urban areas

Capacity in accredited childcare centres relative to the number of children ${ }^{1}$ by prefecture in 2016

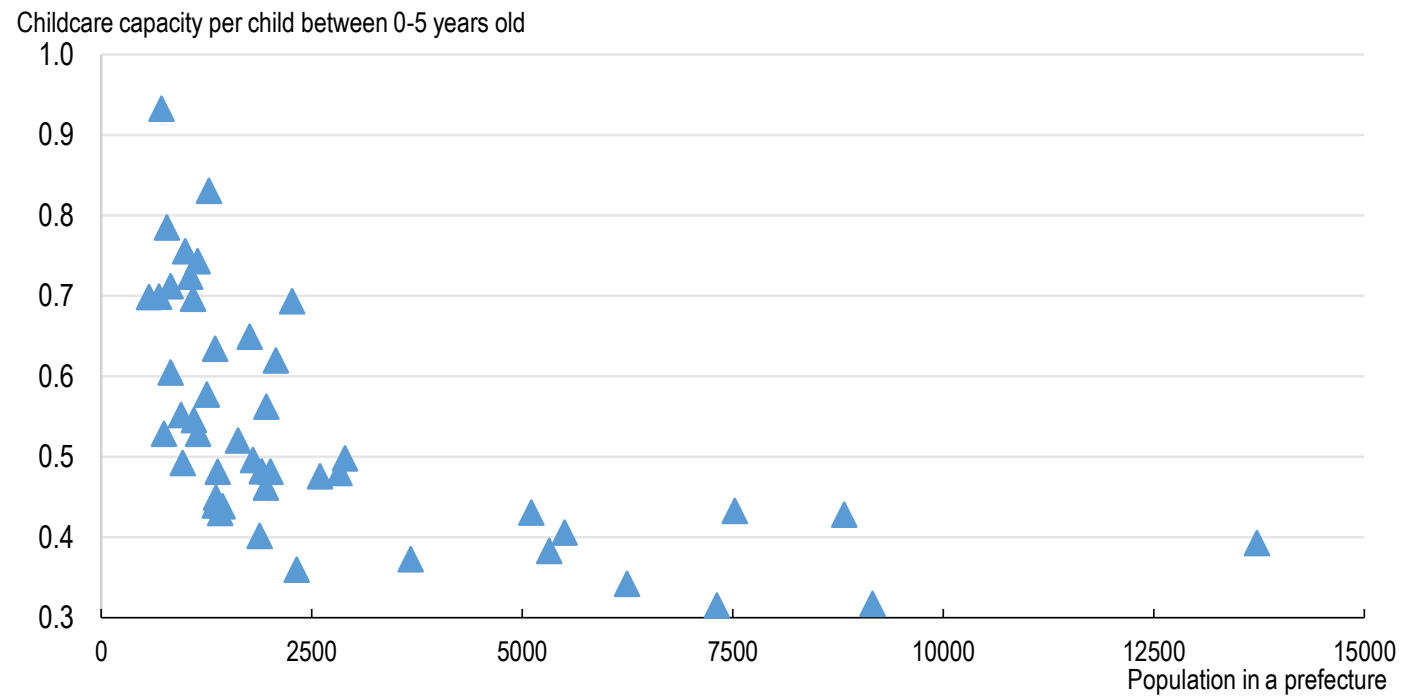

1. Number of children aged 0-5. Number of children aged 5 is calculated as one-fifth of children aged 5-9. Source: Ministry of Health, Labour and Welfare; Ministry of Internal Affairs and Communications; and OECD calculations.

StatLink 세내 http://dx.doi.org/10.1787/888933954247

In the 2017 "New Economic Policy Package", the government promised to eliminate waiting lists by March 2021 by adding 320000 childcare places. This number is based on the estimated increase in the employment rate of women. Even with the planned expansion, eliminating childcare waiting lists is a big challenge, given latent demand. The government will introduce free childcare and kindergarten for children aged 3 to 5 in October 2019. For children aged 0 to 2, childcare is only free for low-income families who are exempt from the municipal residence tax. The hike in the consumption tax rate from $8 \%$ to $10 \%$ in 
October 2019 is to finance the new policy. Moreover, free childcare and kindergarten will not substantially boost enrolment, given that more than $91 \%$ of children aged 3 to 5 are already enrolled compared to the OECD average of $85 \%$, and thus will not have a significant impact on employment. Its main effect will be to shift the burden of paying for childcare (which is already reduced by subsidies to childcare centres) and kindergarten from families to taxpayers. The government hopes that this policy will boost the birth rate, which was 1.4 in 2018.

Whether childcare centres are public or private, the shortage of childcare workers is a major obstacle. The job openings-to-applicants ratio for childcare workers is 2.3, compared to the nationwide average of around 1.6, and the government expects the ratio to remain high. In Tokyo, the ratio exceeds five. It is estimated that as many as 0.84 million persons who are certified to work in childcare are not working in that field, with low pay cited as the most important reason (Weathers, 2016). Indeed, more than half of childcare workers in the public sector are non-regular workers. Meeting shortages requires inducing qualified workers to return to childcare through better pay and working conditions. In addition, workers in related fields, such as nursing, could be allowed to work in childcare centres (2017 OECD Economic Survey of Japan).

The lack of after-school care has become a serious problem. The end of childcare services when children enrol in primary school has become known as the "first-grade barrier". Around $40 \%$ of the nationwide waiting list for after-school care is in Tokyo, Saitama, and Chiba (Sankei, 2018). Addressing this shortage should be a priority.

\section{Ensuring that women do not have to leave their jobs to care for elderly relatives}

Population ageing also reduces the labour force as workers, primarily women, withdraw to care for elderly relatives. Since 2010 , there has been a considerable increase in the number of workers quitting their jobs to provide long-term care (Figure 22). One of the objectives of the 2016 "Plan for Dynamic Engagement of All Citizens" is that "No one will be forced to leave their jobs to provide nursing care". To achieve this target, the government intends to increase long-term care capacity for the elderly by at least 0.5 million by the early $2020 \mathrm{~s}$. It projects that 2.16 million long-term caregivers will be needed by the early $2020 \mathrm{~s}$. In addition, the Child Care and Family Care Leave Act was revised in 2017 to offer more generous longterm care leave options. According to the Employment Status Survey in 2012, only 3.2\% of workers with long-term care responsibilities used leave (Ikeda, 2017). The revised Act allows workers to take long-term care leave three times for up to 93 days in total and exempts them from overtime work. It is important to increase awareness of long-term care leave entitlements among companies and workers and to provide incentives to promote its use.

\section{Reforming the tax system to remove disincentives to work for second earners}

Empirical evidence shows that second earners tend to be highly responsive to work disincentives. Tax and benefit systems that weaken second-earner work incentives have consequences for gender equity, efficiency and income inequality. Removing such disincentives can have a positive impact on employment and GDP and may reduce income inequality (Thomas and O'Reilly, 2016). Japan's tax system is based on individuals rather than families, an approach that tends to result in lower marginal tax rates on second earners. Japan's spousal deduction, originally introduced in 1961, exempted up to JPY 380000 (USD 3 382) from the main earner's taxable income, if the second earner earned less than JPY 1.03 million (USD 9 131). In addition, many private companies set JPY 1.03 million as the threshold for granting spousal benefits to their employees. These policies resulted in 
the "JPY 1.03 million ceiling", as most second earners aimed to keep their earnings below that threshold (Figure 23). Moreover, most of the deductions go to high-income households (Panel B). Of those earning less than the average wage (JPY 3.8 million in 2016), less than one-fifth benefited from the spousal deduction. The impact of the spousal deduction is magnified by the fact that second earners are eligible for the national pension without paying premiums if their income is below JPY 1.3 million.

Figure 22. The number of workers leaving jobs in Japan to provide long-term care is rising

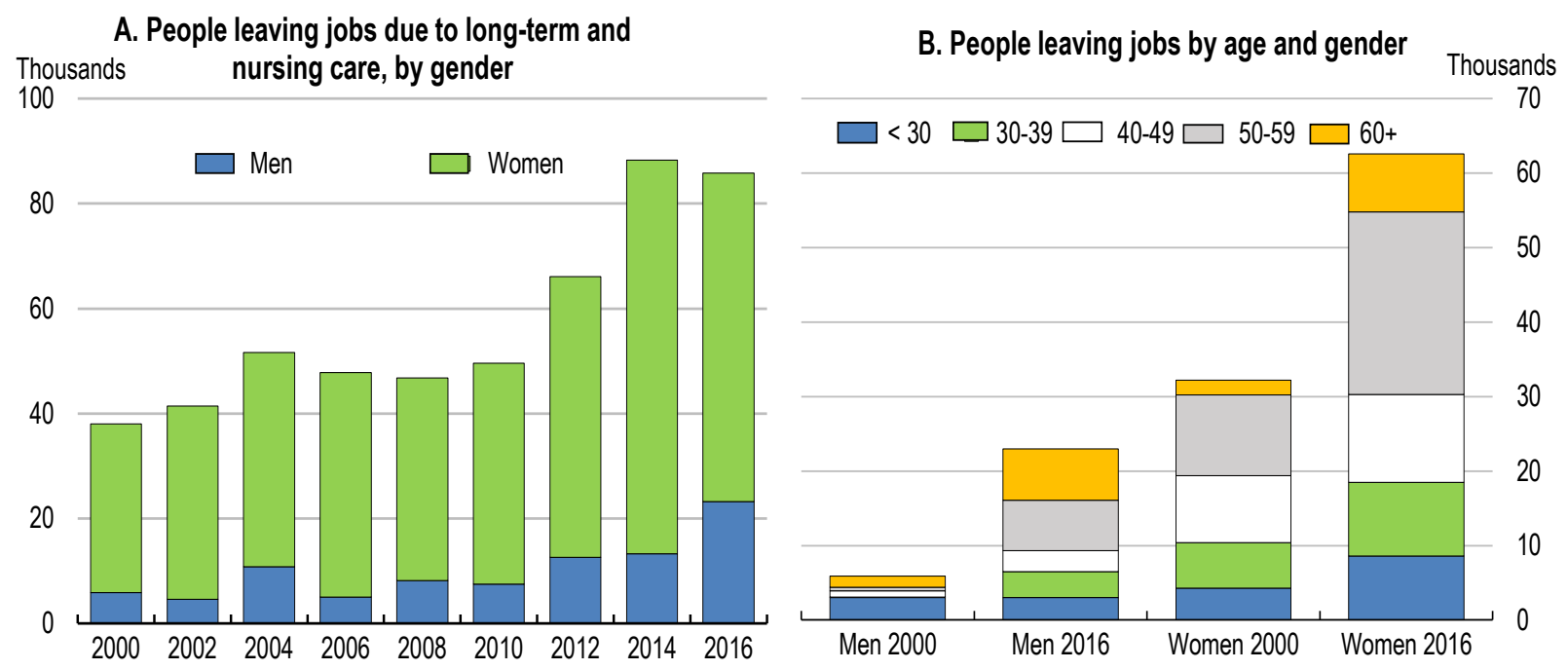

Source: OECD (2018f)

StatLink :-ints http://dx.doi.org/10.1787/888933954266

An OECD study (Thomas and O'Reilly, 2016) compares the incentives for a second earner to enter the labour force with those for a single person, assuming both have two children and earn $67 \%$ of the average wage. The average tax rate for the second earner $(23 \%)$ in 2015 was considerably above that on a single individual (13\%), reflecting the impact of the spousal deduction (Figure 24). Still, the level of the tax rate on second earners and the gap with single individuals was not high compared to the OECD average.

In addition to reducing the labour supply by encouraging second earners, who are often women, to work part-time, most of the spousal deductions go to high-income households, as noted above. In 2018, the income threshold for taking the deduction was raised to JPY 1.5 million yen (USD 13298 ). In addition, the deduction is no longer available to primary earners with income of more than JPY 12.2 million (USD 108 580). By allowing second earners to earn more without being subject to tax, the reform is expected to increase labour inputs by married women. In addition, Keidanren asked its member companies to consider reducing or eliminating spousal allowances in order to encourage more active workforce participation by married women. While these steps go in the right direction, the spousal deduction should be phased out (OECD, 2018d). This would be in line with the OECD Recommendation of the Council on Gender Equality in Education, Employment and Entrepreneurship, calling on countries to "design tax-benefit systems so that both parents have broadly similar financial incentives to work" (OECD, 2013b). 
Figure 23. The spousal deduction negatively affects female labour participation and equality

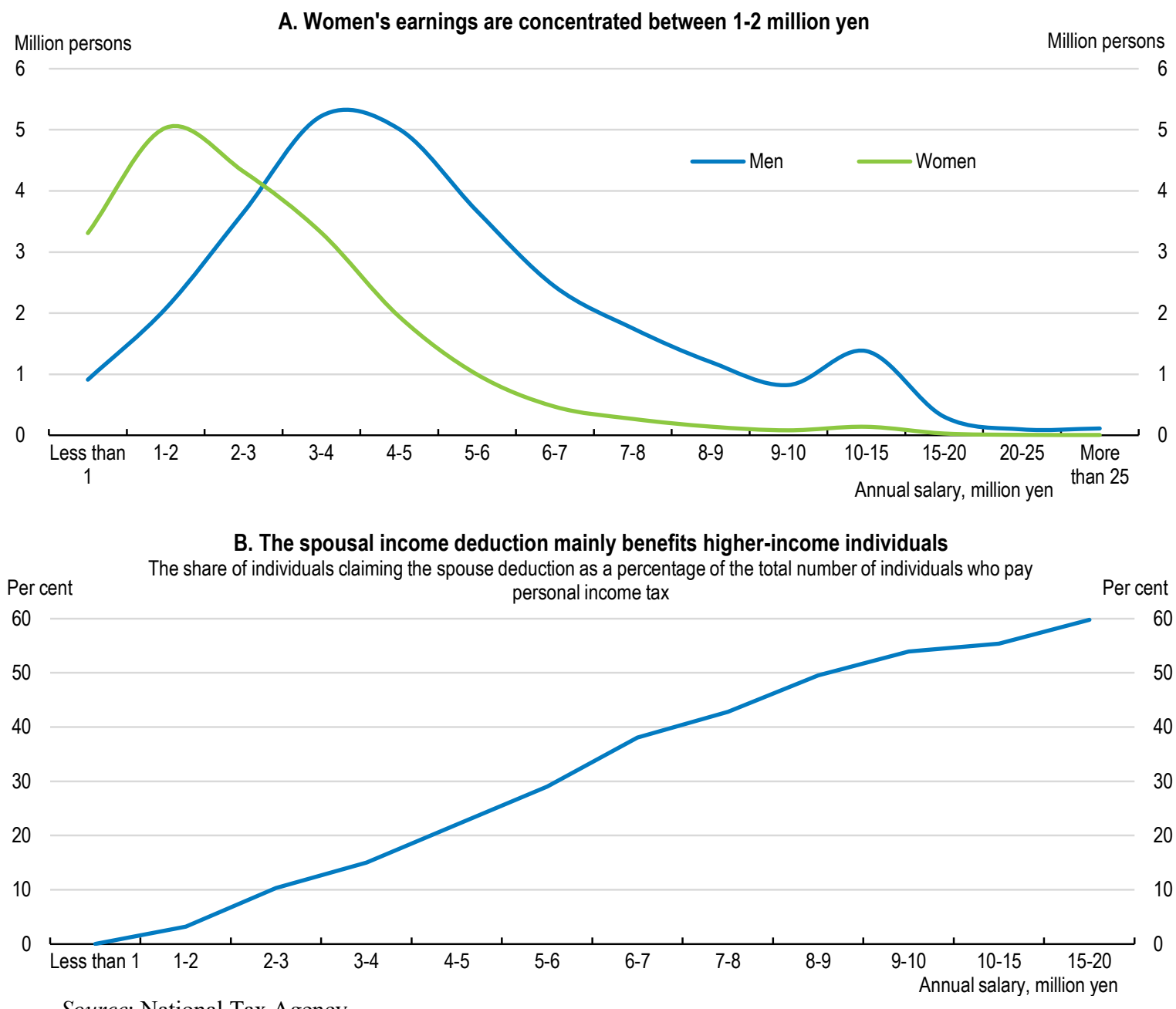

Source: National Tax Agency.

StatLink त्ञाजा http://dx.doi.org/10.1787/888933954285

\section{Enhancing women's role by reducing discrimination}

In 2003, Japan adopted a target of increasing the share of leadership roles held by women to $30 \%$. Prime Minister Abe promised in 2013 to create a society in which "all women can shine" and reaffirmed the $30 \%$ target for 2020 . He also stated in 2014 that women's social and economic advancement is necessary for economic growth. Keidanren has urged its members to make voluntary efforts toward improving women's status (Nemoto, 2016).

However, the share of women in leadership positions has remained low by international standards despite the rising education level of women and the implementation of gender equality laws. Women held only $13 \%$ of managerial positions in Japan in 2019, the second lowest in the OECD (Figure 25), suggesting a serious misallocation of human resources. Women accounted for only $4.9 \%$ of senior management positions in the central government in 2018 and $10.9 \%$ in the private sector in 2017 (Table 5). Moreover, women occupied only $5.3 \%$ of the seats on the boards of listed companies in 2017 (Figure 25, Panel B). Only 10\% of the members in Japan's lower house are women, compared to 26\% in France and 37\% 
in Germany (Panel C). Japan thus ranks 161st out of 193 countries in female political representation. Japan's ranking in the gender equality index by the World Economic Forum fell from $101^{\text {st }}$ in 2012 to $110^{\text {th }}$ in 2018.

Figure 24. Average tax rates tend to be higher on second earners than on individuals

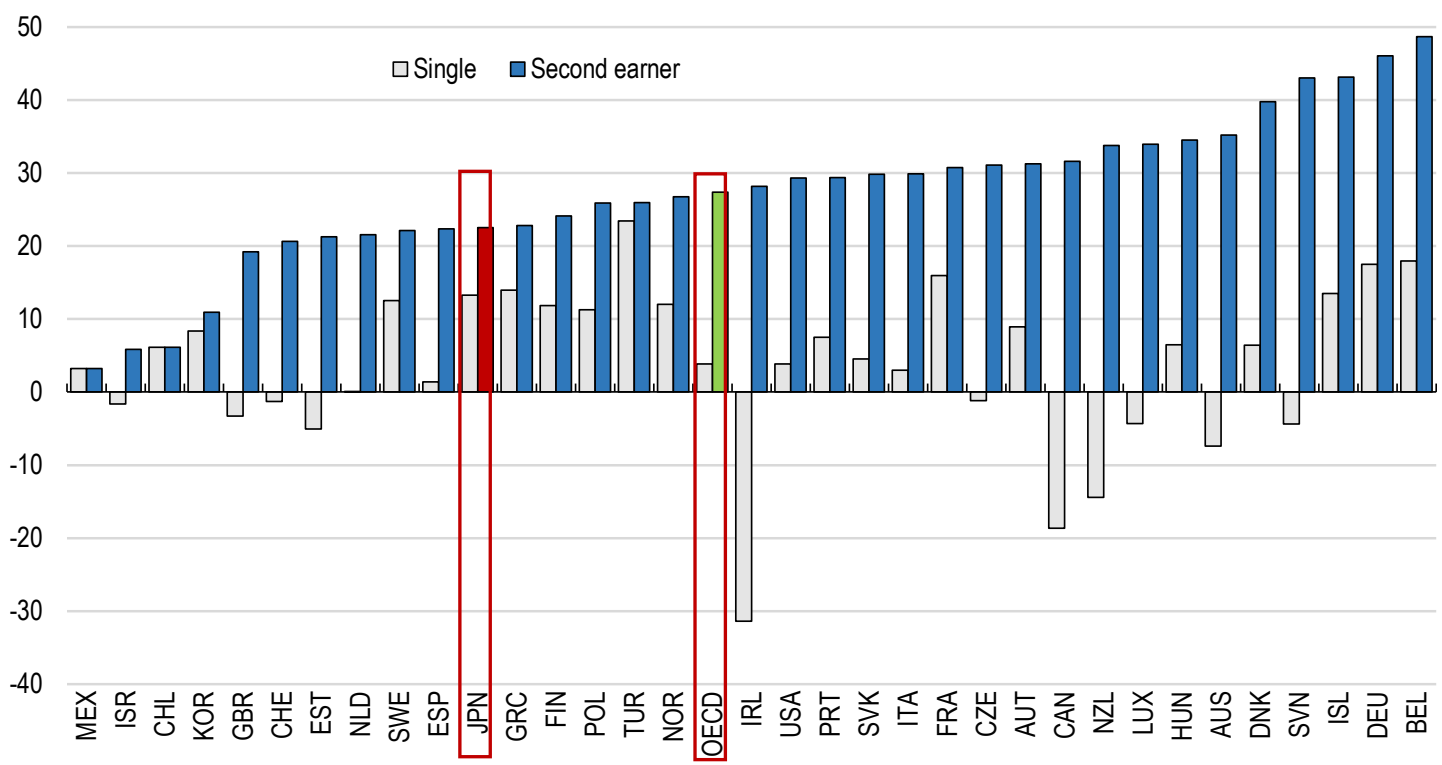

Note: In 2015. Single earner compared to second earner, both with two children and earning $67 \%$ of the average wage. The spouse of the second earner has a salary equal to the average wage.

Source: Thomas and O'Reilly (2016).

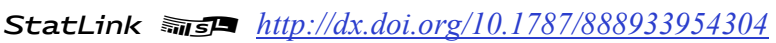

Table 5. Targets set in the 2015 Fourth Basic Plan for Gender Equality

\begin{tabular}{|c|c|c|c|}
\hline Sector & Indicator & Most recent level & Target (deadline) \\
\hline $\begin{array}{l}\text { National civil } \\
\text { service }\end{array}$ & $\begin{array}{l}\text { Share of female directors } \\
\text { Share of female section chiefs }\end{array}$ & $\begin{array}{l}4.9 \% \text { (July 2018) } \\
25.0 \% \text { (July 2018) }\end{array}$ & $\begin{array}{l}7 \% \text { (end of FY 2020) } \\
30 \% \text { (end of FY 2020) }\end{array}$ \\
\hline $\begin{array}{l}\text { Prefectural civil } \\
\text { service }\end{array}$ & $\begin{array}{l}\text { Share of female directors } \\
\text { Share of female section chiefs }\end{array}$ & $\begin{array}{l}10.5 \%(2018) \\
22.6 \%(2018)\end{array}$ & $\begin{array}{l}\text { 15\% (end of FY 2020) } \\
30 \% \text { (end of FY 2020) }\end{array}$ \\
\hline $\begin{array}{l}\text { Municipal civil } \\
\text { service }\end{array}$ & $\begin{array}{l}\text { Share of female directors } \\
\text { Share of female section chiefs }\end{array}$ & $\begin{array}{l}16.7 \%(2018) \\
34.0 \%(2018)\end{array}$ & $\begin{array}{l}20 \% \text { (end of FY 2020) } \\
35 \% \text { (end of FY 2020) }\end{array}$ \\
\hline $\begin{array}{l}\text { Private } \\
\text { corporations }\end{array}$ & $\begin{array}{l}\text { Share of female directors } \\
\text { Share of female section chiefs }\end{array}$ & $\begin{array}{l}10.9 \%(2017) \\
18.4 \%(2017)\end{array}$ & $\begin{array}{l}15 \%(2020) \\
25 \%(2020)\end{array}$ \\
\hline Total economy & Employment rate for women aged $25-44$ & $76.5 \%(2018)$ & $77 \%(2020)$ \\
\hline Total economy & $\begin{array}{c}\text { Share of workers working more than } 60 \\
\text { hours per week }\end{array}$ & $\begin{array}{l}\text { Men: } 10.56 \% \text { (2018) } \\
\text { Women: } 2.4 \%(2018)\end{array}$ & $5.0 \%(2020)$ (for men) \\
\hline $\begin{array}{l}\text { National civil } \\
\text { service }\end{array}$ & $\begin{array}{l}\text { Share of male workers who take childcare } \\
\text { leave }\end{array}$ & $10.0 \%$ (FY 2017) & $13.0 \%(2020)$ \\
\hline $\begin{array}{l}\text { Local civil } \\
\text { service }\end{array}$ & $\begin{array}{l}\text { Share of male workers who take childcare } \\
\text { leave }\end{array}$ & $3.6 \%(F Y 2016)$ & $13.0 \%(2020)$ \\
\hline Private firms & $\begin{array}{l}\text { Share of male workers who take childcare } \\
\text { leave }\end{array}$ & $5.1 \%$ (FY 2017) & $13.0 \%(2020)$ \\
\hline
\end{tabular}

Source: Cabinet Office (2018). 
Figure 25. Japanese women are under-represented in leadership positions
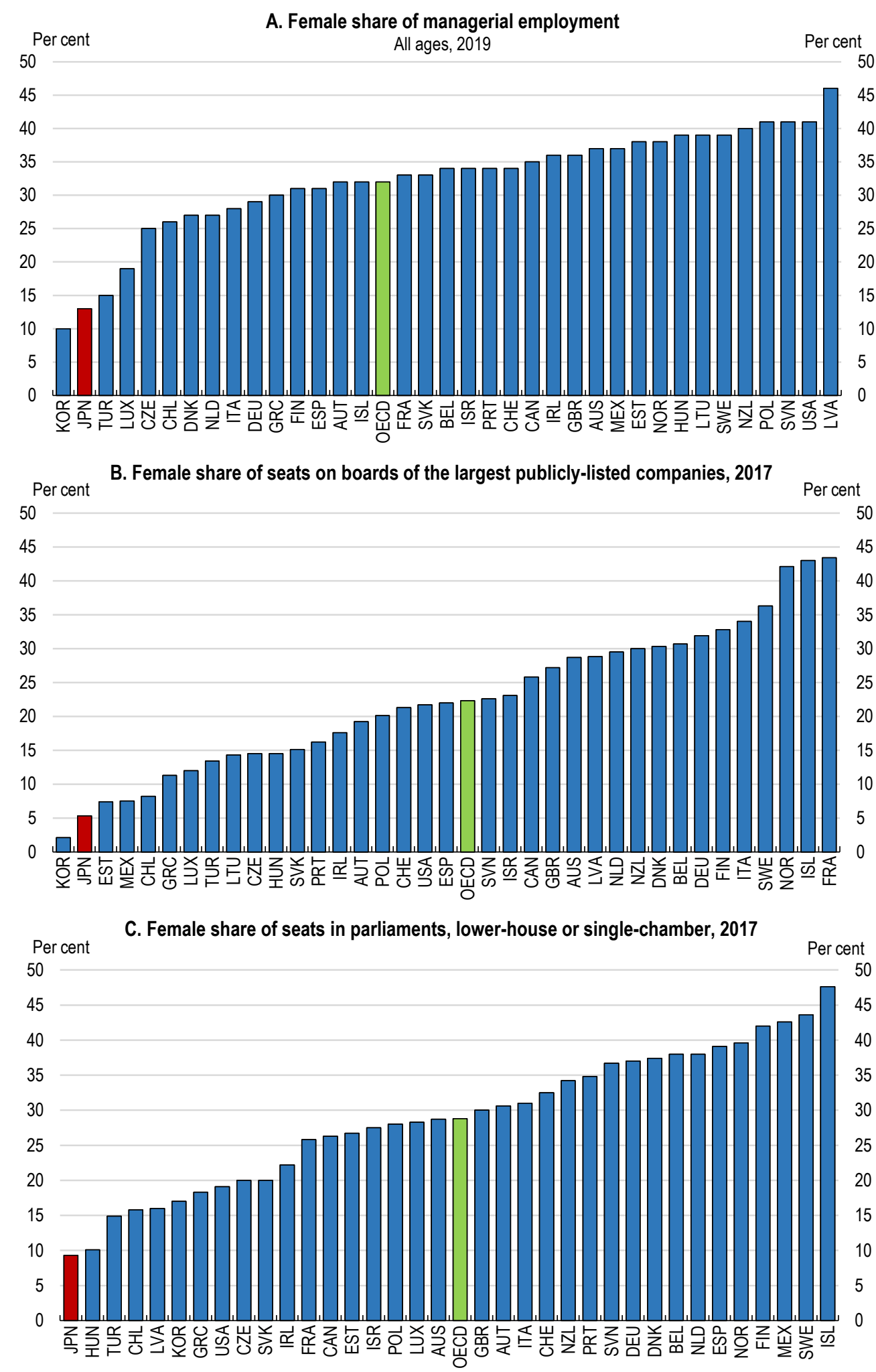

Source: OECD Gender database.

StatLink 제내 http://dx.doi.org/10.1787/888933954323 
Given the slow progress toward the $30 \%$ goal by 2020 , the Fourth Basic Plan for Gender Equality in 2015 set more realistic targets of 7\% and 15\% for women's share of management positions in the central government and private sector, respectively (Table 5). Strategies to achieve these goals include: $i$ ) reforming "male-oriented working styles"; ii) expanding women's participation in policymaking; iii) securing equal opportunities and treatment between men and women; $i v$ ) improving work-life balance; and $v$ ) promoting gender equality in a range of areas, including science and technology. Moreover, it has introduced a number of additional objectives, though none are binding and there are no penalties for failing to reach them:

- In 2015, the government set a target of raising the share of women on companies' boards of directors to $10 \%$ by 2020 .

- A 2015 law requires large companies to set targets, such as hiring and promoting women, but do not need to report on the results.

- The government has requested political parties to voluntarily set a target of raising the proportion of female candidates for the Diet to $30 \%$ by 2020 .

The low share of women in management partially reflects skills and education. Women's share of bachelor degrees granted in 2016 was $45 \%$, the lowest in the OECD and well below the $58 \%$ OECD average (OECD, 2017e). Moreover, there is a large gender gap in what students study. The share of women graduating in engineering, manufacturing and construction was the lowest in the OECD at 14\% in 2016 (Figure 26). While girls are more focused on careers in health services, boys are more interested in engineering and computing (OECD, 2016b). However, women face discrimination in the health sector. In 2018 , the government announced that three medical universities had rigged their entrance exam to increase the number of young male doctors, thus limiting the increase in the number of female doctors. Although the share of women doctors rose from $14 \%$ in 2000 to $20 \%$ in 2015, it is still far below the OECD average of $47 \%$ (Panel B).

A government survey of firms in which the share of women in employment is less than $10 \%$ identified three major reasons for the lack of female leadership. The main reason, cited by the majority of respondent companies was that, "There are no women who have the necessary knowledge, experience or judgment capability" (Yamaguchi, 2016). However, among women in the 55-59 age group who graduated from four-year universities, only around a quarter had attained a management position compared to four-fifths of men (Figure 27). Moreover, two-thirds of the men in that age group who had only graduated from high school reached management positions. In short, having as much or more education than men does not ensure equal outcomes for women.

In Japan's seniority-based system, tenure plays an important role in determining wages and promotions (Yashiro, 2014). Given that nearly half of women withdraw from the labour force when they have their first child, the average length of female employment is shorter than that of men. The other major reasons cited by firms in the survey on the lack women in management was, "Women retire before attaining management positions due to their short duration of employment" (Yamaguchi, 2016). The firms thus blamed women for their small share of management positions without any mention of discriminatory practices. 
Figure 26. Japanese women are under-represented in certain areas of study and professions A. Japanese women are under-represented in certain areas of study

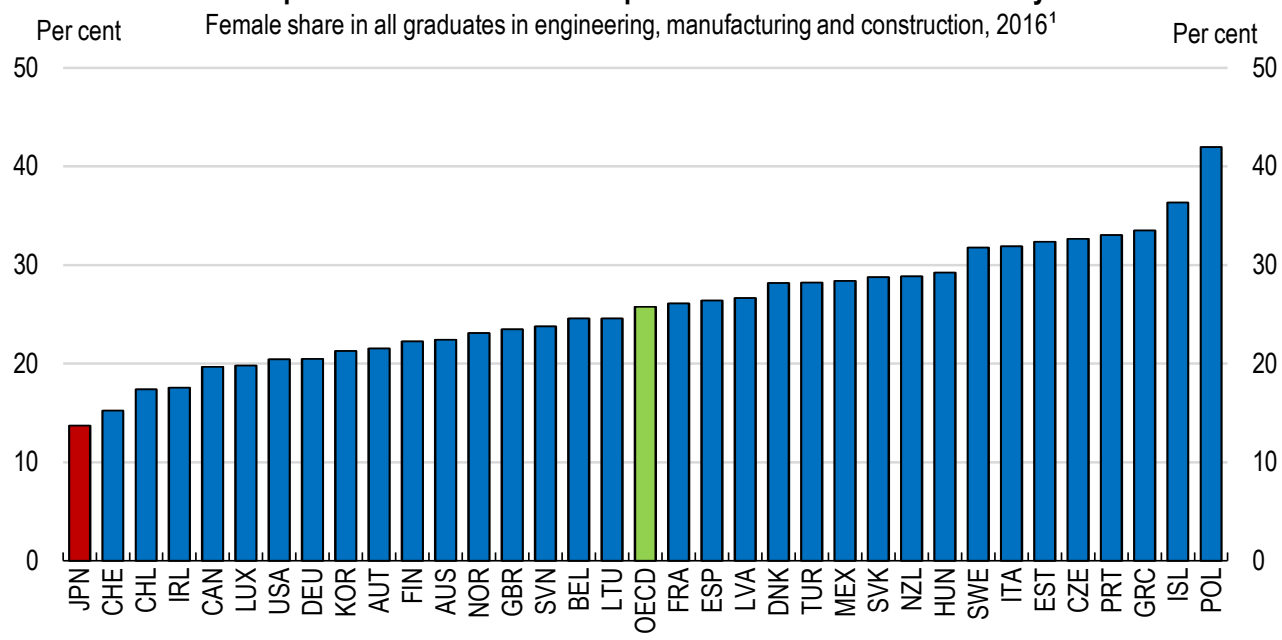

B. The share of doctors who are women in Japan is the lowest in the OECD

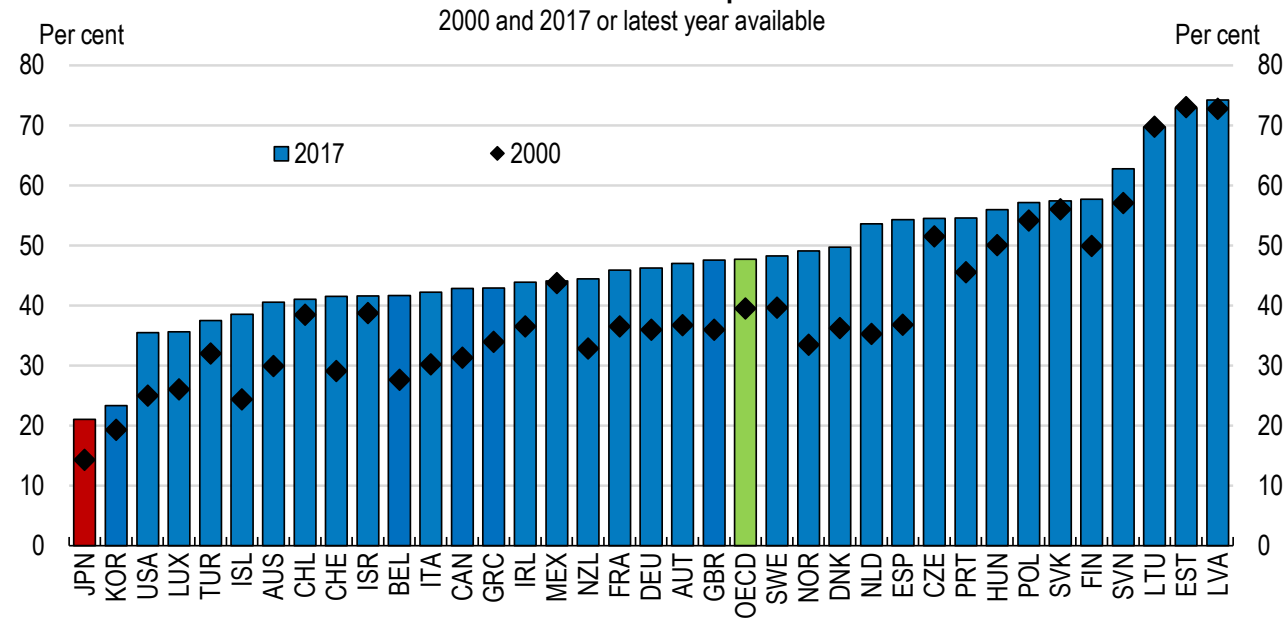

1. Percentage share of women in all tertiary graduates in these subjects in 2016.

Source: OECD Gender database.

StatLink : तiाs http://dx.doi.org/10.1787/888933954342

However, the share of workers in managerial and supervisory positions is significantly lower for women even when comparing them to men with the same length of service. Among regular, white-collar workers with 31 years or more of tenure, only $20 \%$ of women served as section heads (kacho) and above compared to $78 \%$ of men (Figure 27, Panel B). For men, the $20 \%$ share of section heads and above was reached after only 11-15 years of tenure. Similarly, $50 \%$ of women with 31 years or more of tenure reached the level of task group heads (kakaricho) and above compared to $93 \%$ for men. The disparities between the rank of men and women increase as one climbs the organisational ladder. 
Figure 27. The impact of education and tenure on the share of women in management
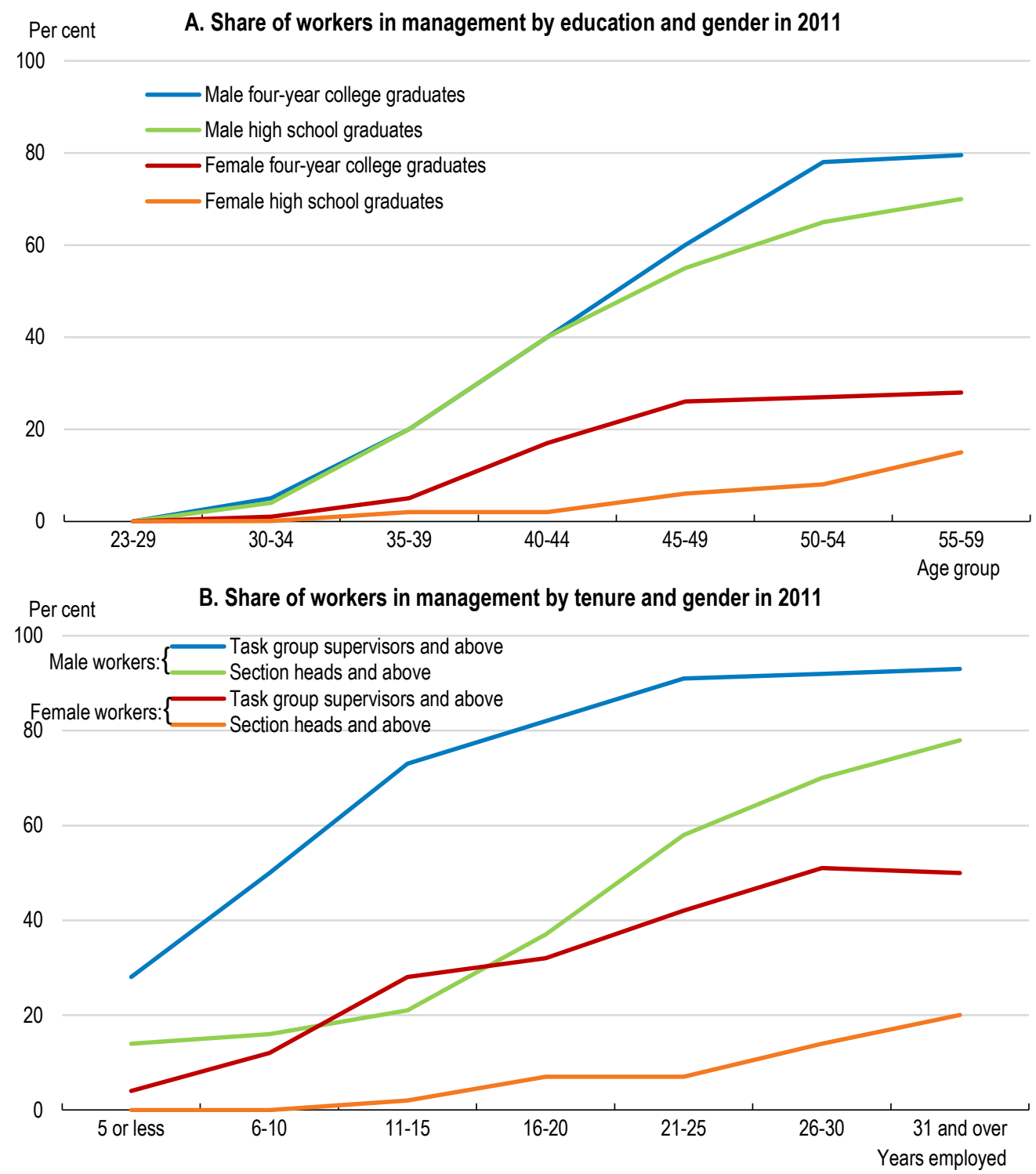

Note: Based on a sample of 6480 male employees and 3023 female employees in one of 1677 firms with 100 or more employees.

Source: Yamaguchi (2016).

StatLink त्ञाs http://dx.doi.org/10.1787/888933954361

Differences between male and female workers in education, age and tenure only explain between $20 \%$ and $30 \%$ of the gender gap in management positions (Youm and Yamaguchi, 2016). Japanese labour practices appear to explain much of the remaining inequality. Female graduates are less likely to enter regular employment and to enter fast-track career streams where workers are groomed for higher management. Track-based hiring of women (the "course system" in Japan), typically for clerical work, results in "indirect discrimination" (Yamaguchi, 2014). In addition, many employers still expect women to withdraw from the labour force around the time of childbirth and therefore are less likely to invest in on-the-job training for women to acquire skills specific to the firm. This self- 
fulfilling prophecy contributes to a very "leaky labour market pipeline" to management positions for women (Naito, 2016).

Other Japanese employment practices limit women's opportunities to reach management level. First, working long hours is a prerequisite for promotion to management. Many women with family responsibilities thus opt out of career tracks (Yamaguchi, 2016). Second, high performance evaluations increase the probability of promotion for men, but not for women (Yamaguchi, 2014). Third, regular employees are frequently shifted between jobs in the process of climbing the corporate ladder, which often requires them to relocate. Such an approach is problematic in dual-income households (Macnaughtan, 2015). As in the case of older persons, moving away from traditional labour market practices to adapt to the changing needs of a more diverse workforce is important to increase the share of women in employment and in leadership positions.

The 2006 amendment of the Act on Securing Equal Opportunity and Treatment between Men and Women in Employment aims to prohibit indirect discrimination, which consists of practices, policies or rules that apply to everyone in the same way, but have a detrimental impact on certain groups. However, the track-based hiring of women - the course system - is not regarded as indirect discrimination. In the United States, institutions or practices are considered to have an unfair impact on women if the rate for hiring or promoting women is less than $80 \%$ of the rate for men with equivalent qualifications. Moreover, statistically significant gender disparities are evidence of discrimination even when the $80 \%$ rule is not satisfied. Stronger rules against indirect discrimination in Japan would help women rise to leadership positions (Yamaguchi, 2014).

\section{Making greater use of foreign workers}

The number of foreign employees (including foreign trainees) reported by firms doubled from 0.7 million in 2013 to 1.46 million in October 2018. This reflects the willingness of employers to hire foreign workers and government policies aimed at making greater use of foreign workers. Still, they account for only about $2 \%$ of Japan's labour force, one of the lowest shares in the OECD. While foreign-born residents rose from 1.3\% of Japan's population in 2000 to $1.9 \%$ in 2017, it is still the third lowest in the OECD and well below the 13\% OECD average (Figure 28). About a third of foreign residents are KoreanJapanese, Japanese descendants (mainly from South America) and spouses of Japanese nationals. The remainder are roughly evenly divided between skilled workers, students (who may be authorised to work up to 28 hours a week), and trainees in the Technical Intern Training Programme.

Japan has admitted skilled foreigners but has limited migration for less-skilled employment and technical skills (Box 1). In December 2018, the Diet approved a new residency status for work-ready foreigners with expertise in industries that need more workers, such as construction, agriculture and long-term care. This landmark decision will allow lowerskilled workers with a certain level of knowledge and experience to be employed in Japan for the first time beginning in April 2019. The government estimates that up to 345150 foreign workers will be accepted over 2019-24 under the new residency status in 14 industries. The new status will only be available to foreigners who pass proficiency tests in the Japanese language and vocational skill exams. However, foreign trainees who have completed Technical Intern Training II will be exempted from the language and skill exams. A new language exam will be held in Vietnam, China, the Philippines, Indonesia, Thailand, Myanmar, Cambodia, Nepal and Mongolia in 2019. 
Figure 28. The share of the foreign-born population in Japan is one of the lowest in the OECD

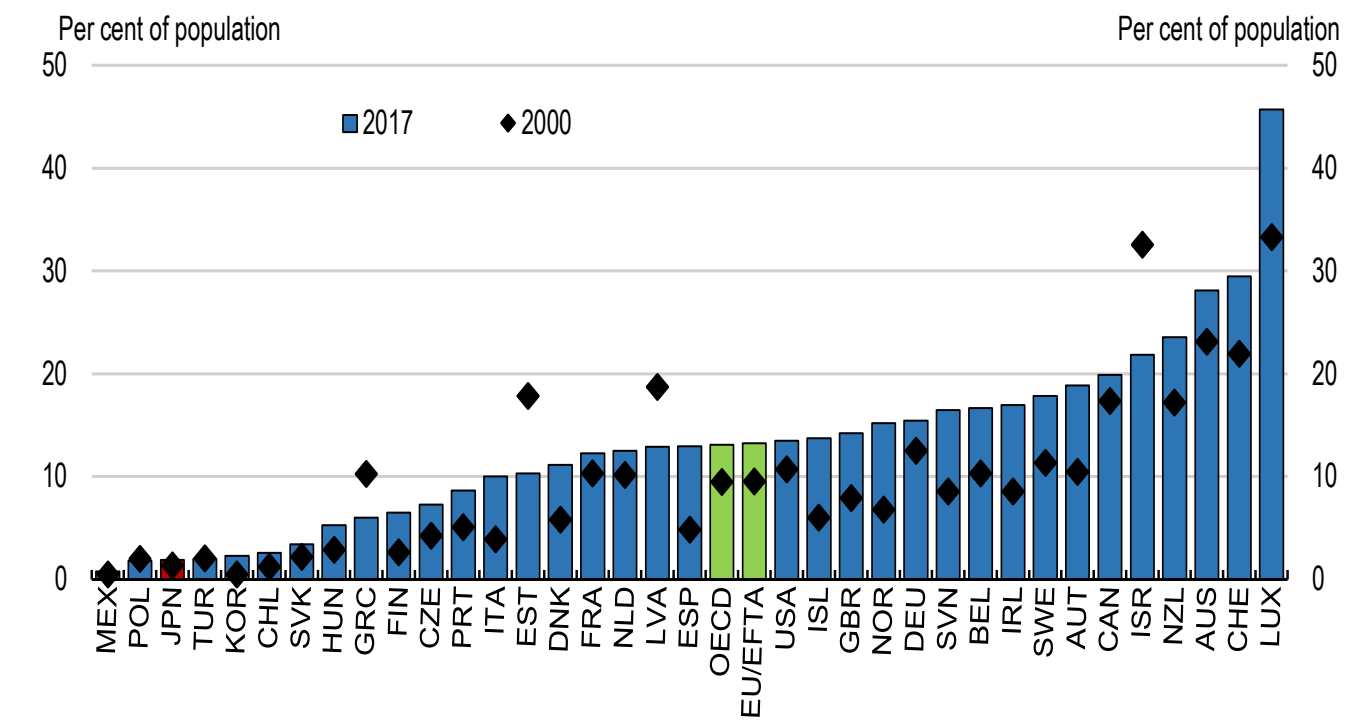

Source: OECD (2018a).

StatLink त्ञाIs http://dx.doi.org/10.1787/888933954380

The new residency status has two categories. Workers in the first category will be allowed to stay in Japan for five years, but without their family. Those in the second category, who must have higher vocational skills, will be able to renew their status of residence beyond five years and to bring their spouse and children to Japan. Foreign workers shall be paid at least as much as Japanese workers doing the same job.

It is not clear whether the policy change will lead to widespread recruitment of foreign workers by Japanese employers, who will drive the system. Moreover, employers may not be interested in expanding their hiring of foreigners even if the planned number pass the exams. Furthermore, the language exams, such as that for nursing care, may pose difficulties for candidates.

The government has stressed that the residency status is not a step towards immigration, which some fear would harm social cohesion and public safety in one of the world's most homogeneous societies. Even those in the second category under the new residency status will need to apply for an extension to stay in Japan (Burgess, 2018). International migration on a scale sufficient to substantially change Japan's demographic picture is unrealistic. To keep Japan's working-age population at its 1995 peak would require inflows of more than 0.6 million workers per year (Peng, 2016). Still, increased inflows of foreign workers in an important element of a comprehensive approach to coping with population decline. OECD research shows considerable evidence demonstrating that the medium and long-term effects of migration on public finance, economic growth and the labour market are generally positive (OECD, 2016a). Immigration can increase tax revenue and social security contributions, raise the share of the population that is working and fill some skill gaps and specific bottlenecks. 


\section{Box 1. The current framework for foreign workers in Japan}

Japan's immigration system has developed over decades through the introduction of residency status categories for specific groups. Residency statuses are based on occupational categories (such as professors and entertainers), specific programmes (such as the Technical Intern Training Programme), and overseas Japanese descendants. The result is a collection of specific occupation-based permits, in contrast to most OECD countries where admission is subject to a labour market test, education or occupational skill requirement, or salary threshold. For the skilled occupation categories, Japan requires that foreigners demonstrate the requisite skill level and meet prevailing wage requirements. Family reunification is possible, although family members' access to the labour market depends on their residency status. Application for permanent residence for skilled workers is possible after ten years. Relative to most other OECD countries, these conditions are restrictive.

To make Japan's residence system more attractive for the highest qualified, the government introduced a points-based scheme (PBS) in 2012, under which high-scoring applicants are granted more favourable conditions for family members and faster access to permanent residence. Points are given for education, occupational characteristics, language skills, income and other factors (OECD, 2018c). The measure applies to both in-country applicants and those from abroad. The uptake of the PBS was limited in the first few years and primarily involved foreigners already resident in Japan. The PBS resulted in about 8500 issuances in the first five years. The PBS was adjusted in 2017 to provide faster access to permanent residence for the highest-scoring applicants, who can acquire it after only one year. The PBS is not comparable to point-based systems in Australia, Canada and New Zealand, as it is contingent on employment in Japan and offers an initial temporary residence. The other countries use their PBS to select immigrants from a pool of candidates and grant them immediate permanent residence.

In principle, labour migration for employment in low-skilled jobs has not been allowed, although several important channels have been created to supply employers with workers in low-skilled jobs. The Technical Intern Training Programme, which dates back to the 1960s, allows foreigners to work in certain low-skill occupations. Trainees are placed by an intermediary agency with a specific employer. The Programme was extended from one year to three in 1993, and in 2017 trainees supervised by "outstanding supervisory organisations" were allowed to stay for two additional years. In 2010, coverage of the labour law was extended to first-year participants in the Programme. Around three-quarters of the 275000 trainees in 2017 were from China and Vietnam.

The stated purpose of this government-supported Programme is to promote the growth of developing countries through the transfer of skills and expertise gained by "trainees". However, some reports say that the Programme is an employment opportunity and Japanese employers have used it to find workers for low-wage jobs. Furthermore, the Programme has been criticised as susceptible to employer exploitation of the trainees and more serious abuses. A government report found that $71 \%$ of firms violated the Labour Standards Act in 2017, although this was down from 80\% in 2013 (Ministry of Health, Labour and Welfare, 2018). In 2017, the Ministry of Health, Labour and Welfare introduced regulations with penalties attached to "reduce human rights violations", stating that "trainees are no different than Japanese labourers" (Japan Times, 2017). In addition, a significant number of trainees left the companies that brought them to Japan to work without authorisation elsewhere (Menju, 2017). 
In the 1990s, Japan opened a second channel for low-skilled workers by allowing overseas Japanese descendants - up to the third generation - to come to Japan for employment or to visit family. Many Brazilians and other South Americans came to Japan, where they were employed through temporary agencies as contract workers. Unlike trainees, they also brought their families, although their children did not generally attend Japanese schools and often did not acquire Japanese language skills. About one-third of these workers of Japanese descent left in the late 2000s as manufacturing employment declined, although some have since returned. In 2017, there were about 250000 . The government has instituted a more favourable policy for this group and extended eligibility to the fourth generation.

Japan also has around 150000 foreign students enrolled in higher education, both universities and language schools. Ambitious targets to increase Japan's international student enrolment in higher education have not been met, although Japan has about $8 \%$ of global market share of international study. Students can be authorised to work up to 28 hours a week. Enforcement is difficult and some work more hours, in some cases with two jobs. Students at language and vocational schools (90 000 and 67000 respectively in 2018) in particular appear at risk of working rather than studying.

However, the benefits of foreign workers depend on their skills. Japan faces competition from other Asian economies in attracting talented foreign workers. Offering long-term residency to workers and their spouses and children and helping them cope with the challenges of moving to Japan would enable Japan attract high-quality foreign workers. In the 2015 Migrant Integration Policy Index, which ranks 38 advanced countries in eight policy areas, Japan's lowest scores were for education $\left(29^{\text {th }}\right)$ and anti-discrimination $\left(37^{\text {th }}\right)$ (Barcelona Centre for International Affairs, 2015). According to a 2017 government study, nearly $40 \%$ of foreign residents had been refused housing during the preceding five years based on their nationality (Center for Human Rights Education and Training, 2017). Realising the economic benefits of migration also requires significant investment in the education of new migrants, notably the Japanese language. The government aims to avoid the concentration of foreign workers in Tokyo, though this may make it more difficult to provide adequate support. In sum, Japan may not be able to realise the full benefits of foreign workers by relying on temporary workers.

Japan also faces challenges in retaining skilled foreign workers, many of whom are language or university teachers and business managers at multinationals. Language barriers and differences in corporate culture are barriers to attracting and retaining skilled foreign workers (ADBI-OECD-ILO, 2018). Japan also has a low retention rate for international students. Although about half intend to remain in Japan, post-graduation transition to employment is about $15 \%$. Mismatches between field of study and employer interest in international graduates partly explain this, as does the perception of Japanese firms that the main advantage of international graduates is to expand exports to their home countries (ADBI/OECD/ILO, 2015).

\section{Promoting inclusive growth by breaking down labour market dualism}

The large share of non-regular workers among young and prime-age workers has negative implications for extending employment of older persons, as non-regular workers often do not have the career progression and skills that would allow them to stay longer in the labour force. Non-regular employment, a category that includes fixed-term, part-time and dispatched workers, doubled from 9.7 million (20.3\% of total employment) in 1994 to 20.4 
million (37.3\%) in 2017. For men, non-regular employment is concentrated among those under age 35 and those over age 55 (Figure 29, Panel A). Under Japan's seniority-based wage system, firms cannot afford to keep regular workers, prompting them to impose mandatory retirement and transform regular workers to non-regular status. This shift discourages some employees from continuing to work and lowers the productivity of those who stay, as noted above. Women account for two-thirds of non-regular workers (Panel B). Of women working as employees, 55.5\% were non-regular workers in 2017, compared to only $21.9 \%$ among men. The large gender wage gap (Figure 16) is largely explained by the fact that women who leave the labour force to care for children tend to be relegated to nonregular status if they return to employment.

Figure 29. Non-regular employment is concentrated among women

Percentage employed in 2017 by type of worker
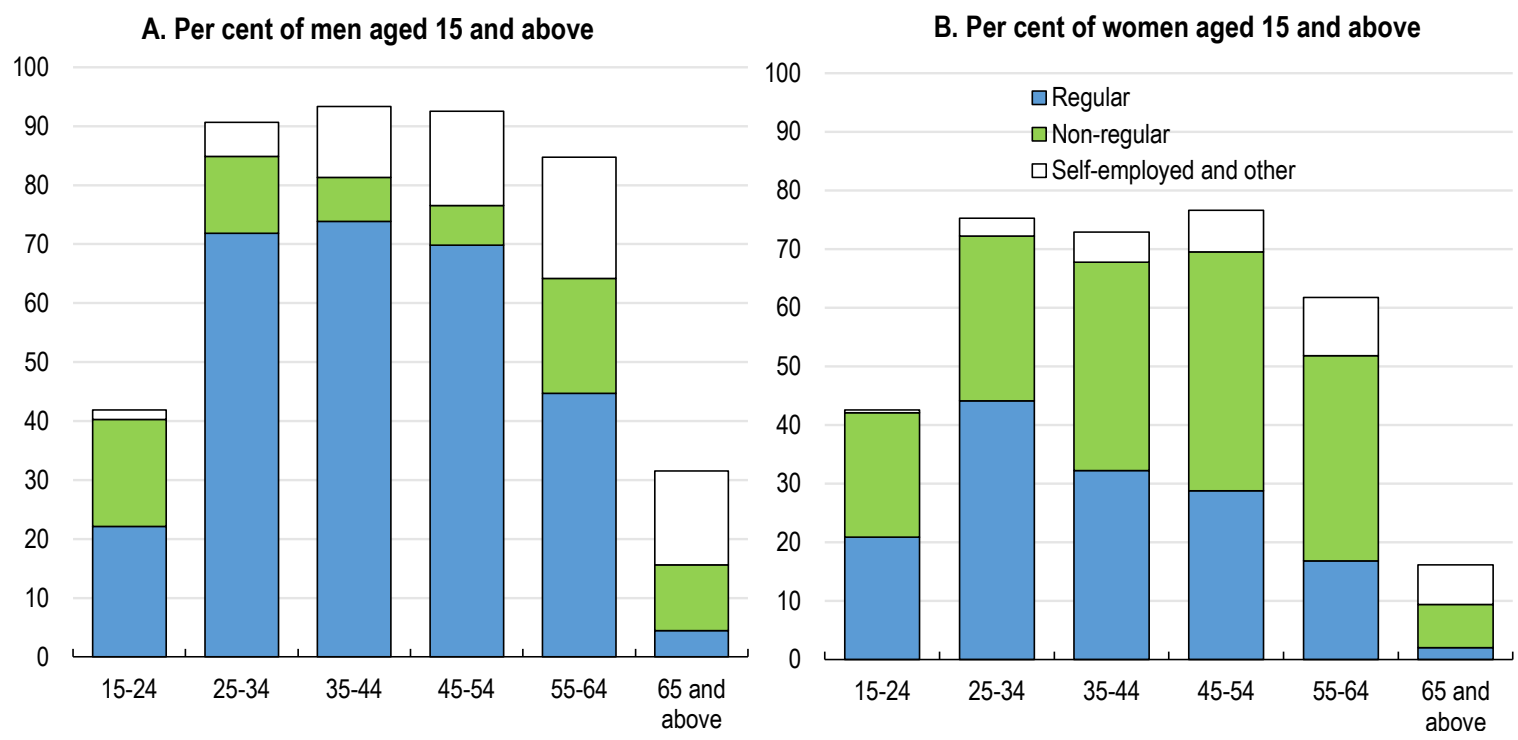

Source: Ministry of Internal Affairs and Communications, Labour Force Survey, Basic Tabulation, 2017.

StatLink 세매 http://dx.doi.org/10.1787/888933954399

Dualism undermines productivity, as non-regular workers receive less training from firms, which have little incentive to invest in workers who are not permanent. Studies of other countries find that dualism results in less human capital and lowers productivity growth (Aoyagi and Ganelli, 2013). Low-quality jobs are detrimental to well-being. Dualism also worsens inequality and poverty due to wide wage gaps. On an hourly basis, non-regular workers earn around $60 \%$ as much as regular workers. The wage gap increases with age; in the 50-54 age group, regular workers earn twice as much as non-regular workers (Figure 30). This comparison understates the gap as it excludes bonus payments, which most nonregular workers do not receive. Low pay for non-regular workers results in high relative poverty rates. Among households with one earner, the poverty rate is $5 \%$ if the husband is a regular worker and $35 \%$ if he is a non-regular worker (OECD, 2017b). The negative consequences of dualism are exacerbated by limited mobility in a segmented labour market, in contrast to many other OECD countries, where temporary work is frequently a stepping stone to permanent employment. 
Figure 30. The wage gap between regular and non-regular workers is large

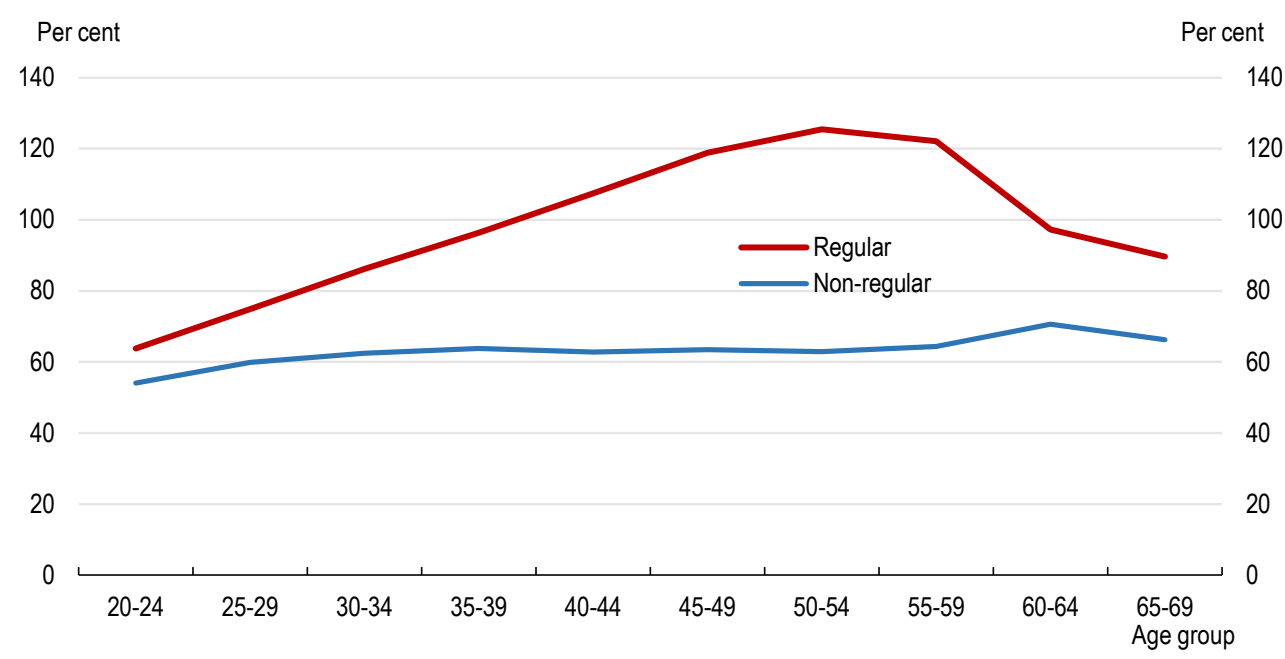

Note: Hourly wage in June 2015, excluding overtime payments and bonuses. Only $30 \%$ of part-time workers, who account for $70 \%$ of non-regular employment, receive bonus payments so the pay gap is even larger. Source: Ministry of Health, Labour and Welfare, Basic Survey on Wage Structure 2015.

StatLink 세매 http://dx.doi.org/10.1787/888933954418

Breaking down labour market dualism is essential to boost productivity and achieve inclusive growth. Prime Minister Abe said that his goal is "to eliminate the expression "nonregular workers'" (Prime Minister's Office, 2016). The "equal pay for equal work" principle introduced in 2018 intends to resolve irrational gaps in the working conditions between regular and most types of non-regular workers in the same firm. The fundamental objective is that everyone be treated fairly whatever their employment status. A guideline to accomplish equal pay for equal work was announced in December 2018. The decision on whether a practice is irrational will be determined by judicial decisions. The new law will take effect in 2020 (2021 for fixed-term and part-time workers in SMEs).

Introducing the principle of equal pay for equal work is challenging, as it requires employers to evaluate workers objectively and fairly. Changing the way that employers assess workers creates costs for both employers and employees. In 2018, the Ministry of Health, Labour and Welfare introduced a subsidy of JPY 0.5 million (USD 4 433) to SMEs that set up a wage system that is based on workers' vocational ability rather than regular and automatic pay raises. Firms can receive a second subsidy of JPY 0.8 million if their staff turnover rate declines by 1 percentage point, total wage costs increase by $2 \%$ after one year and labour productivity rises by $6 \%$ three years after their initial application. Although there are no data available on the take-up of this subsidy, the current design may discourage firms' participation, as they have to wait three years for a small payment that does little to offset a $2 \%$ rise in wage costs. Moreover, the preparation of the application for the subsidy is burdensome and complicated (OECD, 2018f).

Moreover, it is difficult in practice for workers, given their limited information, the ambiguity of job assignments and the lack of transparency about pay, to take complaints of unfair treatment to the judicial system. Moreover, few OECD countries have laws that explicitly require that temporary workers be paid the same wages as equivalent permanent workers, given the difficulty of proving that their treatment is discriminatory (OECD, 2016c). To enable workers to make complaints of unfair treatment, Japan needs more transparency about pay. In many OECD countries, companies are increasingly required to 
carry out analyses of gender wage gaps, and are requested or required to share this information with employees, government auditors, or the public (OECD, 2018e). In Japan, the revised laws for equal pay for equal work oblige employers to explain, upon request from non-regular workers, how and on what grounds the treatment of non-regular workers is different from that of regular workers and expand administrative measures for enforcement and Alternative Dispute Resolution by the government. These measures can contribute to strengthening firms' accountability for discriminatory treatment of their employees. In addition, reducing the weight given to seniority in setting wages would support the principle of equal pay for equal work, as noted above. Nevertheless, enforcement of the equal pay for equal work is still challenging.

While laws to end discrimination are always welcome, breaking down dualism requires addressing the factors that encourage firms to hire non-regular workers, notably lower labour costs and greater employment flexibility. In addition to lower pay, non-regular workers receive less coverage by social security, which reduces employer social insurance contributions. Around a third of non-regular workers are not covered by employment insurance and about half are excluded from the EPI and firm-based health insurance. In addition, $70 \%$ of part-timers do not receive bonus payments and $90 \%$ do not receive the lump-sum retirement benefit paid by firms.

Firms also hire non-regular workers to increase employment flexibility due to the employment protection accorded to regular workers. The index of protection of permanent workers against individual dismissals in Japan is above the OECD average, mainly due to the requirements for maximum time for claim, length of trial and protection against unjustified and unfair dismissals (difficulty of dismissal) (Figure 31). According to the Global Competitiveness Index, restrictions on hiring and firing of workers in Japan is ranked as the tenth most severe among OECD countries (World Economic Forum, 2017). Japan's Labour Contract Act states that any dismissal of workers that "lacks objective, reasonable grounds and is not considered to be appropriate in general societal terms, [shall] be treated as an abuse of power and be invalid". This very general formulation allows the legal system considerable discretion in applying the law. Judicial precedents have established four criteria to determine whether employment adjustment as a result of corporate downsizing can be deemed an abuse of power by the employer:

- The employer must establish the economic necessity for reducing its workforce.

- The firm must demonstrate that it made all reasonable efforts to avoid dismissals (i.e. reducing overtime hours, re-assigning or seconding staff, offering voluntary retirement packages).

- The employer must establish reasonable and objective criteria for selecting which workers will be dismissed.

- The employer must show that the overall dismissal procedure is acceptable, for example by showing that unions or worker representatives were consulted.

It is "exceedingly difficult to judge the validity of dismissal" (JETRO, 2016), as these criteria leave considerable room for interpretation (OECD, 2015a). If an employer is judged to fall short of any of the four criteria, the dismissal may be rendered invalid. The court usually orders reinstatement of dismissed workers with back pay. There is no time limit on when former workers may claim unfair dismissal. In sum, employers face great uncertainty in trying to dismiss regular workers, thus prompting them to turn to non-regular workers. 
Figure 31. Japan has relatively strong employment protection for regular workers

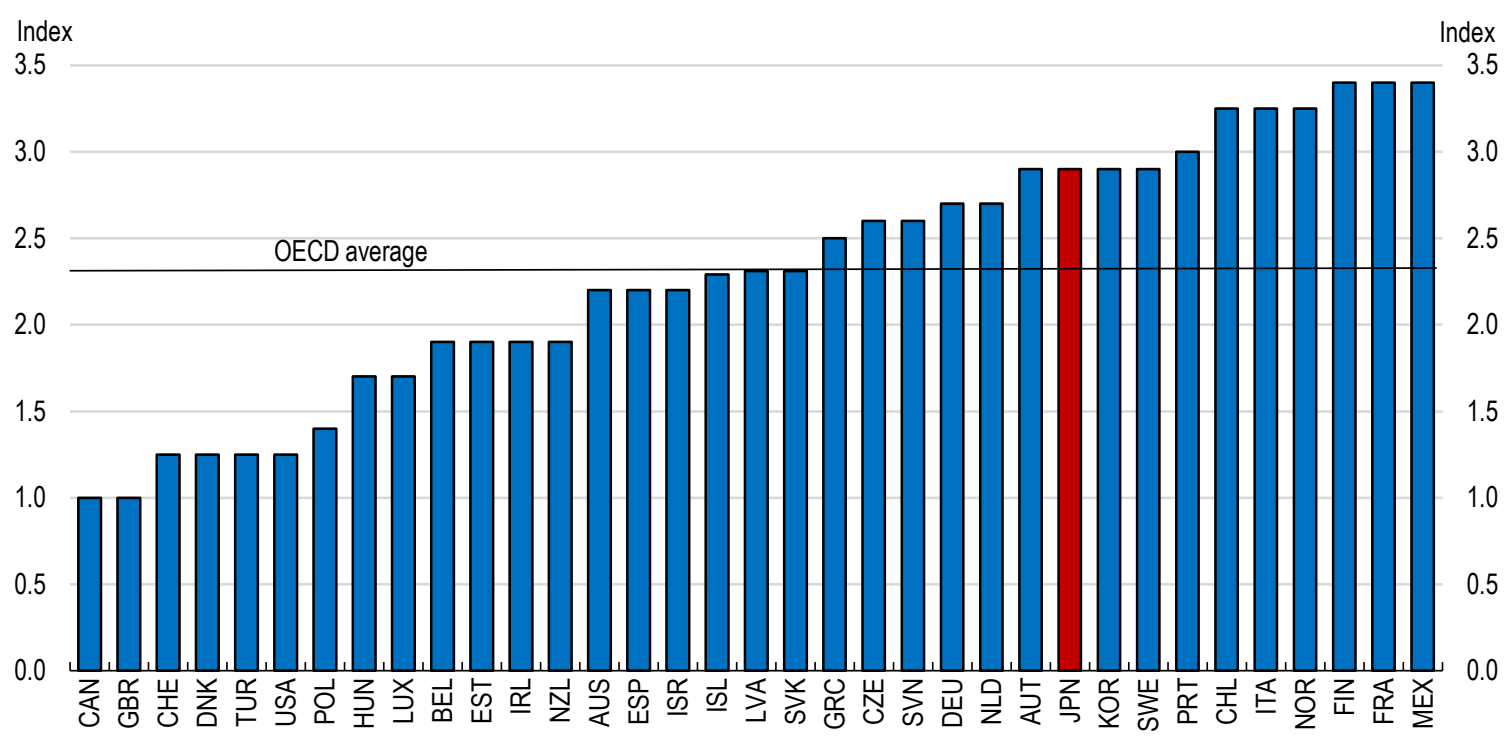

Note: The employment protection index ranges from 0 to 6 , with six being the most restrictive. Source: OECD Employment Protection database.

StatLink ज्ञाज्ञ http://dx.doi.org/10.1787/888933954437

Against this backdrop, a comprehensive strategy is needed to break down labour market dualism by increasing the coverage of social insurance and upgrading training programmes for non-regular workers, raising the minimum wage and reducing employment protection for regular workers, in part by increasing transparency (2017 OECD Economic Survey of Japan). Reducing employment protection would also promote growth-enhancing labour mobility and economic dynamism more generally (OECD, 2015b). Another OECD study shows that relaxing employment protection results in greater job reallocation across sectors, which leads to higher productivity (Cournède et al., 2016). In addition, employment flexibility has been found to encourage firms to introduce digitalisation and other key technology (Andrews et al., 2018). The 2018 OECD Job Strategy states that, "Flexibility in product and labour markets is essential to create high-quality jobs in an ever more dynamic environment" (OECD, 2018b).

As a first step to reducing uncertainty, the government should set specific monetary compensation for dismissed workers in order to achieve its goal of a "highly foreseeable dispute settlement system". In addition, employment protection for regular workers should be reduced, although this is difficult to implement in practice. In some European countries, it has been achieved through grandfathering - allowing current workers to keep current levels of employment protection but not newly-hired workers (OECD, 2017a). Another option would be to compensate regular workers for a reduction in employment protection through reforms that also accomplish the goal of improving work-life balance. For example, regular workers could be given additional leave, the right to refuse involuntary relocations and a reduction in overtime work. Finally, as part of a strategy of protecting workers rather than jobs, the government must ensure adequate income and re-employment support to displaced workers. 


\section{Main policy recommendations to meet labour market challenges in a rapidly ageing society}

\section{Key recommendations}

- Abolish the right of firms to set a mandatory retirement age and reinforce legislation against age discrimination.

- Strictly enforce the 360-hour annual limit on overtime hours that is being introduced in 2019-20 and ensure adequate penalties on firms that exceed it.

- Introduce a mandatory minimum period of rest between periods of work.

- Focus on reducing the waiting list for childcare by expanding capacity so that mothers are not forced to leave the work force.

- Strengthen measures to prevent discrimination against women in education and employment, including policies to stop indirect discrimination.

- Provide programmes to help foreign nationals adjust to Japan, including through education and language training, and ensure fair treatment in wages and conditions to attract foreign workers.

\section{Other recommendations}

- Raise the pension eligibility age above 65 to strengthen work incentives and reduce elderly poverty.

- Phase out the earnings test to encourage employment by older persons eligible for a pension.

- Break down dualism through a comprehensive strategy to reduce employment protection for regular workers, in part by setting clear rules on dismissal of workers, and expanding social insurance coverage and training for non-regular workers.

- Flatten the seniority wage curve by enforcing the equal pay for equal work provision in the work style reform.

- Improve lifelong learning by making it more relevant, including for older workers, and addressing the time and financial constraints that limit participation.

- Closely monitor the scheme that exempts skilled professional workers from overtime regulation to avoid excessive working hours.

- Reform tax-benefit systems so that both parents have broadly similar financial incentives to work.

- Increase awareness of long-term care leave entitlements among companies and workers and provide incentives to promote its use so fewer workers leave their jobs to care for elderly relatives.

- Amend the 2015 law that requires large companies to set targets for hiring and promoting women and to report on the results to include smaller companies. 


\section{Bibliography}

ADBI/OECD/ILO (2015), Building Human Capital through Labor Migration in Asia, Tokyo, http://www.oecd.org/els/mig/building-human-capital.pdf.

ADBI/OECD/ILO (2018), Labor Migration in Asia: Increasing the Development Impact of Migration through Finance and Technology, Asian Development Bank Institute, Tokyo, https://doi.org/10.1787/9789264289642-en.

Andrews, D., G. Nicoletti and C. Timiliotis (2018), "Going Digital: What Determines Technology Diffusion Among Firms?" OECD Economics Department Working Papers, No. 1466, OECD Publishing, Paris.

Aoyagi, C. and G. Ganelli (2013), "The Path to Higher Growth: Does Revamping Japan's Dual Labor Market Matter?", IMF Working Papers, No. WP/13/202, International Monetary Fund, Washington, DC.

Barcelona Centre for International Affairs (2015), Migrant Integration Policy Index 2015, http://www.mipex.eu/.

Bechichi, N. et al. (2018), "Moving Between Jobs: An Analysis of Occupation Distances and Skill Needs", OECD Science, Technology and Industry Policy Papers, No. 52, OECD Publishing, Paris, https://doi.org/10.1787/d35017ee-en.

Burgess, C. (2018), "Genuine Immigration Reform Still Alien to Japan”, East Asia Forum, 15 November, http://www.eastasiaforum.org/2018/11/15/genuine-immigration-still-alien-to-japan/.

Cabinet Secretariat (2017), "Council for Designing 100-Year Life Society", 11 September, https://japan.kantei.go.jp/97_abe/actions/201709/11article5.html.

Cabinet Secretariat (2018), Results of the FY 2017 Survey of Teleworking by National Government Employees (summary), 14 June, Government of Japan, Tokyo (in Japanese), https://www.cas.go.jp/jp/gaiyou/jimu/jinjikyoku/w_lifebalance/dai12/bessi2.pdf.

Cabinet Office (2018), Men and Women in Japan, Tokyo, http://www.gender.go.jp/english_contents/pr_act/pub/pamphlet/women-and-men18/index.html.

Center for Human Rights Education and Training (2017), Analytical Report of the Foreign Residents Survey - Revised Edition, report commissioned by the Ministry of Justice, http://www.moj.go.jp/content/001249011.pdf.

Clark, R. and N. Ogawa (1992), "The Effect of Mandatory Retirement on Earnings Profiles in Japan", Industrial and Labor Relations Review, Vol. 45, No. 2, https://www.jstor.org/stable/pdf/2524833.pdf.

Cournède, B., O. Denk, P. Garda and P. Hoeller (2016), "Enhancing Economic Flexibility: What Is in it for Workers", OECD Economic Policy Papers, No. 19, OECD Publishing, Paris.

Frey, C. and M. Osborne (2017), "The Future of Employment: How Susceptible are Jobs to Computerisation?", Technological Forecasting and Social Change, Vol. 114.

Gal. P., G. Nicoletti, T. Renault, S. Sorbe and C. Timiliotis (2019), "Digitalisation and Productivity : In Search of the Holy Grail - Firm-level Empirical Evidence from EU Countries", OECD Economics Department Working Papers, No. 1533, OECD Publishing, Paris.

Government of Japan (2018), Basic Outlook and Key Strategies, Tokyo.

Gratton, L. and A. Scott (2017), The 100-Year Life, Bloomsbury Information, London. 
Grigoli, F., Z. Koczan and P. Tapalova (2018), “A Cohort-Based Analysis of Labour Force Participation for Advanced Economies", IMF Working Papers, No. 18/120, International Monetary Fund, Washington, DC.

Guillemette, Y., C. Geppert, H. Morgavi and D. Turner (2019), "Labour Supply of Older People in Advanced Economies: What Role for Policies?", OECD Economics Department Working Papers, No. 1554, OECD Publishing, Paris.

Ikeda, S. (2017), "Family Care Leave and Job Quitting Due to Caregiving: Focus on the Need for LongTerm Leave", Japan Labor Review, Vol. 14, No. 1.

Japan Institute for Labour Policy and Training (2015), Survey on Employment and Life for Aged 60s, Tokyo, https://www.jil.go.jp/institute/research/2015/documents/0135.pdf.

Japan Institute for Labour Policy and Training (2016), Survey of the Employment of the Elderly, Tokyo, https://www.jil.go.jp/institute/research/2016/documents/156.pdf.

Japan Times (2017), "With New Rules, Japan Looks to Wipe Out Abuse in Trainee System - But Critics Say More Must Be Done", 1 November.

Japan Times (2018), “Japan's Buzzwords of the Year Nominees Reflect Myriad Influences”, 7 November.

JETRO (2016), Investing in Japan, Tokyo, www.jetro.go.jp/en/invest/setting_up/laws/section4/page8.html.

Jones, R. (2011), “Education Reform in Japan”, OECD Economics Department Working Papers, No. 888, OECD Publishing, Paris, https://doi.org/10.1787/5kg58z7g95np-en.

Jones, R. and H. Seitani (2019), "Meeting Fiscal Challenges in Japan's Rapidly Ageing Society", OECD Economics Department Working Papers, (forthcoming), OECD Publishing, Paris.

Kondo, A. and H. Shigeoka (2017), "The Effectiveness of Demand-side Government Intervention to Promote Elderly Employment: Evidence from Japan", Industrial and Labor Relations Review, http://dx.doi.org/10.1177/0019793916676490.

Macnaughtan, H. (2015), "Is Abe's Womenomics Working?", East Asia Forum, 27 August, http://www.eastasiaforum.org/2015/08/27/is-abes-womenomics-working/.

Mainichi Newspaper (201), "Angry Working Parents Turn to Social Media after Day Care Center Rejection", 6 February.

Martinez, A. (2018), "The Bankruptcy Rate due to the Worker Shortage Rises for the Third Consecutive Year", 11 July, https://izanau.com/article/view/bankruptcy-workers-shortage-rises-third-consecutiveyear.

Menju, T. (2017), "Immigration the Solution to Japan's Population Problem", East Asia Forum, 26 October, http://www.eastasiaforum.org/2017/10/26/immigration-the-solution-to-japans-populationproblem/.

Ministry of Health, Labour and Welfare (2013), Comprehensive Survey on Working Hours (in Japanese), Tokyo.

Ministry of Health, Labour and Welfare (2014), Summaries of the 2014 Actuarial Valuation and Reform Options, https://www.mhlw.go.jp/file/06-Seisakujouhou-12500000-

Benkinkyoku/2014_Actuarial_Valuatin_3.pdf.

Ministry of Health, Labour and Welfare (2017a), General Survey on Working Conditions, 2017, Tokyo.

Ministry of Health, Labour and Welfare (2017b), White Paper on Measures to Prevent Karoshi, FY 2016, Tokyo. 
Ministry of Health, Labour and Welfare (2018), The Situation of Supervision Guidance, Inspections, etc of Trainers of Foreign Technical Intern Trainees in 2017, Tokyo (in Japanese), https://www.mhlw.go.jp/stf/houdou/0000212372.html.

Miyamoto, H. (2016), "Reforming Japan's Dual Labour Market", East Asia Forum, 23 December, http://www.eastasiaforum.org/2016/12/23/reforming-japans-dual-labour-market/.

Nagamachi, R. and K. Yugami (2015), "The Consistency of Japanese Statistics on Working Hours, and an Analysis of Household Working Hours", Public Policy Review, Vol. 11/4, https://ideas.repec.org/a/mof/journl/ppr030f.html.

Naito, J. (2016), “The Self-fulfilling Prophecy in Statistical Gender Discrimination: Its Basic Mechanism and the Effects of Diversity Policies", Sociological Theory and Methods, Vol. 30, No. 1 (in Japanese), https://www.jstage.jst.go.jp/article/ojjams/30/1/30_15/_pdf.

Nedelkosta, L. and G. Quintini (2018), “Automation, Skills Use and Training”, OECD Social Employment and Migration Working Papers, No. 202, OECD Publishing, Paris.

Nemoto, K. (2016), Too Few Women at the Top: The Persistence of Inequality in Japan, Cornell University Press, Ithaca.

OECD (2011), OECD Economic Survey of Japan, OECD Publishing, Paris.

OECD (2013a), OECD Economic Survey of Japan, OECD Publishing, Paris.

OECD (2013b), OECD Recommendation of the Council on Gender Equality in Education, Employment and Entrepreneurship, OECD Publishing, Paris, https://doi.org/10.1787/9789264279391-en.

OECD (2015a), Back to Work: Japan: Improving the Re-employment Prospects of Displaced Workers, OECD Publishing, Paris, http://dx.doi.org/10.1787/9789264227200-en.

OECD (2015b), Future of Productivity, OECD Publishing, Paris.

OECD (2015c), OECD Economic Survey of Japan, OECD Publishing, Paris.

OECD (2016a), International Migration Outlook, OECD Publishing, Paris.

OECD (2016b), "Japan: Boosting Growth and Well-being in an Ageing Society", Better Policies Series, OECD Publishing, Paris.

OECD (2016c), OECD Economic Survey of Korea, OECD Publishing, Paris.

OECD (2016d), "Parental Leave: Where are the Fathers?", OECD Policy Brief, OECD Publishing, Paris.

OECD (2017a), OECD Economic Survey of Italy, OECD Publishing, Paris.

OECD (2017b), OECD Economic Survey of Japan, OECD Publishing, Paris.

OECD (2017c), Pensions at a Glance 2017: OECD and G20 Indicators, OECD Publishing, Paris.

OECD (2017d), The Next Production Revolution: Implications for Governments and Business, OECD Publishing, Paris, DOI:https://dx.doi.org/10.1787/9789264271036-en.

OECD (2017e), The Pursuit of Gender Equality - an Uphill Battle, OECD Publishing, Paris.

OECD (2018a), Education Policy in Japan: Building Bridges towards 2030, Reviews of National Policies for Education, OECD Publishing, Paris, https://doi.org/10.1787/9789264302402-en.

OECD (2018b), Good Jobs for All in a Changing World of Work; the OECD Jobs Strategy, OECD Publishing, Paris.

OECD (2018c), International Migration Outlook, OECD Publishing, Paris. 
OECD (2018d), "Japan: Promoting Inclusive Growth for an Ageing Society", Better Policies Series, OECD Publishing, Paris, https://doi.org/10.1787/9789264299207-en.

OECD (2018e), Recommendation of the Council on Ageing and Employment Policies, Paris, https://legalinstruments.oecd.org/public/doc/333/333.en.pdf.

OECD (2018f), Working Better with Age: Japan, OECD Publishing, Paris.

OECD (2019), OECD Economic Survey of Japan, OECD Publishing, Paris.

Oshio, T., A. Oishi and S. Shimizutani (2011), "Social Security Reforms and Labor Force Participation of the Elderly in Japan", Japanese Economic Review, Vol. 62, No. 2.

Oshio, T., E. Usui and S. Shimizutani (2018), "Labor Force Participation of the Elderly in Japan", National Bureau of Economic Research Working Papers, No. 24614.

Peng, I. (2016), "Japan and its Immigration Policies are Growing Old", East Asia Forum, 7 June, http://www.eastasiaforum.org/2016/06/07/japan-and-its-immigration-policies-are-growing-old/.

Prime Minister's Office (2016), "Press Conference by Prime Minister Shinzo Abe", 3 August, http://japan.kantei.go.jp/97_abe/statement/201608/1218775_11013.html.

Reuters (2017), "Japanese Companies Struggle to Hire, Retain Staff as Labor Shortages Worsen”, 3 October.

Seike, A. (2015), “Japan’s Race Against the Ageing Clock", East Asia Forum, 3 May.

Takayama, N., 2013), "Closing the Gap between the Retirement Age and the Normal Pensionable Age in Japan”, CIS Discussion Paper Series, No. 583, Center for Intergenerational Studies, Institute of Economic Research, Hitotsubashi University.

Thomas, A. and P. O'Reilly (2016), "The Impact of Tax and Benefit Systems on the Workforce Participation Incentives of Women", OECD Taxation Working Papers, No. 29, OECD Publishing, Paris, http://dx.doi.org/10.1787/d950acfc-en.

Unayama, T. (2017), "Can Childcare Waiting Lists be Eliminated? Raising Childcare Fees Seems to be a Realistic Option", Research Institute of Economy, Trade and Industry, Tokyo, https://www.rieti.go.jp/en/papers/contribution/unayama/03.html.

Usui, E., S. Shimizutani and T. Oshio (2016), "Health Capacity to Work at Older Age: Evidence from Japan", National Bureau of Economic Research Working Paper, No. 21971.

Weathers, (2016), "Child Care in Japan: The Changing Political Context", mimeo, https://core.ac.uk/download/pdf/45287040.pdf.

Yamaguchi, K. (2014), "Japan Should Introduce Legislation to Prohibit Indirect Gender Discrimination at the Workplace as a Step Toward the Greater Utilization of Women", RIETI Report, Research Institute of Economy, Trade and Industry, Tokyo.

Yamaguchi, K. (2016), "Determinants of the Gender Gap in the Proportion of Managers among WhiteCollar Regular Workers in Japan", Japan Labor Review, Vol. 13, No. 3.

Yashiro, N. (2014), "Why "Womenomics" is the Way Forward for Japan", East Asia Forum, 2 February, http://www.eastasiaforum.org/2014/10/22/why-womenomics-is-the-way-forward-for-japan/.

Yashiro, N. (2016), "Regulatory Coherence: The Case of Japan", in D. Gill and P. Intal, Jr. (eds.), The Development of Regulatory Management Systems in East Asia: Country Studies, RIA Research Project Report, 2015-4, Economic Research Institute for Asian and East Asia, Jakarta. 
Youm, Y. and K. Yamaguchi (2016), "Gender Gaps in Japan and Korea: A Comparative Study on the Rates of Promotion", RIETI Discussion Paper Series, 16-E-011, Research Institute of Economy, Trade and Industry, Tokyo. 